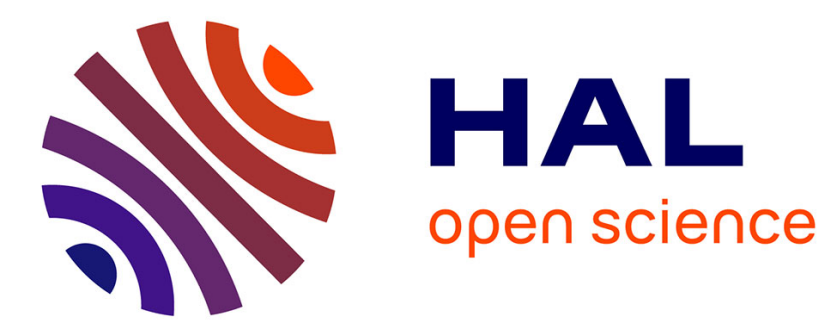

\title{
Excess control rights, bank capital structure adjustment and lending
}

Laetitia Lepetit, Amine Tarazi, Nadia Zedek

\section{To cite this version:}

Laetitia Lepetit, Amine Tarazi, Nadia Zedek. Excess control rights, bank capital structure adjustment and lending. 2013. hal-00967892

\section{HAL Id: hal-00967892 \\ https://hal-unilim.archives-ouvertes.fr/hal-00967892}

Preprint submitted on 31 Mar 2014

HAL is a multi-disciplinary open access archive for the deposit and dissemination of scientific research documents, whether they are published or not. The documents may come from teaching and research institutions in France or abroad, or from public or private research centers.
L'archive ouverte pluridisciplinaire HAL, est destinée au dépôt et à la diffusion de documents scientifiques de niveau recherche, publiés ou non, émanant des établissements d'enseignement et de recherche français ou étrangers, des laboratoires publics ou privés. 


\title{
Excess control rights, bank capital structure adjustment and lending
}

\author{
Laetitia Lepetit $^{\mathrm{a}}$, Amine Tarazi ${ }^{\mathrm{a}}{ }^{\dagger}$, Nadia Zedek $^{\mathrm{a}}$ \\ ${ }^{a}$ Université de Limoges, LAPE, 5 rue Félix Eboué, 87031 Limoges Cedex, France
}

\begin{abstract}
We investigate whether excess control rights of ultimate owners in pyramids affect banks' adjustment to their target capital ratio. When ultimate control rights and cash-flow rights are identical, banks increase their capital ratio by issuing equity and by reshuffling their assets without slowing their lending. However, when control rights exceed cash-flow rights, banks are reluctant to issue equity to increase their capital ratio and, instead, shrink their assets by mainly cutting their lending. A deeper investigation shows that this behavior is only apparent in family-controlled banks and in countries with relatively weak shareholder protection rights. Our findings provide new insights in the capital structure adjustment process and have critical policy implications for the implementation of Basel III.
\end{abstract}

JEL Classification: G32, G21, G28

Keywords: dynamic capital structure, bank lending, pyramids, excess control rights, European banking

\footnotetext{
${ }^{\dagger}$ Corresponding author: amine.tarazi@unilim.fr (A. Tarazi), Tel: +33555149236.
} 


\section{Introduction}

Although banks are more leveraged than nonfinancial firms and are subject to regulatory minimum capital requirements, both theoretical (e.g., Orgler and Taggart, 1983; Myers and Rajan, 1998; Diamond and Rajan, 2000; Allen, Carletti, and Marquez, 2011) and empirical studies (e.g., Marcus, 1983; Flannery and Rangan, 2008) indicate that, like other firms, banks also have a target capital structure. The determinants of banks' capital structure are also found to be similar to those documented for nonfinancial firms (Gropp and Heider, 2011). Moreover, minimum capital requirements might not be binding since banks set the target capital ratio well above the regulatory minima (Ayuso, Pérez, and Saurina, 2004; Lindquist, 2004) and as a consequence such regulations might not affect banks' capital ratio adjustment as long as they are not violated (Berger, DeYoung, Flannery, Lee, and Öztekin, 2008). However, banks are also known to adjust to their target capital ratio faster than nonfinancial firms (Memmel and Raupach, 2010). Banks' assets are more liquid and banks can more easily adjust the size of their operations by expanding or shrinking their assets to reach the target capital structure.

In this paper, we question whether the way banks adjust to the target capital structure can be explained by internal governance mechanisms and specifically by excess control rights in pyramidal ownership structures. Excess control rights arise when the controlling shareholder has greater control rights than cash-flow rights. ${ }^{1}$ If, under certain conditions, controlling shareholders are more inclined to reap private benefits of control at the expense of minority shareholders, they will strongly value their controlling position. Such controlling shareholders might actually be reluctant to issue new equity that could dilute their private benefits of control. $^{2}$ Aversion to losing these benefits, to which we refer to as control dilution, will depend on the extent of such benefits. Extraction of private benefits is known to be easier in pyramids where controlling shareholders can enhance their control and achieve greater divergence between control and cash-flow rights. ${ }^{3}$ Such divergence provides the ability and the incentives to extract private benefits of control (e.g., Claessens, Djankov, Fan, and Lang,

\footnotetext{
${ }^{1}$ For more details on pyramidal ownership structure and specifically excess control rights see, e.g., La Porta, Lopez-de-Silanes, and Shleifer, 1999; Claessens, Djankov, and Lang, 2000; and Faccio and Lang, 2002.

${ }^{2}$ The controlling shareholder could bring the required equity himself but this would increase the costs of extracting private benefits (La Porta, Lopez-de-Silanes, Shleifer, and Vishny, 2002) by increasing the cash-flow rights and therefore the loss in terms of dividends.

${ }^{3}$ For more details on the expropriation hypothesis within pyramids (extraction of private benefits of control) see, e.g., Bertrand, Mehta, and Mullainathan, 2002; Claessens, Djankov, Fan, and Lang, 2002; Friedman, Johnson, and Mitton, 2003; Joh, 2003; Jiang, Kim, and Pang, 2011; Lin, Ma, and Xuan, 2011. For papers that specifically look at banks see, e.g., Boubakri and Ghouma, 2010; Azofra and Santamaría, 2011 and Lin, Ma, Malatesta, and Xuan, 2011.
} 
2002; Lin, Ma, Malatesta, and Xuan, 2011). We hence expect the fear of control dilution to be stronger in banks controlled by a shareholder with excess control rights, and as a consequence, such banks might not evenly weigh the way they choose to move towards the target capital ratio. Such banks might be reluctant to (externally) raise equity and would presumably first rely on internal resources when possible. Furthermore, they could move to the target ratio by adjusting their size and/or by reshuffling their assets more promptly than other banks. Specifically, the adjustment process might differently affect bank lending depending on the presence or absence of excess control rights.

To investigate the effect of control dilution, as captured by excess control rights, on banks' adjustment process towards the target, we use a novel and hand-crafted data set on the ultimate ownership structure of 341 commercial banks based in 17 Western European countries ${ }^{4}$ between 2002 and 2010. We use a partial adjustment model to estimate a bankspecific and time-varying target capital ratio and to identify the bank's initial position relatively to its target: above or below the target. More specifically, we investigate the various channels that banks rely on when they face a capital ratio shortfall (below the target) or surplus (above the target) to capture possible differences due to the presence of excess control rights. We look into how banks adjust their equity either externally (equity issues /repurchases) or internally (higher/lower earnings retention) and also into how they adjust their assets and particularly their lending. Indeed, in extreme cases banks could simply decrease their capital ratio by extending more loans (funded with new debt) or increase it by selling assets or reducing lending (leading to a lower amount of debt). But banks can also reallocate their assets to reach a different level of risk-weighted assets if they target a regulatory capital ratio such as the Tier1 capital ratio. ${ }^{5}$

We find that when control and cash-flow rights are equal, below-target banks adjust their Tier 1 regulatory capital ratio by issuing new equity and by lowering risk-weighted assets (by substituting safer assets to riskier ones) but not by reducing their assets and specifically their loans. When they face a surplus, such banks adjust both externally and internally (by repurchasing equity and lowering earnings retention) and expand their assets and specifically

\footnotetext{
${ }^{4}$ We focus on European countries where the presence of excess control rights is more acute compared to other countries, for instance, the U.S. (La Porta, Lopez-de-Silanes, Shleifer, and Vishny, 1998).

${ }^{5}$ While the literature on firms' capital structure considers the leverage ratio (debt/equity) or identically the capital ratio (equity/total assets), in the case of banks some broader measure of regulatory capital is generally used. Tier 1 capital is the narrowest definition of regulatory capital in force during our period of study. It is composed of ordinary shares and disclosed reserved (e.g., retained earnings, share premium reserves). It also includes other capital instruments (for example, preferred shares, hybrid capital securities) which will no more be eligible under the Basel III Accords (BIS, 2010a).
} 
their lending. However, when control rights exceed cash-flow rights, while they do repurchase equity when they face a surplus, banks are reluctant to issue any equity when they face a shortfall. In the latter case, banks not only draw on earnings to reach the target capital ratio but also shrink their assets in general and their lending in particular. This finding is consistent with our prediction that controlling shareholders with excess control rights fear dilution of control that may arise from equity issuance. As a consequence, external recapitalization is limited and banks rely on internal funds but also on downsizing.

We also take our investigation further and analyze whether the type of the largest ultimate controlling shareholder, the level of shareholder protection rights and the 2008 global financial crisis affect the impact of excess control rights on banks' capital ratio adjustment. Consistent with the view that family ownership (Claessens, Djankov, Fan, and Lang, 2002; Almeida and Wolfenzon, 2006; Villalonga and Amit, 2006) as well as weak shareholder protection rights (La Porta, Lopez-de-Silanes, Shleifer, and Vishny, 2002; Dyck and Zingales, 2004) increase the incentives of controlling shareholders to extract private benefits of control, we find that the impact of excess control rights is only effective for family-owned banks or banks operating in countries with relatively weak shareholder protection. Instead of issuing equity to move to the target capital ratio, such banks distribute less dividends and cut their assets including their loans. Moreover, we show that during the 2008 financial crisis banks controlled by a shareholder with excess control rights did issue -just like any other bankequity to adjust to the target instead of cutting their assets and specifically their lending. This is consistent with the view that ultimate controlling owners who expect to divert higher resources in the future might provide significant support to their firms during a crisis (Friedman, Johnson, and Mitton, 2003).

Our paper makes two main contributions to the capital structure adjustment and corporate governance literature. First, we build a bridge between the two strands of the literature by exploring the effect of control rights of the bank's ultimate owner in pyramids on capital structure adjustment. We investigate differences in the adjustment process towards the target capital ratio and particularly whether banks are reluctant to raise (external) equity and possibly limit their size and especially their lending in the presence of excess control rights of the bank's ultimate owner. Admati, DeMarzo, Hellwig, and Pfleiderer (2010) argue that banks would only limit their lending if issuing equity is more costly because of frictions and governance problems. Consistently, in our work, we show that banks do actually not refrain from lending except when control rights exceed cash-flow rights under very specific 
conditions. In the absence of excess control rights, banks do issue equity without slowing their lending to increase their capital ratio. By linking ownership structure to bank lending, our paper also contributes to the literature investigating the effect of foreign and domestic ownership on lending stability (e.g., Claessens and Van Horen (2013a, b) showing that foreign banks contributed to financial instability by strongly reducing their lending compared to domestic banks during the 2008 financial crisis). ${ }^{6} \mathrm{We}$ also add to the literature investigating asymmetries and/or cross-variations in the adjustment speed with which firms converge to the optimal capital structure (e.g., Byoun, 2008; Öztekin and Flannery, 2012; and more specifically Berger, DeYoung, Flannery, Lee, and Öztekin, 2008; Memmel and Raupach, 2010 for banks). Our study further contributes to the literature exploring the driving factors behind the reluctance of firms to recapitalize (e.g., Dittmar and Thakor (2007) who show that firms dislike raising equity if they expect disagreement on investment decisions with new investors). Second, unlike previous studies on pyramidal ownership structure (see, e.g., La Porta, Lopez-de-Silanes, and Shleifer, 1999; Claessens, Djankov, and Lang, 2000 and Faccio and Lang, 2002 for nonfinancial firms, and Caprio, Laeven, and Levine, 2007 and Laeven and Levine, 2009 for banks) which typically focus on the largest publicly traded corporations at a given point in time, we gather a broader and more detailed database on ultimate ownership structure including large and small institutions, both publicly traded and privately owned for three different years of the sample period (2004, 2006 and 2010) to check for possible changes in the ultimate ownership structure, especially after the 2008 financial crisis.

Our study also contributes to the debate on the post-crisis bank regulatory framework and more specifically on the new standards for capital regulation. The Basel Committee on Banking Supervision (BIS, 2010a) has implemented new rules not only to strengthen the existing capital requirements but also to improve the quality of regulatory capital by excluding preferred shares, which in general do not carry control rights, from the new and narrower definition called Core Tier 1 capital. Such requirements might entail high costs for controlling shareholders with excess control rights which, according to our findings, could encourage banks not to issue common equity to adjust closer to their target capital ratio. Rather, our results show that such controlled banks will adjust by reducing their size and

\footnotetext{
${ }^{6}$ Other studies investigate whether the implementation of the risk-based capital requirements had an impact on bank lending and show that the severity of the 1990-1992 credit crunch in the U.S. can be explained by the introduction of more stringent capital rules (e.g., Berger and Udell, 1994; Peek and Rosengren, 1995; Brinkmann and Horvitz, 1995).
} 
notably their lending activities, and potentially their overall contribution to the real economy. Our work also addresses the concerns of the Basel Committee on Banking Supervision (BIS, 2010b) highlighting the relevance of sound corporate governance in the banking industry and recommending the disclosure of banking entities' ownership.

The remainder of the paper proceeds as follows. Section 2 describes the data, defines the ultimate ownership variables and provides some statistics. In Section 3, we specify the model we use to conduct our empirical investigation. Section 4 provides estimation results and Section 5 shows robustness checks. Section 6 concludes the paper and provides some policy implications.

\section{Data and ultimate ownership variables}

We start by describing our sample and then present the procedure we follow to measure excess control rights as well as the characteristics of the computed ownership variables.

\subsection{Sample}

Our study spans the 2002-2010 period and focuses on commercial banks established in 17 European countries: Austria, Belgium, Denmark, Finland, France, Germany, Greece, Ireland, Italy, Luxembourg, the Netherlands, Norway, Portugal, Spain, Sweden, Switzerland and, the United Kingdom. Bank-level accounting data used in this study are retrieved from BvD Bankscope. To collect our ownership data, we use both Bankscope and Amadeus as primary sources. We collect our macroeconomic data from World Development Indicators (The World Bank) and Bloomberg and we use Thomson Reuters Advanced Analytics to identify mergers and acquisitions involving European commercial banks. For each bank, we use unconsolidated data if available; otherwise we use consolidated statements. ${ }^{7}$ For the time period and countries covered by our study, we identify 467 banks for which Bankscope reports information on our variables of interest, especially the risk-based Tier 1 capital ratio. We restrict our sample to institutions actually involved in lending by requiring the bank to have a loans to total assets ratio above $10 \%{ }^{8}$ After eliminating extreme bank year

\footnotetext{
${ }^{7}$ Note that our empirical analysis relies to a large extent on unconsolidated bank statements. In some cases, Bankscope provides information for the Tier 1 capital ratio only for consolidated data. We check the robustness of our results using unconsolidated data solely.

${ }^{8}$ Bankscope defines as commercial banks institutions that are mainly active in a combination of retail banking, wholesale banking and private banking. This broad definition implies that some banks considered as commercial banks exhibit a very low loans to total assets ratio. Since our aim is to analyze banks' lending behavior, we need to further restrict our sample.
} 
observations for the main variables (1\% lowest and highest values) and 28 banks for which we are not able to identify the ultimate controlling owners, we are left with a final sample of 2,204 annual observations corresponding to 341 commercial banks, 111 of which are listed (see Table A1 in Appendix A for a breakdown of these banks by country and Table A2 for general descriptive statistics). To gauge the representativeness of our sample, we compare the aggregate total assets of our sample banks in a given country to the aggregate total assets of all the banks covered by Bankscope in the same country over the 2002-2010 period (see Table A1 in Appendix A). On average, our final sample covers more than $78 \%$ of banks' total assets in the considered countries.

\subsection{Building of control chains and ultimate ownership variables}

To measure the ultimate owner's excess control rights, we first need to build the control chains to identify the ultimate controlling owners for each bank. Although prior studies (La Porta, Lopez-de-Silanes, and Shleifer, 1999; Caprio, Laeven, and Levine, 2007; Laeven and Levine, 2008, 2009) argue that ownership structure is stable over time, we construct the control chain for each bank for the years 2004, 2006 and 2010. ${ }^{9}$ Data from 2004 and 2006 are used to reflect ownership prior to the 2008 global financial crisis. To capture possible changes stemming from government intervention during the crisis we also use ownership information from $2010 .^{10}$

To build the control chains, we need to define a threshold (minimum percentage of shares held) to identify each owner along the chain. Following previous studies on both banks (Caprio, Laeven, and Levine, 2007; Laeven and Levine, 2009) and nonfinancial firms (La Porta, Lopez-de-Silanes, and Shleifer, 1999; Laeven and Levine, 2008), we use a control threshold of $10 \%$ assuming that it provides a significant fraction of votes for effective control. We first identify the major shareholders (those holding at least $10 \%$ of the shares) of each bank by gathering data on direct ownership from Bankscope using DVDs issued in 2004, 2006 and 2010 and complete it with information from annual reports disclosed in the banks' web sites. We classify a bank as controlled if it has at least one shareholder with $10 \%$ or more of total outstanding shares. Otherwise, we consider the bank to be widely held. If some of the identified major shareholders are independent (such as a family or a state), that is, if they are

\footnotetext{
${ }^{9}$ Bankscope and Amadeus do not provide detailed information on ownership structure, namely on the type of the shareholder (firm, bank, institutional investors and so on) before 2004.

${ }^{10}$ Bankscope and Amadeus update ownership data every 18 months and historical data are not disclosed; information is only provided for the last changes with the corresponding dates.
} 
not controlled by another shareholder, we consider them to be the ultimate controlling owners. If, however, some or all of the major shareholders identified at this first level of the control chain are themselves financial or nonfinancial corporations, we go deeper and build indirect control chains by identifying their owners, the owners of their owners until we reach ultimate shareholders. ${ }^{11}$ Since Bankscope provides ownership information only for banks, we use the Amadeus database together with annual reports (still considering data from 2004, 2006 and 2010) to collect ownership data on nonfinancial firms that are major shareholders at the intermediate levels of indirect control chains.

The control chains that we build are used to compute voting and cash-flow rights (and excess control rights) by following the method initially proposed by La Porta, Lopez-deSilanes, and Shleifer (1999). An ultimate controlling owner can hold a bank through a direct and/or an indirect control chain. The aggregate voting rights of an ultimate controlling owner (ControlRights) are the sum of direct and indirect voting rights held in the bank. Direct voting rights involve shares registered in the ultimate controlling shareholder's name whereas indirect voting rights refer to the shares held by entities that the ultimate shareholder controls at least at the $10 \%$ level. When a bank is controlled by multiple ultimate owners, ${ }^{12}$ we define the ultimate controlling shareholder as the owner with the greatest voting rights. The aggregate cash-flow rights (Cash-flowRights) of an ultimate controlling shareholder are the sum of direct and indirect cash-flow rights held in the bank. While direct cash-flow rights refer to the percentage of shares directly held in the bank, indirect cash-flow rights are calculated as the product of the percentages of shares held by the shareholders along the indirect control chain linking the ultimate controlling owner to the bank. If the bank is widely held (there is no controlling owner) or if the control chain is a cross-holding ${ }^{13}$ we set voting rights and cash-flow rights equal to zero.

Substantial divergence between voting and cash-flow rights may exist in the presence of

\footnotetext{
${ }^{11}$ Given a control threshold of $10 \%$, the maximum number of controlling shareholders at each level of the bank's control chain is equal to ten. If $\mathrm{n}$ stands for the number of levels in the control chain, the maximum number of ultimate controlling owners for a control threshold of $10 \%$ is $10^{\mathrm{n}}$. In our sample, the maximum number of intermediate levels necessary to trace the indirect control chain until the ultimate owner is eight. The number of different ultimate controlling owners for a given bank in our sample also reaches a maximum of eight.

${ }^{12}$ Over the 2002-2010 period, among the set of controlled banks in our sample, 223 are continuously classified as controlled by a single ultimate owner and 60 are continuously classified as controlled by multiple ultimate owners while 32 banks switch from one category to the other.

${ }^{13}$ A bank's control chain is a cross-holding at the $10 \%$ threshold if a corporation holds a stake of at least $10 \%$ in the bank which in turn holds a stake of at least $10 \%$ in that corporation.
} 
indirect control chains. ${ }^{14}$ We define excess control rights as the difference between voting and cash-flow rights (ExcessControl=ControlRights-Cash-flowRights) as in La Porta, Lopez-deSilanes, and Shleifer (1999). We then classify the sampled banks into two groups: banks without excess control rights (ExcessControl=0) and banks with excess control rights (ExcessControl $>0) .{ }^{15} \mathrm{~A}$ bank is classified as without excess control rights if (i) it is controlled by an ultimate owner with equal voting and cash-flow rights, (ii) it is widely held or (iii) if its control chain is a cross-holding. A bank is classified as with excess control rights if it is controlled by an ultimate owner with greater voting than cash-flow rights. ${ }^{16}$

Fig. 1 provides a simple example of a control chain to illustrate how we identify the ultimate controlling owners of each bank and how we compute voting and cash-flow rights based on the method proposed by La Porta, Lopez-de-Silanes, and Shleifer (1999). Three entities C6, C4 and C5 are identified as the ultimate controlling owners of the bank reported in Fig. 1. The largest ultimate controlling owner (with the greatest voting rights) is C6. This ultimate controlling owner holds the bank directly and indirectly through two other intermediate corporations $\mathrm{C} 1$ and $\mathrm{C} 3$. Direct voting rights of C6 are identical to his direct cash-flow rights and equal to $40 \%$. Indirect voting rights of this ultimate controlling owner are equal to $30 \%$ (the percentage of shares held by $\mathrm{C} 1$ ) whereas indirect cash-flow rights are equal to $0.6 \%$ $(10 \% \times 20 \% \times 30 \%)$. The aggregate voting rights of C6 are hence equal to $70 \%(30+40)$ whereas the aggregate cash-flow rights are $40.6 \%(0.6+40)$. The difference between both aggregate rights (excess control rights) of C6 is equal to $29.4 \%$ (70 - 40.6).

[Insert Fig. 1 about here]

\subsection{Ultimate ownership characteristics and financial profiles of the sample banks}

Our data set indicates that $83 \%$ of the observations refer to banks controlled by at least one

\footnotetext{
${ }^{14}$ The divergence between voting and cash-flow rights may arise from both indirect control chains (pyramids and multiple holdings) and dual class shares. Bankscope and Amadeus measure ownership using the voting rights and do not provide information on cash-flow rights. Given the information we have and in line with previous literature (Caprio, Laeven, and Levine, 2007; Laeven and Levine 2009), we consider the divergence between voting and cash-flow rights stemming from indirect control chains. We do not view this as a serious shortcoming for our study as previous studies (Claessens, Djankov, Fan, and Lang, 2002; Faccio and Lang, 2002; Azofra and Santamaría, 2011) show that the use of dual class shares is relatively scarce.

${ }^{15}$ Ownership structure and particularly the divergence between voting and cash-flow rights can to some extent change over time; accordingly, the classification of banks as without or with excess control rights might also change. Amongst the 341 banks in our sample, 195 are continuously categorized as without excess control rights and 113 as with excess control rights while 33 banks switch from one category to the other over the sample period.

${ }^{16}$ In our sample, the difference between both rights (ExcessControl) is generally relatively high. It is lower than $10 \%$ only in the case of five banks and we classify them as banks with excess control rights.
} 
ultimate shareholder. Amongst banks that are controlled, 57\% of the observations relate to an ultimate shareholder with equal control and cash-flow rights and $43 \%$ to an ultimate shareholder with excess control rights. This sample composition allows us to accurately conduct our empirical investigation.

We report in Table 1 summary statistics on the computed ultimate ownership variables (ControlRights, Cash-flowRights and ExcessControl) for both the subsamples of banks without and with excess control rights. For banks without excess control rights, voting and cash-flow rights both amount to about $51 \%$, on average. Amongst these banks, those that are controlled by an ultimate owner exhibit, on average, a higher percentage. ${ }^{17}$ In such a case, an ultimate controlling shareholder is more inclined towards profit maximization (Azofra and Santamaría, 2011). For banks with excess control rights, the largest ultimate controlling shareholder holds on average more than $80 \%$ of the voting rights and only around $36 \%$ of the cash-flow rights. This leads to an average divergence between voting rights and cash-flow rights of almost $44 \%$. As cash-flow rights are more than two times lower than voting rights, the ultimate controlling shareholder would be more inclined to extract private benefits and, in turn, to protect his voting rights rather than his cash-flow rights.

Table 2 reports information on the type of the largest ultimate controlling owner. It shows differences for banks without or with excess control rights. For banks without excess control rights, the largest ultimate controlling owner is predominantly (almost $42 \%$ of the observations) another bank (Bank). This proportion is more than two times lower for banks with excess control rights (more than $17 \%$ of the observations). This is consistent with the view that banks, when they are controlling shareholders, are less likely to engage in expropriation as the resulting benefits are distributed among multiple owners and also because regulation, when stringently enforced, makes expropriation more costly (Villalonga and Amit, 2006; Haw, Ho, Hu, and $\mathrm{Wu}, 2010$ ). Not surprisingly, individuals/families ${ }^{18}$ (Family) and states $^{19}$ (State) are the predominant largest ultimate controlling shareholders of banks with

\footnotetext{
${ }^{17}$ This percentage amounts to 69 which is not reported in Table 1.

${ }^{18}$ We follow La Porta, Lopez-de-Silanes, and Shleifer (1999) by classifying a bank as family controlled if the controlling shareholder is a person. We therefore include banks that are controlled by a manager inside this category. Note that in our sample only six banks are controlled by managers, four of which are banks with excess control rights.

${ }^{19}$ The proportion of state ownership in the full sample $(10.03 \%)$ is higher than in previous studies (Faccio and Lang, 2002; Caprio, Laeven, and Levine, 2007). This is because we consider not only large and publicly traded banks but also small and privately owned banks and because of the outcome of the 2008 financial crisis with massive government intervention either by capital injections and/or by nationalizations. Before the crisis (20022006), state ownership represents $4.72 \%$ of the observations in the sample of 341 banks, which is almost similar to what is reported in previous studies (Faccio and Lang, 2002; Caprio, Laeven, and Levine, 2007).
} 
excess control rights (around $30 \%$ and $22 \%$ of the observations respectively). However, they are less present in banks without excess control rights (about 15\% and 3\% of the observations respectively). The divergence between both rights could enable ultimate controlling owners, and especially families, to expropriate minority shareholders and divert a larger fraction of resources (Claessens, Djankov, Fan, and Lang, 2002; Almeida and Wolfenzon, 2006). Institutional investors (Institutional) and industrial companies (Industry) are also more frequently present as ultimate controlling shareholders in banks with excess control rights (around $16 \%$ and $9 \%$ of the observations respectively) than in banks without excess control rights (nearly $8 \%$ and $2 \%$ of the observations respectively). Foundations (Foundation) are quite evenly distributed between the two subsamples of banks without and with excess control rights, with a much weaker presence as shareholders in both cases. Table 2 also reports the extent of widely held banks and cross-holdings in the subsample of banks without excess control rights. They respectively represent about $24 \%$ and $2 \%$ of the observations.

Table 3 compares the summary statistics on key financial variables for the subsamples of banks without and with excess control rights. Banks with excess control rights rely more on traditional intermediation activities (higher loans to total assets ratio). In line with the expropriation hypothesis of pyramidal ownership structure (Claessens, Djankov, Fan, and Lang, 2002; Azofra and Santamaría, 2011), they have poorer loan quality (higher proportion of non-performing loans) and are less profitable (lower return on assets and return on equity). The table also shows that banks with excess control rights hold lower Tier 1 capital ratios (either risk-based or not), possibly because of the fear of control dilution. Furthermore, banks with excess control rights are less likely to pay dividends, presumably to more easily increase their capital ratios via internal funds or because of the effect of expropriation (Faccio, Lang, and Young, 2001).

[Insert Tables 1, 2 and 3 about here]

We now move to the approach we follow to investigate the impact of excess control rights on the bank's adjustment process towards the target capital ratio.

\section{Methodology}

In this paper, we question whether the way banks adjust their capital ratio towards the target level is affected by the ultimate owner's excess control rights. Banks have two options that can be combined to reach their target capital ratio: they can adjust the numerator (equity issues/repurchases and/or earnings retention) and/or the denominator (assets adjustment 
and/or risk-weighted assets) of their capital ratio. Depending on their control/ownership pattern, banks might not uniformly weigh these different adjustment options. Specifically, banks controlled by a shareholder with excess control rights might be reluctant to issue equity since external recapitalization can lead to control dilution. Instead, such banks are likely to increase retained earnings and/or decrease their size (loans or other assets) or risk-weighted assets (asset substitution) when they need to increase their capital ratio.

Our approach involves two steps. We first consider a partial adjustment model to estimate a bank-specific and time-varying target capital ratio and the gap between the target and the lagged actual capital ratios. We then investigate how banks increase or decrease their capital ratio to adjust to the target by modifying their regulatory capital (numerator) and/or assets (denominator) depending on their controlling owners' excess control rights.

\subsection{Estimating the target capital ratio and computing deviations from the target}

We model the target capital ratio as a function of the bank's and country's characteristics (e.g., Marcus, 1983; Gropp and Heider, 2011) as follows:

$$
\mathrm{k}_{\mathrm{i}, \mathrm{t}}^{*}=\varphi^{\prime} \mathrm{X}_{\mathrm{i}, \mathrm{t}-1}+\rho \text { GDPGrowth } \mathrm{c}, \mathrm{t}-1+\omega^{\prime} \text { Country }+\tau^{\prime} \text { Year }+\mu_{\mathrm{i}},
$$

where $\mathrm{k}^{*}$ is the target level of the bank's Tier 1 capital ratio defined as Tier 1 regulatory capital divided by either total assets (Tier1TA) or risk-weighted assets (Tier1RWA) ${ }^{20} \mathrm{X}$ is a vector of observable variables: the dummy variable ExcessCR ${ }^{21}$ that captures the presence of excess control rights, ${ }^{22}$ bank size (Log(Assets)), the return on assets (ROA), the ratio of loan

\footnotetext{
${ }^{20}$ In this study, we focus exclusively on the Tier 1 capital ratio (risk-based or nonrisk-based) and ignore the total capital ratio. Tier 1 capital is mainly composed of ordinary shares. Tier 2 capital does not involve voting rights and therefore the fear of control dilution might not be observed in changes in the total regulatory capital (Tier 1 + Tier 2).

${ }^{21}$ To capture excess control rights, we define a dummy variable ExcessCR which is equal to one if the voting rights are greater than the cash-flow rights, and zero otherwise. We use a binary variable which we consider to be more accurate than a continuous variable in our specific setting: (i) a binary variable is more likely to be independent of the method used to compute indirect control rights, the last link principle (e.g., La Porta, Lopezde-Silanes, and Shleifer, 1999; Azofra and Santamaría, 2011) or the weakest link principle method (e.g., Claessens, Djankov, and Lang, 2000; Lin, Ma, Malatesta, and Xuan, 2011); phrased differently, qualitatively, the two available methods would give the same classification (a bank with or without excess control rights) but quantitatively the computed excess control rights can be very different with the two methods; (ii) we have not collected ownership data on a continuous basis (every year), a binary variable is more likely to remain stable over time; (iii) we do not account for excess control rights that may arise from the existence of dual class shares; (vi) in our sample, the difference between both rights is generally relatively high; it is lower than $10 \%$ only in the case of five banks.

${ }^{22}$ We include the dummy variable ExcessCR because, on average, banks without excess control rights exhibit higher Tier 1 capital ratios than banks with excess control rights (see Table 3). Our specification is hence flexible enough to account for possible differences in the target capital ratio for banks with or without excess control rights.
} 
loss provisions (LoanlossProv), the ratio of net loans to total assets (Loans), the ratio of long term market funding to total funding as a proxy of market discipline (MarketDiscipline) and a dummy variable for listed banks (Listed); GDPGrowth is the annual growth rate of real GDP for country c (see Table A3 in Appendix A for a description of these variables and summary statistics). ${ }^{23}$ Time-varying explanatory variables are lagged by one year to avoid simultaneity. Country and Year are respectively vectors of country and year dummies. $\mu_{i}$ is a vector of bank fixed effects.

The model specified in Eq. (1) assumes that banks will always maintain their capital ratio at its target level. This is only possible in a frictionless world. In practice, banks need time to adjust their capital and their assets to modify their capital ratio and move to the target level. Hence, to account for adjustment costs, we consider a partial adjustment framework (Eq. (2)) where banks adjust a constant portion $\lambda(\lambda$ is a scalar adjustment speed, $\lambda \in[0 ; 1]$ with higher values of $\lambda$ indicating faster adjustment) of the gap between the target and the lagged actual capital ratios:

$$
\mathrm{k}_{\mathrm{i}, \mathrm{t}}-\mathrm{k}_{\mathrm{i}, \mathrm{t}-1}=\lambda\left(\mathrm{k}_{\mathrm{i}, \mathrm{t}}^{*}-\mathrm{k}_{\mathrm{i}, \mathrm{t}-1}\right)+\eta_{\mathrm{i}, \mathrm{t}}
$$

Substituting Eq. (1) into Eq. (2) and rearranging gives the following estimation model:

$$
\mathrm{k}_{\mathrm{i}, \mathrm{t}}=(1-\lambda) \mathrm{k}_{\mathrm{i}, \mathrm{t}-1}+\lambda\left(\varphi^{\prime} \mathrm{X}_{\mathrm{i}, \mathrm{t}-1}+\rho \text { GDPGrowth }_{\mathrm{c}, \mathrm{t}-1}+\omega^{\prime} \text { Country }^{\prime} \tau^{\prime} \text { Year }+\mu_{\mathrm{i}}\right)+\eta_{\mathrm{i}, \mathrm{t}}
$$

We use the average adjustment speed $(\hat{\lambda})$ and the vector of coefficients ${ }^{24}$ obtained from estimating Eq. (3) to compute a fitted value of the target Tier 1 capital ratio ${ }^{25}$ for each bank every year $\left(\hat{\mathrm{k}}_{\mathrm{i}, \mathrm{t}}^{*}\right)$. This bank-specific and time-varying estimated target capital ratio is then used to compute the gap $\left(\mathrm{Gap}_{\mathrm{it}-1}\right)$ between the estimated target capital ratio $\left(\hat{\mathrm{k}}_{\mathrm{i}, \mathrm{t}}^{*}\right)$ and the lagged actual capital ratio $\left(\mathrm{k}_{\mathrm{i}, \mathrm{t}-1}\right)$ as follows:

$$
\operatorname{Gap}_{\mathrm{i}, \mathrm{t}-1}=\hat{\mathrm{k}}_{\mathrm{i}, \mathrm{t}}^{*}-\mathrm{k}_{\mathrm{i}, \mathrm{t}-1}
$$

\footnotetext{
${ }^{23}$ On the whole, the correlations among the explanatory variables used to estimate the target capital ratio are low.

${ }^{24}$ We estimate Eq. (3) using the Blundell and Bond (1998) Generalized Method of Moments (GMM). The results are reported in Table A4 in Appendix A. As shown in Table A4, the coefficients estimates are generally significant and their signs are, on the whole, consistent with previous studies (see Table A3 in Appendix A for the expected signs).

${ }^{25}$ Note that the coefficients obtained from estimating Eq. (3) are the product of the adjustment speed $(\lambda)$ and the variable's contribution to the bank's target capital ratio. Hence, to get the parameter value of the contribution of each variable we divide the estimated regression coefficient for that variable by the adjustment speed $\lambda$. The estimated values of the target capital ratio are computed from Eq. (1) as follows:

$\hat{\mathrm{k}}_{\mathrm{i}, \mathrm{t}}^{*}=\widehat{\varphi}^{\prime} \mathrm{X}_{\mathrm{i}, \mathrm{t}-1}+\hat{\rho} \mathrm{GDPGrowth} \mathrm{c,t-1}+\widehat{\omega^{\prime}}$ Country $+\widehat{\tau}^{\prime}$ Year $+\widehat{\mu}_{\mathrm{i}}$
} 
Our objective is to test whether banks controlled by a shareholder with excess control rights are reluctant to raise equity and therefore downsize by possibly refraining from lending. We hence separate the cases where banks are above the target (kSurplus) and below the target (kDeficit) and for easier interpretation of the results we consider the absolute value of the gap $\left(\mathrm{Gap}_{\mathrm{it}-1}\right)$ :

$$
\begin{aligned}
& \text { kSurplus }_{\mathrm{i}, \mathrm{t}-1}=\left|\operatorname{Gap}_{\mathrm{i}, \mathrm{t}-1}\right| \text { if } \mathrm{k}_{\mathrm{i}, \mathrm{t}-1}>\hat{\mathrm{k}}_{\mathrm{i}, \mathrm{t}}^{*} \text {, and zero otherwise } \\
& \text { kDeficit }_{\mathrm{i}, \mathrm{t}-1}=\left|\mathrm{Gap}_{\mathrm{i}, \mathrm{t}-1}\right| \text { if } \mathrm{k}_{\mathrm{i}, \mathrm{t}-1}<\hat{\mathrm{k}}_{\mathrm{i}, \mathrm{t}}^{*} \text {, and zero otherwise }
\end{aligned}
$$

When the lagged actual capital ratio is above the target level, the bank faces a capital ratio surplus (kSurplus). In this case, the bank can adjust towards the target capital ratio by (i) decreasing its capital (equity repurchase and/or lower earnings retention) or (ii) expanding its assets (by lending more and/or investing in other assets) or its risk-weighted assets. When the lagged actual capital ratio is below the target level, the bank faces a shortfall (kDeficit). In such a case, to move to the target level, it needs to (i) increase its capital (by issuing new equity and/or limiting dividend distribution) or (ii) reduce its assets (by shrinking lending and/or other assets) or its risk-weighted assets.

\subsection{Excess control rights and adjustments towards the target capital ratio}

Our aim is to investigate how banks respond to a capital ratio deficit or surplus when they are controlled by a shareholder with equal control and cash-flow rights or by a shareholder with excess control rights.

Banks can change their capital (thereafter referred to as capital adjustment) either externally by issuing/repurchasing equity or internally by distributing lower or larger amounts of earnings. ${ }^{26}$ Differentiating between external and internal changes in capital is important to test whether banks controlled by a shareholder with excess control rights are reluctant to issue equity when they are below their target capital ratio. As a proxy for the level of capital, we use the Tier 1 regulatory capital. We hence define external change in capital (denoted thereafter $\Delta$ Tier1) as the annual change in the level of Tier 1 capital minus the amount of retained earnings, all scaled by average assets defined as: (total assets at time $\mathrm{t}+$ total assets at time t-1)/2. Internal change in capital (thereafter RetainedEarnings) is measured by the amount of retained earnings scaled by average assets. Banks can also adjust their assets to

\footnotetext{
${ }^{26}$ Annual change in capital can be expressed as the annual change in external capital plus the current amount of retained earnings, where retained earnings are defined as the current net income minus the current dividend payment.
} 
move closer to the target capital ratio. We capture such adjustments (thereafter referred to as assets adjustment) using the annual change (scaled by average assets) in the following outcomes: total assets, net loans (excluding interbank loans) and risk-weighted assets, denoted thereafter $\Delta$ Assets, $\Delta$ Loans and $\Delta \mathrm{RWA}$ respectively. We hence specify the following dynamic model:

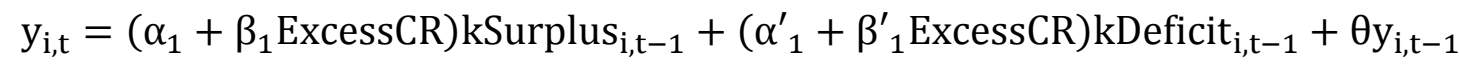

$$
\begin{aligned}
& +\delta^{\prime} \mathrm{Z}_{\mathrm{i}, \mathrm{t}-1}+\gamma^{\prime} \mathrm{V}_{\mathrm{c}, \mathrm{t}-1}+\alpha_{0}+\omega^{\prime} \text { Country }+\tau^{\prime} \text { Year }+\varepsilon_{\mathrm{i}, \mathrm{t}},
\end{aligned}
$$

where $\mathrm{y}$ is the dependent variable which accounts either for capital adjustment $(\Delta$ Tier1, RetainedEarnings) or assets adjustment ( $\Delta$ Assets, $\Delta$ Loans or $\Delta$ RWA); kSurplus and kDeficit refer to the absolute value of the gap between the target and the lagged actual ratios when the bank is above or below the target level respectively; ExcessCR is a dummy variable capturing the presence of excess control rights; $\mathrm{Z}$ and $\mathrm{V}$ are respectively vectors of bank- and countrylevel control variables. ${ }^{27}$ Time-varying bank- and country-level control variables are lagged (one year) to deal with possible endogeneity issues. Bank-level control variables are: the dummy variable ExcessCR; the deposits to assets ratio as a measure of funding structure (Deposits); the natural logarithm of bank age as a proxy of growth opportunities ( $\log ($ Age)); a rescue dummy (Rescue) to control for banks which were rescued during the 2008 crisis; an index for cross listed banks (CrossListed) which might more easily raise equity than banks listed on a single stock exchange or privately owned banks; and finally a merger acquisition dummy (Merger) to account for banks which experienced a merger-acquisition event during the period we study. Control variables computed at the country-level (V) include the 3-month interbank rate (3MInterbankRate) and the growth rate of real GDP (GDPGrowth) to account for macroeconomic conditions as well as an indicator of the size and depth of a country's stock market (StockTraded) defined as the stock market capitalization (value of listed shares) to GDP ratio. Similarly to Eq. (1) and Eq. (3), Country and Year respectively denote vectors of country and year dummies.

The parameters $\alpha_{1}$ and $\alpha_{1}^{\prime}$ refer to banks without excess control rights (ExcessCR=0). They measure the extent to which capital and assets are modified by such banks to adjust to the target capital ratio downwards (kSurplus) and upwards (kDeficit) respectively. As argued above, banks without excess control rights might indifferently adjust their capital ratio upwards and downwards because their ultimate controlling owners do not fear control

\footnotetext{
${ }^{27}$ See Table A5 in Appendix A for the definition and the descriptive statistics for the variables used to estimate Eq. (6). The correlations among the main explanatory variables ( $\mathrm{Z}$ and $\mathrm{V})$ are generally very low.
} 
dilution. When they are below their target, we expect these banks to increase their capital internally and externally without strongly reducing their loans and other assets: $\alpha^{\prime}{ }_{1}$ positive and significant for capital adjustment variables and $\alpha_{1}^{\prime}$ non-significant or significant and negative for assets adjustment variables. When they are above the target, they are expected to decrease their capital internally and externally to temper asset expansion $\left(\alpha_{1}\right.$ negative and significant for capital adjustment variables and non-significant for assets adjustment variables) and/or increase their assets ( $\alpha_{1}$ significant and positive for assets adjustment variables).

The parameters $\alpha_{1}+\beta_{1}$ and $\alpha^{\prime}{ }_{1}+\beta^{\prime}{ }_{1}$ refer to banks with excess control rights (ExcessCR=1) and respectively correspond to the proportion of capital and assets used to adjust the capital ratio downwards (kSurplus) and upwards (kDeficit). When they are below their target, banks with excess control rights are expected to be reluctant to issue equity ( $\beta^{\prime}{ }_{1}$ significant and negative for $\Delta$ Tier1). In the extreme case, such banks might not be issuing equity at all (if the sum $\alpha_{1}^{\prime}+\beta_{1}^{\prime}$ is not significantly different from zero). Such banks might increase their retained earnings and/or shrink their assets (loans or other assets). We hence expect the sum $\alpha^{\prime}{ }_{1}+\beta_{1}^{\prime}$ to be significantly positive with regards to earnings retention (RetainedEarnings) and significantly negative for assets adjustment variables ( $\Delta$ Assets, $\triangle$ Loans and $\triangle \mathrm{RWA}$ ), indicating that such banks counterbalance their reluctance to raise equity by increasing retained earnings and/or deleveraging. When they are above their target, because control dilution is not an issue, such banks are expected to behave similarly to banks without excess control rights $\left(\alpha_{1}+\beta_{1}\right.$ significant for $\Delta$ Tier1 and significant or non-significant for RetainedEarnings, $\Delta$ Assets, $\Delta$ Loans and $\Delta$ RWA).

\section{Results}

We first investigate the link between excess control rights and the bank's capital ratio adjustment and then look at various factors that could influence such a relationship.

\subsection{Effect of excess control rights on adjustments towards the target capital ratio}

In this study, we aim to test for differences in banks' responses to deviations from their target capital ratio depending on the presence or absence of excess control rights.

We estimate the coefficients of the dynamic panel model presented in Eq. (6) using the Blundell and Bond (1998) Generalized Method of Moments (GMM). We check the validity of 
the GMM instruments (lagged values) using the Hansen test (a test of exogeneity of all instruments as a group) and the Arellano and Bond test for the absence of second order residual autocorrelation (AR2 test). Table 4 reports the results with the two different definitions of the Tier 1 capital ratio we use (Tier1TA and Tier1RWA) and all the dependent variables used to capture capital adjustment ( $\Delta$ Tier1 and RetainedEarnings) and assets adjustment ( $\Delta$ Assets, $\Delta$ Loans and $\Delta$ RWA).

Based on the results in Table $4,{ }^{28}$ banks controlled by a shareholder with equal control and cash-flow rights respond to a capital ratio surplus (kSurplus) by both reducing capital and expanding assets. The decrease in capital is achieved both externally (equity repurchase) and internally (reduction in earnings retention): $\alpha_{1}$ is negative and significant for $\Delta$ Tier1 and RetainedEarnings. Such banks expand their assets, in particular their lending, and increase their risk-weighted assets by substituting riskier assets to safer ones ( $\alpha_{1}$ positive and significant for $\Delta$ Assets, $\Delta$ Loans and $\Delta$ RWA). When they face a capital ratio shortfall (kDeficit), such banks converge to the target by issuing new equity ( $\alpha^{\prime}{ }_{1}$ positive and significant for $\Delta$ Tier1). Such banks do not increase their capital internally but most importantly they do not decrease their assets and particularly their lending $\left(\alpha^{\prime}{ }_{1}\right.$ nonsignificant for RetainedEarnings, $\Delta$ Assets and $\Delta$ Loans) although they do to some extent reshuffle their assets as shown by the results with the risk-based Tier 1 ratio (Tier1RWA). On the whole, these results suggest that the ultimate controlling owners of such banks do not fear control dilution and increase their capital ratio by issuing equity without reducing their assets and particularly their lending.

When they are above their target capital ratio, banks controlled by a shareholder with excess control rights are found to decrease their capital through equity repurchases $\left(\alpha_{1}+\beta_{1}\right.$ significant for $\Delta$ Tier1) but they do not expand their assets by increasing their lending and do not reshuffle their assets $\left(\alpha_{1}+\beta_{1}\right.$ non-significant for $\Delta$ Assets, $\Delta$ Loans and $\Delta$ RWA). When such banks are below their target, conversely to banks with equal control and cash-flow rights, they do not issue equity $\left(\beta^{\prime}{ }_{1}\right.$ significant and $\alpha^{\prime}{ }_{1}+\beta_{1}^{\prime}$ non-significant for $\Delta$ Tier1) which is consistent with our conjecture that ultimate owners with excess control rights fear control dilution. Alternatively, these banks adopt other adjustment methods to preserve the

\footnotetext{
${ }^{28}$ Note that in all the regressions, we report the results obtained when the dummy variable ExcessCR is included among the explanatory variables in Eq. (3) to estimate the target ratio for each bank (see Table A4 in Appendix A). We obtain almost similar results (not reported here but available on request) when we compute kSurplus and kDeficit on the basis of a target estimated without the dummy variable ExcessCR (columns referred to as Baseline in Table A4 of Appendix A).
} 
control power of the ultimate owners: they counterbalance their reluctance to issue new equity by increasing their capital internally $\left(\alpha^{\prime}{ }_{1}+\beta^{\prime}{ }_{1}\right.$ positive and significant for RetainedEarnings) but also by shrinking/reshuffling their assets and particularly their loans $\left(\alpha^{\prime}{ }_{1}+\beta_{1}^{\prime}\right.$ negative and significant for $\Delta$ Assets, $\Delta$ Loans and $\Delta$ RWA).

Our results are not only statistically significant but also economically meaningful. A one standard deviation (2.61) increase in the capital ratio shortfall leads to a decrease in $\Delta$ Loans by $28 \%$ of its mean (corresponding to a strong deceleration in loan growth) for banks with excess control rights but does not affect loan growth for banks without excess control rights. A one standard deviation (2.35) increase in the capital ratio surplus is associated with a $19 \%$ increase in $\Delta$ Loans, a $23 \%$ decrease in $\Delta$ Tier1 and a $21 \%$ decrease in RetainedEarnings (of their means) for banks without excess control rights. For banks with excess control rights such a change in the capital ratio surplus is only associated with a decrease in $\Delta$ Tier1 by $29 \%$ of its mean.

\section{[Insert Table 4 about here]}

On the whole, our results show that banks adjust to their target capital ratio differently when they are controlled by a shareholder without or with excess control rights. Particularly, banks with excess control rights do not raise equity to adjust to the target. Instead, they rely on earnings retention and sharply reduce their expansion, particularly in lending. Our findings also show that banks without excess control rights adjust to the target -by issuing equitywithout slowing their lending activities. Our results are consistent with Admati, DeMarzo, Hellwig, and Pfleiderer (2010) who argue that banks should be able to expand their lending even if they had to increase their regulatory capital as long as there is no reluctance to issue equity due to specific governance arrangements within the bank. Our findings show that such reluctance is possible and can effectively affect lending for a large number of banks in Europe.

We now go further by analyzing the conditions under which the fear of control dilution is more or less pronounced with possibly stronger implications.

\subsection{Factors affecting the link between excess control rights and capital ratio adjustment}

Our main results support the conjecture that the ultimate controlling shareholders with excess control rights avoid issuing equity and instead draw on earnings and decrease their assets and particularly their loans to increase the capital ratio, possibly to preserve their 
control power. To take our investigation further, we consider some factors that might strengthen or weaken the relationship between excess control rights and the bank's adjustment process towards the target: (i) the type of the largest ultimate controlling shareholder, (ii) the level of shareholder protection rights, and (iii) the 2008 global financial crisis. ${ }^{29}$

\subsubsection{Largest ultimate controlling owner type}

Incentives to extract private benefits of control can vary across different types of controlling shareholders. As argued by Villalonga and Amit (2006), if the controlling shareholder is a widely held institution (bank, industrial firm, mutual fund and so on), the private benefits of control are diluted among multiple owners and as a consequence, the incentives to expropriate are weak. If, however, the controlling shareholder is a family or a state, the incentives for expropriation might be stronger since families and the state are more able to efficiently divert benefits to themselves. ${ }^{30}$ Thus, we examine whether the reluctance to raise equity and the reliance on earnings retention and assets downsizing are more pronounced for particular types of ultimate controlling owners.

For this purpose, we classify banks into three categories depending on their ownership type: family- (Family) and state-controlled (State) banks and the category Other which is the removed category in our model. ${ }^{31}$ The estimation results are presented in Table 5. Our previous result indicating that banks with excess control rights do not increase their Tier 1 capital and, instead, draw on earnings and shrink their assets by mainly cutting their lending, only holds for family-controlled banks. When they are controlled by a state, banks with excess control rights are not found to be reluctant to issue new equity. In our sample, a large part of state ownership comes from government intervention (capital injection and nationalizations) during the 2008 financial crisis which might explain our result.

\footnotetext{
${ }^{29}$ In this section, we estimate this equation: $\mathrm{y}_{\mathrm{i}, \mathrm{t}}=\left[\alpha_{1}+\alpha_{2}\right.$ Factor $+\left(\beta_{1}+\beta_{2}\right.$ Factor $)$ ExcessCR $]$ kSurplus $\mathrm{i}_{\mathrm{i}, \mathrm{t}-1}+$ $\left[\alpha^{\prime}{ }_{1}+\alpha^{\prime}{ }_{2}\right.$ Factor $+\left(\beta^{\prime}{ }_{1}+\beta^{\prime}{ }_{2}\right.$ Factor $)$ ExcessCR $]$ kDeficit ${ }_{\mathrm{i}, \mathrm{t}-1}+\theta \mathrm{y}_{\mathrm{i}, \mathrm{t}-1}+\delta^{\prime} \mathrm{Z}_{\mathrm{i}, \mathrm{t}-1}+\gamma^{\prime} \mathrm{V}_{\mathrm{c}, \mathrm{t}-1}+\alpha_{0}+\omega^{\prime}$ Country $+\tau^{\prime}$ Year $+\varepsilon_{i, t}$, where Factor stands for one of the three variables that are expected to affect the relationship between excess control rights and the adjustment process towards the target capital ratio.

${ }^{30}$ For instance, Claessens, Djankov, Fan, and Lang (2002) find that excess control rights are associated with discounts in family- and state-controlled corporations' value (although the effect is very weak in state-owned firms), but this relation is not significant when the controlling shareholder is a widely held institution. Lin, Ma, Malatesta, and Xuan (2011) find that the positive link between excess control rights and the cost of bank loans is stronger for family-owned firms and weaker for state-owned ones. Cronqvist and Nilsson (2005) find that family-controlled firms avoid equity issuing methods that could dilute their control benefits or impose more monitoring on them.

${ }^{31}$ The category Other includes widely held banks (with no controlling shareholder) and banks controlled by a widely held financial or nonfinancial corporation. This classification is reasonable because banks controlled by a widely held financial or nonfinancial corporation can be classified as widely held themselves (Caprio, Laeven, and Levine, 2007). For simplicity, we also remove banks for which the control chain is a cross-holding (five banks corresponding to 33 observations) since we can neither classify them as widely held banks nor as controlled banks.
} 


\subsubsection{Shareholder protection rights}

As expropriation is more likely to occur in countries with weak shareholder protection rights (La Porta, Lopez-de-Silanes, Shleifer, and Vishny, 2002; Dyck and Zingales, 2004), we conjecture that the largest controlling shareholder with excess control rights might be more reluctant to raise external equity and, instead, will rely more on internal and assets adjustments in these countries. This is because (i) control in such countries is more valuable for the controlling owner as he can divert significant resources and (ii) the fear of becoming a minority shareholder and, in turn, being subject to expropriation, is stronger.

To represent the level of shareholder protection, we use the anti-director index as calculated in Djankov, La Porta, Lopez-de-Silanes, and Shleifer (2008). ${ }^{32}$ In our sample, the index has a median of two and half and ranges from one (Luxembourg) with the weakest protection to five (Spain and the United Kingdom) with the highest level of shareholder protection. We define a dummy variable ShareRight that takes the value of one if the shareholder protection index in a given country is greater than the cross-country median value, and zero otherwise. ${ }^{33}$ The estimation results are presented in Table 6. They show that banks with excess control rights significantly adjust their Tier 1 capital upwards when they are located in a country with strong shareholder protection. But such banks do not at all adjust by issuing equity when they are established in countries with weak shareholder protection rights. Instead, these banks significantly draw on their earnings and decrease their assets (particularly their loans) to adjust their capital ratio upwards. This result is consistent with our prediction: a higher level of shareholder protection rights tempers the fear of control dilution of the controlling shareholders with excess control rights. In countries with strong shareholder rights, banks with excess control rights do externally adjust their Tier 1 capital ratio upwards and do not rely considerably on earnings retention and downsizing.

\footnotetext{
${ }^{32}$ This index is obtained by adding one when: (1) shareholders are allowed to mail in their proxy votes to the firm; (2) shareholders are not required to deposits hares before any general shareholders' meeting; (3) cumulative voting or proportional representation of minorities in the board is allowed; (4) minority shareholders have legal mechanisms against perceived oppression by the board; (5) the minimum percentage of share capital that entitles a shareholder to call for a special shareholders' meeting is no more than $10 \%$; or (6) shareholders have preemptive rights that can be waived only by a shareholders' vote. Although this index has been constructed at the country level from rules in place for publicly listed firms, similar disclosure requirements, approval procedure and facilitation of private litigation are used by owners of privately owned firms to deter managerial misconduct.

${ }^{33}$ We are concerned by potential endogeneity between family/state ownership and the level of shareholder protection and therefore we check the prevalence of state and family ownership in countries with weak and strong shareholder protection. The proportion of observations for banks with excess control rights that have a family or a state as an ultimate controlling owner and that are below their target level is $44 \%$ in countries with relatively weak shareholder protection rights and $38 \%$ in countries with relatively strong rights.
} 


\subsubsection{Financial crisis}

The global financial crisis of 2008 might have influenced the way banks with excess control rights adjust their equity in two opposite directions. On the one hand, banks with excess control rights might have limited the use of external equity capital to adjust their Tier 1 capital ratios because the cost of raising additional capital is higher during downturns. On the other hand, banks controlled via excess control rights are more likely to suffer from tunneling during good times and to benefit from propping up during hard times (Friedman, Johnson, and Mitton, 2003). ${ }^{34}$ Hence, the ultimate controlling shareholders might have transferred funds to these banks during the 2008 crisis. Moreover, because of tighter supervisory scrutiny and market discipline during the crisis, banks with excess control rights might have been under pressure to adjust their capital ratio upwards even via equity issuance.

To test the impact of the 2008 global financial crisis, we define a dummy variable Crisis that takes the value of one if the observation is from 2008 or 2009, and zero otherwise. The estimation results are presented in Table 7. They show that banks with excess control rights do not issue any equity to adjust their Tier 1 ratio upwards during normal times. They rather increase their capital ratio by drawing on earnings and by shrinking their assets and particularly their loans. However, during the 2008 financial crisis these banks significantly increased their Tier 1 capital and they apparently did not draw on earnings or decrease their assets by cutting their loans to adjust their ratio upwards. This suggests that during the crisis, banks with excess control rights increased the use of external capital to adjust upwards for at least one of the reasons discussed above (propping up behavior and/or market/supervisory discipline) and as a consequence their reliance on other adjustment methods (earnings retention and assets adjustment) is no longer significant.

In summary (see Table 8 for an overview of our results), the results show that the presence of excess control rights actually affects the way banks adjust towards the target capital ratio. When they are below the target, banks without excess control rights are found to adjust by issuing equity and by reshuffling their assets without slowing their lending and other activities. When they are above the target, such banks decrease their Tier 1 capital both

\footnotetext{
${ }^{34}$ Friedman, Johnson, and Mitton (2003) define propping up (transfer of funds to the firm) as a negative tunneling behavior (with tunneling defined as a transfer of funds out of the firm) and assumes that the propensity to tunnel is highly correlated with the propensity to prop up, namely that, firms that are likely to be subject to tunneling during upturns are also likely to be propped up during downturns. The reason behind the propping up behavior is that earnings in the future, especially from profit diversion, are valuable for the controlling shareholders and they therefore aim to keep such firms in business and avoid their failure. This allows them to exploit such opportunities in the future.
} 
externally and internally (by repurchasing equity and distributing more dividends) and expand their size and lending. This adjustment behavior -in the absence of excess control rights- is relatively steady across (i) owners type, (ii) weak and strong shareholder protection environment and (iii) normal and distress times. Turning to banks controlled by a shareholder with excess control rights, our results show that they do not increase their lending or reshuffle their assets when their capital ratio moves above the target; instead, they adjust by repurchasing equity possibly to strengthen their controlling power. Such a behavior is relatively steady across owners' type, levels of shareholder protection rights and the state of the economy (normal and distress times). When they need to increase their capital ratio such banks do not issue equity, possibly because their ultimate controlling owners fear control dilution. They rather draw on earnings and shrink their assets by mainly cutting their loans. A closer look shows that such a behavior is only apparent during normal times in family-owned banks or in countries with relatively weak shareholder protection.

Given our findings, the reluctance of banks with excess control rights to raise equity and their reliance on downsizing by cutting their lending might be more pronounced under the Basel III Accords as the Basel Committee on Banking Supervision (BIS, 2010a) has narrowed the definition of Tier 1 capital to ordinary shares only. Because such banks are less able to adjust their Tier 1 capital by issuing equity without diluting voting rights, ${ }^{35}$ they might increase their reliance on internal adjustments and downsizing and specifically by cutting lending. Given their prevalence in Europe and their important contribution to the economy as major lenders, our findings have important policy implications. ${ }^{36}$

\section{Robustness checks}

We perform several regressions to check the robustness of our results ${ }^{37}$ obtained in Sections 4.1 and 4.2. However, to save space we only report (see Appendix B) ${ }^{38}$ the robustness results

\footnotetext{
${ }^{35}$ Preferred shares that do not confer voting rights are no longer eligible as Tier 1 capital under the Basel III agreement, ordinary shares carry voting rights.

${ }^{36}$ Our data indicate that banks with excess control rights are frequent in Europe; they represent around $48 \%$ of the controlled-banks. These banks are more focused on traditional intermediation activities (loans), and contribute up to $50 \%$ of the total loans granted to the economy as a whole.

${ }^{37}$ For each of our robustness checks, we re-estimate the target capital ratio to compute the estimated values of the capital ratio surplus (kSurplus) and shortfall (kDeficit). The results, not reported here but available on request, are almost similar to those obtained in Table A4 in Appendix A.

${ }^{38}$ Note that in all the tables, we only report the results obtained for the variables of interest. Detailed results are available on request.
} 
for Section $4.1 .^{39}$

To test the robustness of our results, we run regressions on two distinct subsamples to differentiate banks without and with excess control rights instead of using interaction terms as in Eq. (6). This check leads to similar findings (see Table B1 in Appendix B).

The period covered by our sample is limited by the availability of data on ownership in Bankscope and Amadeus (9 years). This might limit the effectiveness of a dynamic estimation procedure, namely, the use of a partial capital adjustment model as specified in Eq. (3). Hence, we test the robustness of our results by estimating the values of the target capital ratio using a perfect capital adjustment model as specified in Eq. (1). ${ }^{40}$ This check leaves our main conclusions unchanged (see Panel 1 of Table B2 in Appendix B).

We further exclude from the initial sample banks controlled by more than one large ultimate shareholder (corresponding to 499 observations). The ability and the incentives of a controlling shareholder to expropriate and thus to protect his position might be different in the absence or presence of multiple controlling shareholders. The second largest shareholder could monitor the largest one and impede his tendency to extract private benefits of control. In such a case, the reluctance of the largest shareholder to issue equity (to protect his controlling power) and his reliance on internal funds and downsizing might be less of a concern. If, however, the second largest shareholder colludes with the largest one to form a coalition and render expropriation more efficient (Bennedsen and Wolfenzon, 2000; Maury and Pajuste, 2005; Laeven and Levine, 2008), the reluctance to issue new equity and the reliance on internal funds and downsizing to adjust to the target capital ratio might be more pronounced. This check leads again to similar findings (see Panel 2 of Table B2 in Appendix B).

Since banks from Italy account for more than one third of the sample (this corresponds to 678 observations), we run regressions without Italian banks and obtain almost similar results (see Panel 1 of Table B3 in Appendix B).

We finally increase the control threshold and recalculate ownership variables with a control level of $20 \%$ instead of $10 \%$. This new minimum control threshold changes our database both

\footnotetext{
39 The robustness checks on factors affecting the relationship between the excess control rights and the adjustment process towards the target (Section 4.2) lead to similar conclusions and are available on request.

${ }^{40}$ The Hausman test fails to reject the null hypothesis of the exogeneity of the regressors of Eq. (1). Hence, we estimate this equation using Generalized Least Square estimator (GLS) with robust standards errors.
} 
quantitatively and qualitatively ${ }^{41}$ but our main conclusions are unchanged (see Panel 2 of Table B3 in Appendix B). ${ }^{42}$

\section{Conclusion and policy implications}

The aim of this study is to empirically test whether the divergence between control and cash-flow rights influences banks' capital ratio adjustment behavior. For this purpose, we assemble a novel hand-collected data set on bank ultimate control and ownership structure and work on an unbalanced panel of 341 commercial banks across 17 European countries from 2002 to 2010.

On the whole, the results confirm the conjecture that the bank's decision on how to move to the target capital ratio is different in the presence or absence of excess control rights. On the one hand, when there is no divergence between both rights, we find that banks increase their capital ratio mainly by issuing equity and without slowing their lending activities. Such banks reduce their capital ratio by repurchasing equity (and distributing more dividends) but also by expanding their assets and particularly their lending. In such a case, there appears to be no fear of control dilution of the ultimate controlling shareholders. On the other hand, in the presence of excess control rights, banks are reluctant to issue equity to reach the target but more inclined to repurchase equity when they are above the target. Moreover, such banks are found to counterbalance their reluctance to issue equity by using internal resources and by shrinking their assets and particularly their lending. Furthermore, instead of expanding their assets when they have more equity capital than needed, they adjust by exclusively repurchasing equity. Our findings suggest that the ultimate controlling shareholders with excess control rights curb recapitalization to preserve their controlling position. Further investigation shows that such reluctance to issue new equity -in the presence of excess control rights- and the reliance on internal funds and downsizing to adjust to the target capital ratio hold only if the ultimate controlling shareholder is a family or when the bank is headquartered in a country with weak shareholder protection. However, such behavior was not apparent during the 2008 financial crisis: to move towards their target ratio such banks raised equity without reducing their assets and particularly their lending.

\footnotetext{
${ }^{41}$ With a threshold of $20 \%$ instead of $10 \%$, our database comprises a higher proportion of banks considered as widely held and of banks controlled by another bank. The proportion of family- and state-owned banks is lower. More details on how our ownership variables are affected by increasing the control threshold from $10 \%$ to $20 \%$ are available on request.

${ }^{42}$ Note that we also check the robustness of our results by performing further estimations using this new control threshold (20\%). We run all the checks performed with the data set based on a $10 \%$ threshold. In all cases, our main findings -not reported here and available on request- remain unchanged.
} 
Our findings contribute to the capital structure adjustment literature and, by providing a rationale for credit crunch phenomena driven by specific governance arrangements, have several policy implications. We show that during the $2002-2010$ period covered by the Basel I and II Accords, European banks with and without excess control rights behave differently when they increase Tier 1 regulatory capital to move to their target capital ratios. Consequently, it is important for regulators and supervisors to consider that imposing more stringent capital requirements, particularly by narrowing the definition of Tier 1 capital to ordinary shares, might impact banks differently depending on their ownership pattern and governance structure. According to our results, banks controlled by a shareholder with divergence between both rights are reluctant to raise equity that may dilute the voting power of ultimate owners. Instead, they rely on internal funds (retained earnings) and slow their lending. Consequently, we presume that their propensity to adjust their Tier 1 capital ratio through alternative methods (reducing dividend payments or shrinking assets and particularly loans or risk-weighted assets) might be higher under Basel III Accords because such banks will be less keen to dilute voting rights by issuing more ordinary shares. In the past, banks could strengthen their Tier 1 capital by issuing preferred shares and other types of hybrid capital that carried only cash-flow rights, but this is not permitted under Basel III. Hence, credit crunch phenomena are more likely to occur in the transition from Basel II to Basel III which is expected to be completed in 2019. A better disclosure of banks' ownership structures following the recommendations of the Basel Committee on Banking Supervision (BIS, 2010b) should be encouraged to improve regulatory but also market monitoring and discipline. Increasing the level of shareholder protection is also a solution to temper the aversion of controlling shareholders to external recapitalization (equity issues) and to ensure that banks do not refrain from lending to actually contribute to the real economy. 


\section{References}

Admati, A. R., DeMarzo, P. M., Hellwig, M. F., Pfleiderer, P. C., 2010. Fallacies, irrelevant facts, and myths in the discussion of capital regulation: why bank equity is not expensive. Working paper $\mathrm{N}^{\circ} 86$. Rock Center for Corporate Governance at Stanford University.

Allen, F., Carletti, E., Marquez, R., 2011. Credit market competition and capital regulation. Review of Financial Studies 24, 983-1018.

Almeida, H. V., Wolfenzon, D., 2006. A theory of pyramidal ownership and family business groups. Journal of Finance 61, 2637-2680.

Ayuso, J., Pérez, D., Saurina, J., 2004. Are capital buffers pro-cyclical? evidence from Spanish panel data. Journal of Financial Intermediation 13, 249-264.

Azofra, V., Santamaría, M. (2011). Ownership, control, and pyramids in Spanish commercial banks. Journal of Banking and Finance 35, 1464-1476.

Bennedsen, M., Wolfenzon, D., 2000. The balance of power in closely held corporations. Journal of Financial Economics 58, 113-139.

Berger, A., DeYoung, R., Flannery, M., Lee, D., Öztekin, Ö., 2008. How do large banking organizations manage their capital ratios? Journal of Financial Services Research 34, 123149 .

Berger, A. N., Udell, G. F., 1994. Did risk-based capital allocate bank credit and cause a "credit crunch" in the United States? Journal of Money, Credit and Banking 26, 585-628.

Bertrand, M., Mehta, P., Mullainathan, S., 2002. Ferreting out tunneling: an application to Indian business groups. Quarterly Journal of Economics 117, 121-148.

Bank for International Settlements, 2010a. Group of governors and heads of supervision announces higher global minimum capital standards.Consultative document.

Bank for International Settlements, 2010b. Principles for enhancing bank corporate governance. Consultative document.

Blundell, R., Bond, S., 1998. Initial conditions and moment restrictions in dynamic panel data models. Journal of Econometrics 87, 115-143.

Boubakri, N., Ghouma, H., 2010. Control/ownership structure, creditor rights protection, and the cost of debt financing: international evidence. Journal of Banking and Finance 34, 24812499.

Brinkmann, E. J., Horvitz, P. M., 1995. Risk-based capital standards and the credit crunch. Journal of Money, Credit and Banking 27, 848-63. 
Brewer III, E., Kaufman, G., Wall, L., 2008. Bank capital ratios across countries: why do they vary? Journal of Financial Services Research 34, 177-201.

Byoun, S., 2008. How and when do firms adjust their capital structures toward targets? Journal of Finance 63, 3069-3096.

Caprio, G., Laeven, L., Levine, R., 2007. Governance and bank valuation. Journal of Financial Intermediation 16, 584-617.

Claessens, S., Djankov, S., Fan, J. P. H., Lang, H. P. L., 2002. Disentangling the incentive and entrenchment effects of large shareholdings. Journal of Finance 57, 2741-2771.

Claessens, S., Djankov, S., Lang, H. P. L., 2000. The separation of ownership and control in East Asian corporations. Journal of Financial Economics 58, 81-112.

Claessens, S., Van Horen, N., 2013a. Foreign banks: trends and impact. Journal of Money, Credit and Banking. Forthcoming.

Claessens, S., Van Horen, N., 2013b. Impact of foreign banks. Journal of Financial Perspectives 1, 29-42.

Cronqvist, H., Nilsson, M., 2005. The choice between rights offerings and private equity placements. Journal of Financial Economics 78, 375-407.

Diamond, D. W., Rajan, R. G., 2000. A theory of bank capital. Journal of Finance 55, 24312465 .

Dittmar, A., Thakor, A., 2007. Why do firms issue equity? Journal of Finance 62, 1-54.

Djankov, S., La Porta, R., Lopez-de-Silanes, F., Shleifer, A., 2008. The law and economics of self-dealing. Journal of Financial Economics 88, 430-465.

Dyck, A., Zingales, L., 2004. Private benefits of control: an international comparison. Journal of Finance 59, 537-600.

Faccio, M., Lang, H. P. L., 2002. The ultimate ownership of Western European corporations. Journal of Financial Economics 65, 365-395.

Faccio, M., Lang, H. P. L., Young, L., 2001. Dividends and expropriation. American Economic Review 91, 54-78.

Flannery, M. J., Rangan, K. P., 2008. What caused the bank capital build-up of the 1990s? Review of Finance 12, 391-429.

Friedman, E., Johnson, S., Mitton, T., 2003. Propping and tunneling. Journal of Comparative Economics 31, 732-750. 
Gropp, R., Heider, F., 2011. The determinants of bank capital structure. Review of Finance $15,29-74$.

Haw, I.-M., Ho, S. S. M., Hu, B., Wu, D., 2010. Concentrated control, institutions, and banking sector: an international study. Journal of Banking and Finance 34, 485-497.

Jiang, L., Kim, J.-B., Pang, L., 2011. Control-ownership wedge and investment sensitivity to stock price. Journal of Banking and Finance 35, 2856-2867.

Joh, S. W., 2003. Corporate governance and firm profitability: evidence from Korea before the economic crisis. Journal of Financial Economics 68, 287-322.

Jokipii, T., Milne, A., 2008. The cyclical behaviour of European bank capital buffers. Journal of Banking and Finance 32, 1440-1451.

La Porta, R., Lopez-de-Silanes, F., Shleifer, A., 1999. Corporate ownership around the World. Journal of Finance 54, 471-517.

La Porta, R., Lopez-de-Silanes, F., Shleifer, A., Vishny, R. W., 1998. Law and finance. Journal of Political Economy 106, 1113-1155.

La Porta, R., Lopez-de-Silanes, F., Shleifer, A., Vishny, R. W., 2002. Investor protection and corporate valuation. Journal of Finance 57, 1147-1170.

Laeven, L., Levine, R., 2008. Complex ownership structures and corporate valuations. Review of Financial Studies 21, 579-604.

Laeven, L., Levine, R., 2009. Bank governance, regulation and risk taking. Journal of Financial Economics 93, 259-275.

Lin, C., Ma, Y., Malatesta, P. H., Xuan, Y., 2011. Ownership structure and the cost of corporate borrowing. Journal of Financial Economics 102, 416-431.

Lin, C., Ma, Y., Xuan, Y., 2011. Ownership structure and financial constraints: evidence from a structural estimation. Journal of Financial Economics 102, 416-431.

Lindquist, K.-G., 2004. Banks' buffer capital: how important is risk. Journal of International Money and Finance 23, 493-513.

Marcus, A. J., 1983. The bank capital decision: a time series-cross section analysis. Journal of Finance 38, 1217-1232.

Maury, B., Pajuste, A., 2005. Multiple large shareholders and firm value. Journal of Banking and Finance 29, 1813-1834.

Memmel, C., Raupach, P., 2010. How do banks adjust their capital ratios? Journal of Financial Intermediation 19, 509-528. 
Myers, S. C., Rajan, R. G., 1998. The paradox of liquidity. Quarterly Journal of Economics $113,733-771$.

Nier, E., Baumann, U., 2006. Market discipline, disclosure and moral hazard in banking. Journal of Financial Intermediation 15, 332-361.

Orgler, Y. E., Taggart, R. A., 1983. Implications of corporate capital structure theory for banking institutions. Journal of Money, Credit and Banking 15, 212-221.

Öztekin, Ö., Flannery, M. J., 2012. Institutional determinants of capital structure adjustment speeds. Journal of Financial Economics 103, 88-112.

Petrovic, A., Tutsch, R., 2009. National rescue measures in response to the current financial crisis. Legal working paper $\mathrm{N}^{\circ} 8$. European Central Bank. Frankfurt.

Peek, J., Rosengren, E., 1995. The capital crunch: neither a borrower nor a lender be. Journal of Money, Credit and Banking 27, 625-638.

Shehzad, C. T., de Haan, J., Scholtens, B., 2010. The impact of bank ownership concentration on impaired loans and capital adequacy. Journal of Banking and Finance 34, 399-408.

Villalonga, B., Amit, R., 2006. How do family ownership, control and management affect firm value? Journal of Financial Economics 80, 385-417. 


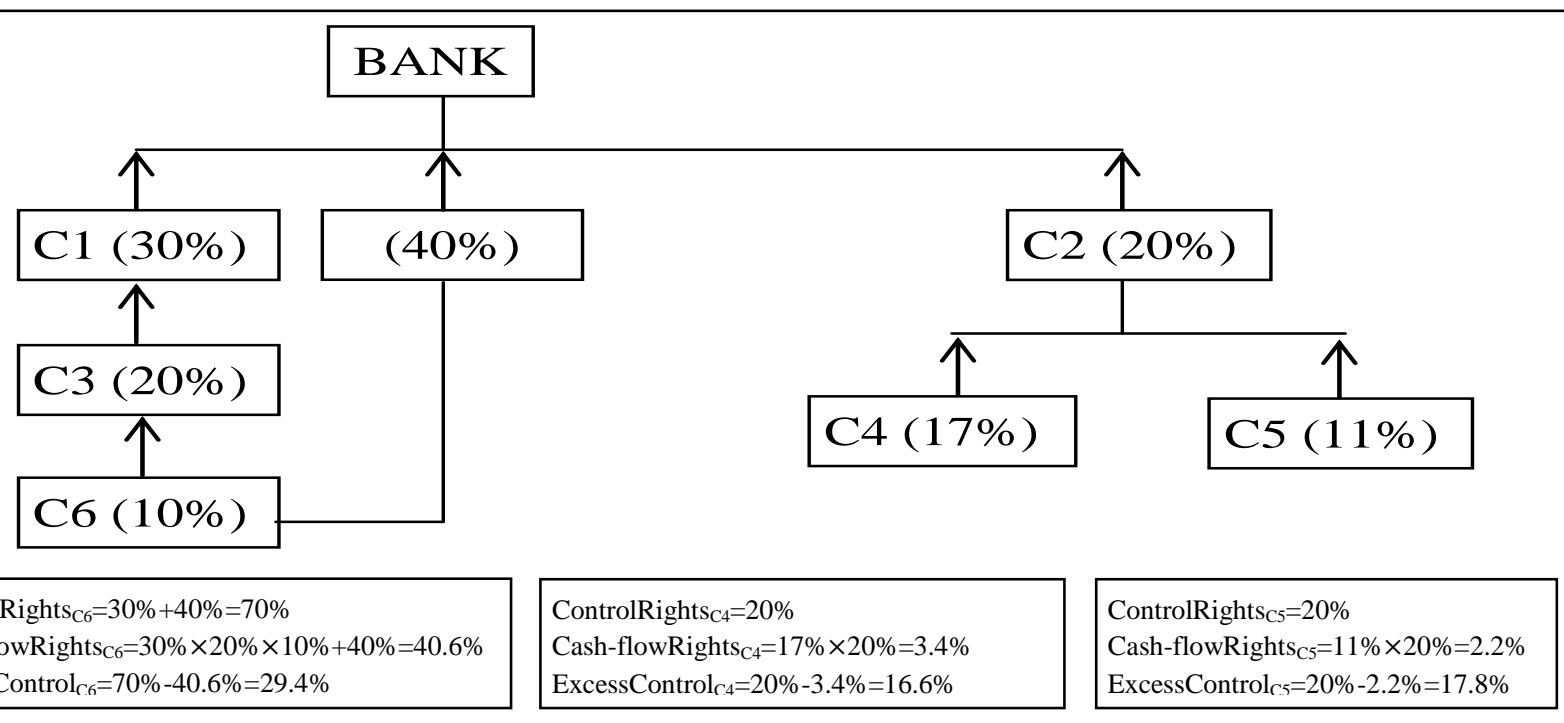

Fig. 1 provides an example of a control chain of a bank (BANK). C refers to each corporation presented in each box. Arrows represent equity stakes held by each corporation in the bank (BANK) or in other corporations in the control chain. ControlRights and CashflowRights respectively indicate voting and cash-flow rights of the three identified ultimate controlling shareholders of the bank (C6, C4 and C5). ExcessControl is the difference between voting and cash-flow rights. Indirect voting rights are computed on the basis of the standard method initially proposed by La Porta, Lopez-de-Silanes, and Shleifer (1999), that is indirect voting rights of an ultimate controlling owner are equal to the percentage of shares held by the last shareholder in the control chain.

Table 1. Statistics on the voting rights, the cash-flow rights and the excess control rights, on average, for the years 2004, 2006 and 2010 (control threshold of 10\%)

\begin{tabular}{|c|c|c|c|c|c|c|}
\hline & \multicolumn{3}{|c|}{ ExcessControl=0 ( 1,416 observations $)$} & \multicolumn{3}{|c|}{ ExcessControl>0 (788 observations) } \\
\hline & ControlRights & Cash-flowRights & ExcessControl & ControlRights & Cash-flowRights & ExcessControl \\
\hline Mean & 50.71 & 50.71 & 0 & 80.22 & 36.34 & 43.89 \\
\hline Median & 50.01 & 50.01 & 0 & 98 & 26.17 & 43.25 \\
\hline Standard deviation & 40.69 & 40.69 & 0 & 26.62 & 29.25 & 30.40 \\
\hline Minimum & 0 & 0 & 0 & 10 & 0.09 & 0.001 \\
\hline Maximum & 100 & 100 & 0 & 100 & 99.74 & 99.41 \\
\hline
\end{tabular}

Subsamples definition: A bank is classified as without excess control rights (ExcessControl=0) if (i) it is controlled by an ultimate owner with equal voting and cash-flow rights, (ii) it is widely held or (iii) if its control chain is a cross-holding. A bank is classified as with excess control rights (ExcessControl>0) if it is controlled by an ultimate owner with greater voting than cash-flow rights.

Variables definition: All variables are expressed in percentages. ControlRights=largest ultimate controlling owner's voting rights if the bank is controlled, ControlRights $=0$ if the bank is widely held or the control chain is a cross-holding; Cash-flowRights=largest ultimate controlling owner's cash-flow rights if the bank is controlled, Cash-flowRights $=0$ if the bank is widely held or the control chain is a cross-holding; ExcessControl=difference between voting and cash-flow rights (ControlRights-Cash-flowRights). 
Table 2. Ultimate ownership type by subsamples, on average, for the years 2004, 2006 and 2010 (control threshold of 10\%)

\begin{tabular}{|c|c|c|c|c|c|c|}
\hline & \multicolumn{3}{|c|}{ ExcessControl=0 ( 1,416 observations $)$} & \multicolumn{3}{|c|}{ ExcessControl>0 (788 observations) } \\
\hline & $\begin{array}{l}\text { Percentage of } \\
\text { observations }\end{array}$ & $\begin{array}{l}\begin{array}{l}\text { Number of } \\
\text { observations }\end{array} \\
\end{array}$ & $\begin{array}{l}\text { Number of } \\
\text { banks }\end{array}$ & $\begin{array}{l}\begin{array}{l}\text { Percentage of } \\
\text { observations }\end{array} \\
\end{array}$ & $\begin{array}{l}\begin{array}{l}\text { Number of } \\
\text { observations }\end{array} \\
\end{array}$ & $\begin{array}{l}\text { Number of } \\
\text { banks }\end{array}$ \\
\hline Bank & 41.88 & 593 & 114 & 17.13 & 135 & 25 \\
\hline Family & 14.76 & 209 & 45 & 30.08 & 237 & 54 \\
\hline State & 3.39 & 48 & 10 & 21.95 & 173 & 44 \\
\hline Institutional & 7.63 & 108 & 25 & 16.12 & 127 & 25 \\
\hline Industry & 2.47 & 35 & 7 & 9.14 & 72 & 14 \\
\hline Foundation & 3.81 & 54 & 12 & 5.58 & 44 & 15 \\
\hline WidelyHeld & 23.73 & 336 & 61 & - & - & - \\
\hline CrossHolding & 2.33 & 33 & 5 & - & - & - \\
\hline
\end{tabular}

Subsamples definition: A bank is classified as without excess control rights (ExcessControl=0) if (i) it is controlled by an ultimate owner with equal voting and cash-flow rights, (ii) it is widely held or (iii) if its control chain is a cross-holding. A bank is classified as with excess control rights (ExcessControl $>0$ ) if it is controlled by an ultimate owner with greater voting than cash-flow rights.

Variables definition: We differentiate banks according to the type of their largest ultimate controlling owner: a bank (Bank); an individual, a family or a manager (Family); a state or a public authority (State); a financial company, an insurance company, a mutual or a pension fund (Institutional); an industrial firm (Industry); a foundation or a research institute (Foundation). WidelyHeld and CrossHolding refer to banks that are respectively widely held and those for which the control chain is a cross-holding.

Table 3. General financial characteristics by ownership, on average, over the 2002-2010 period

\begin{tabular}{|c|c|c|c|c|c|c|c|c|c|}
\hline & Assets & Loans & NPL & ROA & ROE & TotalCapital & Tier1TA & Tier1RWA & Dividend \\
\hline & \multicolumn{9}{|c|}{ ExcessControl=0 (1,416 observations) } \\
\hline Mean & 86,978 & 58.71 & 3.46 & 0.68 & 8.04 & 13.60 & 7.76 & 11.72 & 0.92 \\
\hline Median & 4,772 & 61.81 & 2.15 & 0.60 & 8.78 & 12.40 & 6.65 & 10.10 & 1 \\
\hline Standard deviation & 251,000 & 23.02 & 3.81 & 0.88 & 10.63 & 4.69 & 4.37 & 5.48 & 0.27 \\
\hline Minimum & 57 & 10.03 & 0.05 & -2.98 & -48.96 & 8.05 & 1.50 & 4.90 & 0 \\
\hline \multirow[t]{2}{*}{ Maximum } & $2,202,423$ & 95.94 & 23.61 & 3.32 & 31.44 & 33.78 & 21.83 & 31.70 & 1 \\
\hline & \multicolumn{9}{|c|}{ ExcessControl>0 (788 observations) } \\
\hline Mean & 79,341 & 61.94 & 3.86 & 0.44 & 6.85 & 13.23 & 6.20 & 10.71 & 0.86 \\
\hline Median & 7,899 & 64.47 & 2.43 & 0.45 & 8.38 & 11.80 & 5.34 & 9.13 & 1 \\
\hline Standard deviation & 191,000 & 19.80 & 4.43 & 0.80 & 12.33 & 4.94 & 3.47 & 4.82 & 0.35 \\
\hline Minimum & 68 & 10.07 & 0.05 & -2.93 & -48.94 & 8.08 & 1.44 & 4.92 & 0 \\
\hline Maximum & $1,967,122$ & 95.96 & 23.59 & 3.29 & 31.40 & 33.75 & 21.08 & 31.60 & 1 \\
\hline T-statistics & 0.74 & $-3.45^{* * * *}$ & $-2.13^{* * *}$ & $6.19^{* * * *}$ & $2.39^{* *}$ & $1.69^{*}$ & $8.64^{* * * *}$ & $4.32^{* * *}$ & $3.21^{* * *}$ \\
\hline
\end{tabular}

Subsamples definition: A bank is classified as without excess control rights (ExcessControl=0) if (i) it is controlled by an ultimate owner with equal voting and cash-flow rights, (ii) it is widely held or (iii) if its control chain is a cross-holding. A bank is classified as with excess control rights (ExcessControl>0) if it is controlled by an ultimate owner with greater voting than cash-flow rights.

T-statistics test for the null: "Bank financial characteristics are not different between the subsamples of banks without and with excess control rights"; ${ }^{* * *},{ }^{* * *}$ and ${ }^{*}$ indicate significance at the $1 \%, 5 \%$ and $10 \%$ levels, respectively, for a bilateral test.

Variables definition: All variables are expressed in percentages except Assets which is in millions of Euros and the dummy variable Dividend. Assets=bank's total assets; Loans=ratio of net loans to total assets; NPL=ratio of non-performing loans to gross loans; ROA=return on assets; ROE=return on equity; TotalCapital=risk-based total capital ratio; Tier1TA=ratio of Tier 1 capital to total assets; Tier1RWA=risk-based Tier 1 capital ratio; Dividend=a dummy variable that takes a value of one if the bank pays dividend in a given year, and zero otherwise. 
Table 4: Excess control rights and capital ratio adjustment (2002-2010, GMM)

$$
\begin{aligned}
\mathrm{y}_{\mathrm{i}, \mathrm{t}} & =\left(\alpha_{1}+\beta_{1} \text { ExcessCR }\right) \text { kSurplus }_{\mathrm{i}, \mathrm{t}-1}+\left(\alpha^{\prime}{ }_{1}+\beta_{1}^{\prime}{ }_{1} \text { ExcessCR }\right) \mathrm{kDeficit}_{\mathrm{i}, \mathrm{t}-1}+\theta \mathrm{y}_{\mathrm{i}, \mathrm{t}-1}+\delta^{\prime} \mathrm{Z}_{\mathrm{i}, \mathrm{t}-1}+\gamma^{\prime} \mathrm{V}_{\mathrm{c}, \mathrm{t}-1} \\
& +\alpha_{0}+\omega^{\prime} \text { Country }+\tau^{\prime} \text { Year }+\varepsilon_{\mathrm{i}, \mathrm{t}}
\end{aligned}
$$

\begin{tabular}{|c|c|c|c|c|c|c|c|c|c|c|c|}
\hline \multirow{3}{*}{\multicolumn{2}{|c|}{$\begin{array}{l}\text { Dependent variable y } \\
(1)=\text { Tier1TA, }(2)=\text { Tier1RWA }\end{array}$}} & \multicolumn{4}{|c|}{ Capital adjustment } & \multicolumn{6}{|c|}{ Assets adjustment } \\
\hline & & \multicolumn{2}{|c|}{$\Delta$ Tier1 } & \multicolumn{2}{|c|}{ RetainedEarnings } & \multicolumn{2}{|c|}{$\Delta$ Assets } & \multicolumn{2}{|c|}{$\Delta$ Loans } & \multicolumn{2}{|c|}{$\Delta \mathrm{RWA}$} \\
\hline & & $(1)$ & $(2)$ & $(1)$ & $(2)$ & $(1)$ & $(2)$ & $(1)$ & $(2)$ & $(1)$ & $(2)$ \\
\hline \multicolumn{2}{|l|}{ kSurplus $\left(\alpha_{1}\right)$} & $\begin{array}{l}-0.07^{* *} \\
(0.04)\end{array}$ & $\begin{array}{l}-0.04^{*} \\
(0.08)\end{array}$ & $\begin{array}{l}-0.04^{* * *} \\
(0.02)\end{array}$ & $\begin{array}{l}-0.04^{* *} \\
(0.01)\end{array}$ & $\begin{array}{l}0.80^{* * *} \\
(0.03)\end{array}$ & $\begin{array}{l}0.94^{\text {*** }} \\
(0.04)\end{array}$ & $\begin{array}{l}0.43^{\text {*** }} \\
(0.02)\end{array}$ & $\begin{array}{l}0.51^{\text {** }} \\
(0.03)\end{array}$ & $\begin{array}{l}0.48^{* *} \\
(0.04)\end{array}$ & $\begin{array}{l}0.71^{* * *} \\
(0.01)\end{array}$ \\
\hline \multicolumn{2}{|c|}{ ExcessCR $\times$ kSurplus $\left(\beta_{1}\right)$} & $\begin{array}{l}-0.08 \\
(0.33)\end{array}$ & $\begin{array}{l}-0.02 \\
(0.58)\end{array}$ & $\begin{array}{l}0.02 \\
(0.60)\end{array}$ & $\begin{array}{l}0.01 \\
(0.66)\end{array}$ & $\begin{array}{l}-0.39^{* * *} \\
(0.04)\end{array}$ & $\begin{array}{l}-0.49^{* * *} \\
(0.04)\end{array}$ & $\begin{array}{l}-0.17^{*} \\
(0.05)\end{array}$ & $\begin{array}{l}-0.23^{* *} \\
(0.04)\end{array}$ & $\begin{array}{l}-0.28^{*} \\
(0.06)\end{array}$ & $\begin{array}{l}-0.37^{*} \\
(0.07)\end{array}$ \\
\hline \multicolumn{2}{|l|}{ kDeficit $\left(\alpha_{1}^{\prime}\right)$} & $\begin{array}{l}0.15^{* * *} \\
(0.01)\end{array}$ & $\begin{array}{l}0.09^{* * *} \\
(0.00)\end{array}$ & $\begin{array}{l}0.03 \\
(0.39)\end{array}$ & $\begin{array}{l}0.05^{*} \\
(0.09)\end{array}$ & $\begin{array}{l}-0.39 \\
(0.19)\end{array}$ & $\begin{array}{l}0.13 \\
(0.64)\end{array}$ & $\begin{array}{l}-0.35 \\
(0.30)\end{array}$ & $\begin{array}{l}-0.37 \\
(0.10)\end{array}$ & $\begin{array}{l}-0.22 \\
(0.55)\end{array}$ & $\begin{array}{l}-0.57^{* *} \\
(0.02)\end{array}$ \\
\hline \multicolumn{2}{|c|}{ ExcessCR $\times$ kDeficit $\left(\beta_{1}^{\prime}\right)$} & $\begin{array}{l}-0.10^{* *} \\
(0.02)\end{array}$ & $\begin{array}{l}-0.05^{* *} \\
(0.05)\end{array}$ & $\begin{array}{l}0.05^{*} \\
(0.06)\end{array}$ & $\begin{array}{l}0.03^{*} \\
(0.08)\end{array}$ & $\begin{array}{l}-0.31^{* *} \\
(0.03)\end{array}$ & $\begin{array}{l}-0.84^{* *} \\
(0.02)\end{array}$ & $\begin{array}{l}-0.23^{* *} \\
(0.04)\end{array}$ & $\begin{array}{l}-0.29^{* *} \\
(0.04)\end{array}$ & $\begin{array}{l}-0.27^{*} \\
(0.09)\end{array}$ & $\begin{array}{l}-0.04 \\
(0.22)\end{array}$ \\
\hline \multicolumn{2}{|c|}{ Lagged value of $y\left(y_{i, t-1}\right)$} & $\begin{array}{l}0.03 \\
(0.31)\end{array}$ & $\begin{array}{l}0.02 \\
(0.59)\end{array}$ & $\begin{array}{l}0.40^{* * * *} \\
(0.00)\end{array}$ & $\begin{array}{l}0.37^{* * * *} \\
(0.00)\end{array}$ & $\begin{array}{l}0.11^{\text {**** }} \\
(0.00)\end{array}$ & $\begin{array}{l}0.12^{* * *} \\
(0.00)\end{array}$ & $\begin{array}{l}0.13^{* * *} \\
(0.00)\end{array}$ & $\begin{array}{l}0.15^{* * *} \\
(0.00)\end{array}$ & $\begin{array}{l}0.15^{* * * *} \\
(0.00)\end{array}$ & $\begin{array}{l}0.17^{* * * *} \\
(0.00)\end{array}$ \\
\hline \multicolumn{2}{|l|}{ ExcessCR } & $\begin{array}{l}-0.48^{\text {**** }} \\
(0.00)\end{array}$ & $\begin{array}{l}-0.38^{\text {**** }} \\
(0.01)\end{array}$ & $\begin{array}{l}-0.12 \\
(0.18)\end{array}$ & $\begin{array}{l}-0.11 \\
(0.22)\end{array}$ & $\begin{array}{l}-0.65 \\
(0.79)\end{array}$ & $\begin{array}{l}-0.17 \\
(0.94)\end{array}$ & $\begin{array}{l}-0.55 \\
(0.73)\end{array}$ & $\begin{array}{l}-0.19 \\
(0.89)\end{array}$ & $\begin{array}{l}-0.72 \\
(0.67)\end{array}$ & $\begin{array}{l}-0.19 \\
(0.74)\end{array}$ \\
\hline \multicolumn{2}{|l|}{ Deposits } & $\begin{array}{l}-0.00^{* * *} \\
(0.03)\end{array}$ & $\begin{array}{l}-0.00^{* *} \\
(0.02)\end{array}$ & $\begin{array}{l}0.00^{* * *} \\
(0.04)\end{array}$ & $\begin{array}{l}0.00^{* * *} \\
(0.02)\end{array}$ & $\begin{array}{l}0.00 \\
(0.86)\end{array}$ & $\begin{array}{l}-0.01 \\
(0.73)\end{array}$ & $\begin{array}{l}0.03^{* *} \\
(0.03)\end{array}$ & $\begin{array}{l}0.02 \\
(0.11)\end{array}$ & $\begin{array}{l}0.00 \\
(0.96)\end{array}$ & $\begin{array}{l}0.02 \\
(0.16)\end{array}$ \\
\hline \multicolumn{2}{|l|}{$\log ($ Age $)$} & $\begin{array}{l}-0.01 \\
(0.53)\end{array}$ & $\begin{array}{l}-0.02 \\
(0.23)\end{array}$ & $\begin{array}{l}-0.00 \\
(0.74)\end{array}$ & $\begin{array}{l}-0.01 \\
(0.61)\end{array}$ & $\begin{array}{l}-0.35^{* *} \\
(0.04)\end{array}$ & $\begin{array}{l}-0.29^{*} \\
(0.08)\end{array}$ & $\begin{array}{l}-0.28^{* *} \\
(0.01)\end{array}$ & $\begin{array}{l}-0.20 \\
(0.14)\end{array}$ & $\begin{array}{l}-0.26^{*} \\
(0.08)\end{array}$ & $\begin{array}{l}-0.18 \\
(0.24)\end{array}$ \\
\hline \multicolumn{2}{|l|}{ Rescue } & $\begin{array}{l}0.04 \\
(0.67)\end{array}$ & $\begin{array}{l}0.00 \\
(0.97)\end{array}$ & $\begin{array}{l}0.01 \\
(0.91)\end{array}$ & $\begin{array}{l}0.04 \\
(0.55)\end{array}$ & $\begin{array}{l}1.89 \\
(0.16)\end{array}$ & $\begin{array}{l}1.08 \\
(0.47)\end{array}$ & $\begin{array}{l}1.07 \\
(0.18)\end{array}$ & $\begin{array}{l}0.14 \\
(0.86)\end{array}$ & $\begin{array}{l}0.76 \\
(0.50)\end{array}$ & $\begin{array}{l}0.08 \\
(0.94)\end{array}$ \\
\hline \multicolumn{2}{|l|}{ CrossListed } & $\begin{array}{l}0.03^{* *} \\
(0.02)\end{array}$ & $\begin{array}{l}0.03^{* * * *} \\
(0.00)\end{array}$ & $\begin{array}{l}-0.00 \\
(0.89)\end{array}$ & $\begin{array}{l}0.00 \\
(0.94)\end{array}$ & $\begin{array}{l}0.22^{*} \\
(0.05)\end{array}$ & $\begin{array}{l}0.16 \\
(0.24)\end{array}$ & $\begin{array}{l}0.08 \\
(0.35)\end{array}$ & $\begin{array}{l}0.08 \\
(0.44)\end{array}$ & $\begin{array}{l}0.32^{*} \\
(0.08)\end{array}$ & $\begin{array}{l}-0.33 \\
(0.20)\end{array}$ \\
\hline \multicolumn{2}{|l|}{ Merger } & $\begin{array}{l}0.03 \\
(0.67)\end{array}$ & $\begin{array}{l}0.03 \\
(0.64)\end{array}$ & $\begin{array}{l}0.01 \\
(0.85)\end{array}$ & $\begin{array}{l}0.01 \\
(0.79)\end{array}$ & $\begin{array}{l}0.41 \\
(0.70)\end{array}$ & $\begin{array}{l}0.66 \\
(0.58)\end{array}$ & $\begin{array}{l}1.42^{*} \\
(0.08)\end{array}$ & $\begin{array}{l}1.40^{*} \\
(0.09)\end{array}$ & $\begin{array}{l}0.02 \\
(0.99)\end{array}$ & $\begin{array}{l}1.01 \\
(0.27)\end{array}$ \\
\hline \multicolumn{2}{|c|}{ 3MInterbankRate } & $\begin{array}{l}0.03 \\
(0.59)\end{array}$ & $\begin{array}{l}0.03 \\
(0.58)\end{array}$ & $\begin{array}{l}-0.11^{* * * *} \\
(0.00)\end{array}$ & $\begin{array}{l}-0.11^{* * * *} \\
(0.00)\end{array}$ & $\begin{array}{l}-2.11^{* * *} \\
(0.00)\end{array}$ & $\begin{array}{l}-2.37^{* * * *} \\
(0.00)\end{array}$ & $\begin{array}{l}-1.91^{* * *} \\
(0.00)\end{array}$ & $\begin{array}{l}-2.09^{* * *} \\
(0.00)\end{array}$ & $\begin{array}{l}-1.44^{\text {**** }} \\
(0.00)\end{array}$ & $\begin{array}{l}-1.59^{* * *} \\
(0.00)\end{array}$ \\
\hline \multicolumn{2}{|l|}{ GDPGrowth } & $\begin{array}{l}0.01^{* * *} \\
(0.05)\end{array}$ & $\begin{array}{l}0.01^{*} \\
(0.10)\end{array}$ & $\begin{array}{l}0.01^{*} \\
(0.05)\end{array}$ & $\begin{array}{l}0.00 \\
(0.48)\end{array}$ & $\begin{array}{l}0.26^{* *} \\
(0.02)\end{array}$ & $\begin{array}{l}0.24^{* *} \\
(0.03)\end{array}$ & $\begin{array}{l}0.18^{* * *} \\
(0.00)\end{array}$ & $\begin{array}{l}0.20^{* * * *} \\
(0.00)\end{array}$ & $\begin{array}{l}0.15^{*} \\
(0.05)\end{array}$ & $\begin{array}{l}0.17^{* *} \\
(0.03)\end{array}$ \\
\hline \multicolumn{2}{|l|}{ StockTraded } & $\begin{array}{l}0.00 \\
(0.56)\end{array}$ & $\begin{array}{l}0.00 \\
(0.27)\end{array}$ & $\begin{array}{l}0.00 \\
(0.25)\end{array}$ & $\begin{array}{l}0.00 \\
(0.27)\end{array}$ & $\begin{array}{l}0.01 \\
(0.28)\end{array}$ & $\begin{array}{l}0.02 \\
(0.10)\end{array}$ & $\begin{array}{l}0.00 \\
(0.71)\end{array}$ & $\begin{array}{l}0.01 \\
(0.14)\end{array}$ & $\begin{array}{l}0.00 \\
(0.97)\end{array}$ & $\begin{array}{l}0.00 \\
(0.66)\end{array}$ \\
\hline \multicolumn{2}{|l|}{ Intercept } & $\begin{array}{l}0.25 \\
(0.28)\end{array}$ & $\begin{array}{l}0.24 \\
(0.32)\end{array}$ & $\begin{array}{l}0.57^{* * * *} \\
(0.00)\end{array}$ & $\begin{array}{l}0.60^{* * * *} \\
(0.00)\end{array}$ & $\begin{array}{l}14.19^{* * * *} \\
(0.00)\end{array}$ & $\begin{array}{l}14.02^{\text {*** }} \\
(0.00)\end{array}$ & $\begin{array}{l}8.52^{* * *} \\
(0.00)\end{array}$ & $\begin{array}{l}9.54^{* * * *} \\
(0.00)\end{array}$ & $\begin{array}{l}8.65^{* * *} \\
(0.00)\end{array}$ & $\begin{array}{l}9.09^{\text {**** }} \\
(0.00)\end{array}$ \\
\hline \multicolumn{2}{|c|}{ Number of observations } & $\begin{array}{l}2,204 \\
341\end{array}$ & $\begin{array}{l}2,204 \\
341\end{array}$ & $\begin{array}{l}2,204 \\
341\end{array}$ & $\begin{array}{l}2,204 \\
341\end{array}$ & $\begin{array}{l}2,204 \\
341\end{array}$ & $\begin{array}{l}2,204 \\
341\end{array}$ & $\begin{array}{l}2,204 \\
341\end{array}$ & $\begin{array}{l}2,204 \\
341\end{array}$ & $\begin{array}{l}2,204 \\
341\end{array}$ & $\begin{array}{l}2,204 \\
341\end{array}$ \\
\hline Hansen test: & $\begin{array}{l}\text { Statistic } \\
\text { P-value }\end{array}$ & $\begin{array}{l}186.69 \\
(0.11)\end{array}$ & $\begin{array}{l}186.67 \\
(0.11)\end{array}$ & $\begin{array}{l}186.17 \\
(0.14)\end{array}$ & $\begin{array}{l}187.00 \\
(0.11)\end{array}$ & $\begin{array}{l}173.76 \\
(0.29)\end{array}$ & $\begin{array}{l}177.29 \\
(0.23)\end{array}$ & $\begin{array}{l}182.07 \\
(0.16)\end{array}$ & $\begin{array}{l}179.22 \\
(0.13)\end{array}$ & $\begin{array}{l}184.71 \\
(0.12)\end{array}$ & $\begin{array}{l}172.10 \\
(0.32)\end{array}$ \\
\hline AR2 test: & $\begin{array}{l}\text { Statistic } \\
\text { P-value }\end{array}$ & $\begin{array}{l}0.07 \\
(0.75)\end{array}$ & $\begin{array}{l}-0.02 \\
(0.78)\end{array}$ & $\begin{array}{l}-0.13 \\
(0.70)\end{array}$ & $\begin{array}{l}-0.05 \\
(0.76)\end{array}$ & $\begin{array}{l}1.15 \\
(0.25)\end{array}$ & $\begin{array}{l}1.24 \\
(0.21)\end{array}$ & $\begin{array}{l}0.73 \\
(0.46)\end{array}$ & $\begin{array}{l}0.63 \\
(0.53)\end{array}$ & $\begin{array}{l}1.19 \\
(0.25)\end{array}$ & $\begin{array}{l}1.16 \\
(0.16)\end{array}$ \\
\hline Fitted target & $\begin{array}{l}\text { : Mean } \\
\text { Maximum } \\
\text { Minimum }\end{array}$ & $\begin{array}{l}7.02 \\
14.92 \\
1.70\end{array}$ & $\begin{array}{l}11.53 \\
24.87 \\
4.08\end{array}$ & $\begin{array}{l}7.02 \\
14.92 \\
1.70\end{array}$ & $\begin{array}{l}11.53 \\
24.87 \\
4.08\end{array}$ & $\begin{array}{l}7.02 \\
14.92 \\
1.70\end{array}$ & $\begin{array}{l}11.53 \\
24.87 \\
4.08\end{array}$ & $\begin{array}{l}7.02 \\
14.92 \\
1.70\end{array}$ & $\begin{array}{l}11.53 \\
24.87 \\
4.08\end{array}$ & $\begin{array}{l}7.02 \\
14.92 \\
1.70\end{array}$ & $\begin{array}{l}11.53 \\
24.87 \\
4.08\end{array}$ \\
\hline $\begin{array}{l}\alpha_{1}+\beta_{1} \\
\text { Wald test (P- }\end{array}$ & & $\begin{array}{l}-0.15^{* *} \\
(0.02)\end{array}$ & $\begin{array}{l}-0.06^{* *} \\
(0.03)\end{array}$ & $\begin{array}{l}-0.02 \\
(0.28)\end{array}$ & $\begin{array}{l}-0.03^{*} \\
(0.06)\end{array}$ & $\begin{array}{l}0.41 \\
(0.44)\end{array}$ & $\begin{array}{l}0.45 \\
(0.73)\end{array}$ & $\begin{array}{l}0.26 \\
(0.44)\end{array}$ & $\begin{array}{l}0.28 \\
(0.42)\end{array}$ & $\begin{array}{l}0.20 \\
(0.41)\end{array}$ & $\begin{array}{l}0.34 \\
(0.17)\end{array}$ \\
\hline $\begin{array}{l}\alpha_{1}^{\prime}+\beta_{1}^{\prime} \\
\text { Wald test (P- }\end{array}$ & ue) & $\begin{array}{l}0.05 \\
(0.17)\end{array}$ & $\begin{array}{l}0.04 \\
(0.13)\end{array}$ & $\begin{array}{l}0.08^{* * *} \\
(0.03)\end{array}$ & $\begin{array}{l}0.08^{* * *} \\
(0.05)\end{array}$ & $\begin{array}{l}-0.70^{*} \\
(0.06)\end{array}$ & $\begin{array}{l}-0.71^{* *} \\
(0.03)\end{array}$ & $\begin{array}{l}-0.58^{*} \\
(0.08)\end{array}$ & $\begin{array}{l}-0.66^{* *} \\
(0.02)\end{array}$ & $\begin{array}{l}-0.49^{*} \\
(0.08)\end{array}$ & $\begin{array}{l}-0.61^{* *} \\
(0.02)\end{array}$ \\
\hline
\end{tabular}

Variables definition: $\Delta$ Tier1=annual change in Tier 1 capital less current retained earnings/average assets; RetainedEarnings $=$ current net income less current dividend payment/average assets; $\Delta$ Assets=annual change in total assets/average assets; $\Delta$ Loans=annual change in net loans/average assets; $\Delta \mathrm{RWA}=$ annual change in risk-weighted assets/average assets; average assets=(total assets $\mathrm{t}_{\mathrm{t}}+$ total assets $\left._{\mathrm{t}-1}\right) / 2$; Tier1TA and Tier1RWA are respectively nonrisk- and risk-based Tier 1 capital ratios; kSurplus=absolute value of the gap between the target and the lagged Tier 1 ratios when the bank is above its target, and zero otherwise; ExcessCR=dummy equal to one if control rights are greater than cash-flow rights, and zero otherwise; kDeficit=absolute value of the gap between the target and the lagged Tier 1 ratios when the bank is below its target, and zero otherwise; Deposits=ratio of total customer deposits to total assets; Log(Age)=natural logarithm of bank age; CrossListed=index equal to the number of stock markets on which the bank is listed, and zero if the bank is privately owned; Rescue=dummy equal to one if the bank was rescued during the 2008 financial crisis, and zero otherwise; Merger=dummy equal to one if the bank experienced a merger-acquisition event during the sample period, and zero otherwise; 3 MInterbankRate=three months interbank rate; GDPGrowth=real gross domestic product growth rate; StockTraded=value of listed shares to GDP ratio. Country and Year dummies are included but not reported. Hansen test=test of exogeneity of all instruments as a group; AR2 test=second order residual autocorrelation test. P-values based on robust standard errors are shown in parentheses. ${ }^{* * *}$ and ${ }^{* * *}$ indicate statistical significance at the $10 \%, 5 \%$ and $1 \%$ levels respectively. 
Table 5: Excess control rights and capital ratio adjustment: ownership type (2002-2010, GMM)

$\mathrm{y}_{\mathrm{i}, \mathrm{t}}=\left[\alpha_{1}+\alpha_{2}\right.$ Family $+\alpha_{3}$ State $+\left(\beta_{1}+\beta_{2}\right.$ Family $+\beta_{3}$ State $)$ ExcessCR $]$ kSurplus ${ }_{\mathrm{i}, \mathrm{t}-1}+\left[\alpha^{\prime}{ }_{1}+\alpha^{\prime}{ }_{2}\right.$ Family $+\alpha^{\prime}{ }_{3}$ State $+\left(\beta_{1}^{\prime}+\beta_{2}^{\prime}\right.$ Family $+\beta_{3}^{\prime}$ State) ExcessCR $]$ kDeficit ${ }_{i, \mathrm{t}-1}+\theta \mathrm{y}_{\mathrm{i}, \mathrm{t}-1}+\delta^{\prime} \mathrm{Z}_{\mathrm{i}, \mathrm{t}-1}+\gamma^{\prime} \mathrm{V}_{\mathrm{c}, \mathrm{t}-1}+\alpha_{0}+\omega^{\prime}$ Country $+\tau^{\prime}$ Year $+\varepsilon_{\mathrm{i}, \mathrm{t}}$

\begin{tabular}{|c|c|c|c|c|c|c|c|c|c|c|c|}
\hline \multirow{3}{*}{\multicolumn{2}{|c|}{$\begin{array}{l}\text { Dependent variable y } \\
\text { (1)=Tier1TA, }(2)=\text { Tier1RWA }\end{array}$}} & \multicolumn{4}{|c|}{ Capital adjustment } & \multicolumn{6}{|c|}{ Assets adjustment } \\
\hline & & \multicolumn{2}{|c|}{$\Delta$ Tier1 } & \multicolumn{2}{|c|}{ RetainedEarnings } & \multicolumn{2}{|c|}{$\Delta$ Assets } & \multicolumn{2}{|c|}{$\Delta$ Loans } & \multicolumn{2}{|c|}{$\Delta \mathrm{RWA}$} \\
\hline & & $(1)$ & (2) & $(1)$ & (2) & $(1)$ & $(2)$ & $(1)$ & $(2)$ & $(1)$ & $(2)$ \\
\hline \multicolumn{2}{|c|}{ kSurplus $\left(\alpha_{1}\right)$} & $\begin{array}{l}-0.11^{\text {*** }} \\
(0.02)\end{array}$ & $\begin{array}{l}-0.06^{* *} \\
(0.05)\end{array}$ & $\begin{array}{l}-0.07^{* *} \\
(0.02)\end{array}$ & $\begin{array}{l}-0.05^{* *} \\
(0.03)\end{array}$ & $\begin{array}{l}0.75^{* *} \\
(0.03)\end{array}$ & $\begin{array}{l}0.82^{* *} \\
(0.05)\end{array}$ & $\begin{array}{l}0.31^{*} \\
(0.05)\end{array}$ & $\begin{array}{l}0.46^{* *} \\
(0.02)\end{array}$ & $\begin{array}{l}0.41^{* *} \\
(0.04)\end{array}$ & $\begin{array}{l}0.61^{* *} \\
(0.03)\end{array}$ \\
\hline \multicolumn{2}{|c|}{ Family $\times$ kSurplus $\left(\alpha_{2}\right)$} & $\begin{array}{l}0.07 \\
(0.27)\end{array}$ & $\begin{array}{l}0.01 \\
(0.85)\end{array}$ & $\begin{array}{l}0.02 \\
(0.21)\end{array}$ & $\begin{array}{l}0.02 \\
(0.18)\end{array}$ & $\begin{array}{l}0.14 \\
(0.37)\end{array}$ & $\begin{array}{l}0.15 \\
(0.16)\end{array}$ & $\begin{array}{l}0.18 \\
(0.26)\end{array}$ & $\begin{array}{l}0.12 \\
(0.36)\end{array}$ & $\begin{array}{l}0.16 \\
(0.34)\end{array}$ & $\begin{array}{l}0.14 \\
(0.32)\end{array}$ \\
\hline \multicolumn{2}{|c|}{ State $\times$ kSurplus $\left(\alpha_{3}\right)$} & $\begin{array}{l}0.07 \\
(0.33)\end{array}$ & $\begin{array}{l}-0.01 \\
(0.89)\end{array}$ & $\begin{array}{l}-0.01 \\
(0.36)\end{array}$ & $\begin{array}{l}0.01 \\
(0.24)\end{array}$ & $\begin{array}{l}0.04 \\
(0.73)\end{array}$ & $\begin{array}{l}0.20 \\
(0.21)\end{array}$ & $\begin{array}{l}0.06 \\
(0.30)\end{array}$ & $\begin{array}{l}0.08 \\
(0.66)\end{array}$ & $\begin{array}{l}0.08 \\
(0.44)\end{array}$ & $\begin{array}{l}0.16 \\
(0.58)\end{array}$ \\
\hline \multicolumn{2}{|c|}{ ExcessCR $\times$ kSurplus $\left(\beta_{1}\right)$} & $\begin{array}{l}-0.04 \\
(0.67)\end{array}$ & $\begin{array}{l}-0.00 \\
(0.95)\end{array}$ & $\begin{array}{l}-0.01 \\
(0.12)\end{array}$ & $\begin{array}{l}-0.01 \\
(0.75)\end{array}$ & $\begin{array}{l}-0.40 \\
(0.27)\end{array}$ & $\begin{array}{l}-0.39 \\
(0.51)\end{array}$ & $\begin{array}{l}-0.11 \\
(0.88)\end{array}$ & $\begin{array}{l}-0.15 \\
(0.70)\end{array}$ & $\begin{array}{l}-0.20 \\
(0.35)\end{array}$ & $\begin{array}{l}-0.29 \\
(0.26)\end{array}$ \\
\hline \multicolumn{2}{|c|}{ ExcessCR $\times$ Family $\times$ kSurplus $\left(\beta_{2}\right)$} & $\begin{array}{l}-0.06^{*} \\
(0.08)\end{array}$ & $\begin{array}{l}-0.07^{*} \\
(0.07)\end{array}$ & $\begin{array}{l}0.04^{*} \\
(0.05)\end{array}$ & $\begin{array}{l}0.01 \\
(0.20)\end{array}$ & $\begin{array}{l}-0.07 \\
(0.52)\end{array}$ & $\begin{array}{l}-0.17 \\
(0.20)\end{array}$ & $\begin{array}{l}-0.06 \\
(0.72)\end{array}$ & $\begin{array}{l}-0.16 \\
(0.79)\end{array}$ & $\begin{array}{l}-0.15 \\
(0.92)\end{array}$ & $\begin{array}{l}-0.11 \\
(0.40)\end{array}$ \\
\hline \multicolumn{2}{|c|}{ ExcessCR $\times$ State $\times$ kSurplus $\left(\beta_{3}\right)$} & $\begin{array}{l}-0.02 \\
(0.33)\end{array}$ & $\begin{array}{l}-0.02 \\
(0.65)\end{array}$ & $\begin{array}{l}-0.12 \\
(0.31)\end{array}$ & $\begin{array}{l}-0.01 \\
(0.14)\end{array}$ & $\begin{array}{l}0.06 \\
(0.50)\end{array}$ & $\begin{array}{l}-0.15 \\
(0.17)\end{array}$ & $\begin{array}{l}0.03 \\
(0.66)\end{array}$ & $\begin{array}{l}-0.08 \\
(0.28)\end{array}$ & $\begin{array}{l}-0.09 \\
(0.45)\end{array}$ & $\begin{array}{l}-0.13 \\
(0.19)\end{array}$ \\
\hline \multicolumn{2}{|l|}{ kDeficit $\left(\alpha_{1}^{\prime}\right)$} & $\begin{array}{l}0.16^{* *} \\
(0.01)\end{array}$ & $\begin{array}{l}0.08^{* * * *} \\
(0.00)\end{array}$ & $\begin{array}{l}0.03 \\
(0.33)\end{array}$ & $\begin{array}{l}0.05^{*} \\
(0.08)\end{array}$ & $\begin{array}{l}-0.37 \\
(0.12)\end{array}$ & $\begin{array}{l}0.08 \\
(0.78)\end{array}$ & $\begin{array}{l}-0.42 \\
(0.19)\end{array}$ & $\begin{array}{l}-0.39 \\
(0.18)\end{array}$ & $\begin{array}{l}-0.31 \\
(0.16)\end{array}$ & $\begin{array}{l}-0.53^{* *} \\
(0.01)\end{array}$ \\
\hline \multicolumn{2}{|c|}{ Family $\times$ kDeficit $\left(\alpha_{2}^{\prime}\right)$} & $\begin{array}{l}0.11 \\
(0.15)\end{array}$ & $\begin{array}{l}0.07 \\
(0.10)\end{array}$ & $\begin{array}{l}0.01 \\
(0.84)\end{array}$ & $\begin{array}{l}0.01 \\
(0.47)\end{array}$ & $\begin{array}{l}0.06 \\
(0.38)\end{array}$ & $\begin{array}{l}0.07 \\
(0.49)\end{array}$ & $\begin{array}{l}0.06 \\
(0.26)\end{array}$ & $\begin{array}{l}-0.07 \\
(0.81)\end{array}$ & $\begin{array}{l}0.14 \\
(0.48)\end{array}$ & $\begin{array}{l}-0.03 \\
(0.41)\end{array}$ \\
\hline \multicolumn{2}{|c|}{ State $\times$ kDeficit $\left(\alpha^{\prime}\right)$} & $\begin{array}{l}0.02 \\
(0.89)\end{array}$ & $\begin{array}{l}-0.03 \\
(0.36)\end{array}$ & $\begin{array}{l}-0.04 \\
(0.42)\end{array}$ & $\begin{array}{l}-0.00 \\
(0.99)\end{array}$ & $\begin{array}{l}0.03 \\
(0.78)\end{array}$ & $\begin{array}{l}0.04 \\
(0.61)\end{array}$ & $\begin{array}{l}0.06 \\
(0.25)\end{array}$ & $\begin{array}{l}-0.06 \\
(0.82)\end{array}$ & $\begin{array}{l}0.03 \\
(0.70)\end{array}$ & $\begin{array}{l}-0.08 \\
(0.40)\end{array}$ \\
\hline \multicolumn{2}{|c|}{ ExcessCR $\times$ kDeficit $\left(\beta_{1}^{\prime}\right)$} & $\begin{array}{l}-0.08 \\
(0.24)\end{array}$ & $\begin{array}{l}-0.02 \\
(0.26)\end{array}$ & $\begin{array}{l}0.04 \\
(0.35)\end{array}$ & $\begin{array}{l}0.00 \\
(0.91)\end{array}$ & $\begin{array}{l}-0.12 \\
(0.20)\end{array}$ & $\begin{array}{l}-0.50 \\
(0.29)\end{array}$ & $\begin{array}{l}-0.06 \\
(0.70)\end{array}$ & $\begin{array}{l}-0.10 \\
(0.16)\end{array}$ & $\begin{array}{l}-0.05 \\
(0.48)\end{array}$ & $\begin{array}{l}-0.05 \\
(0.21)\end{array}$ \\
\hline \multicolumn{2}{|c|}{ ExcessCR $\times$ Family $\times$ kDeficit $\left(\beta^{\prime}{ }_{2}\right)$} & $\begin{array}{l}-0.17^{* *} \\
(0.04)\end{array}$ & $\begin{array}{l}-0.10^{* * *} \\
(0.03)\end{array}$ & $\begin{array}{l}-0.00 \\
(0.93)\end{array}$ & $\begin{array}{l}0.02^{*} \\
(0.09)\end{array}$ & $\begin{array}{l}-0.52^{* *} \\
(0.02)\end{array}$ & $\begin{array}{l}-0.67^{* * *} \\
(0.01)\end{array}$ & $\begin{array}{l}-0.29^{* * *} \\
(0.05)\end{array}$ & $\begin{array}{l}-0.39^{* * *} \\
(0.03)\end{array}$ & $\begin{array}{l}-0.45^{*} \\
(0.07)\end{array}$ & $\begin{array}{l}-0.11 \\
(0.10)\end{array}$ \\
\hline \multicolumn{2}{|c|}{ ExcessCR $\times$ State $\times$ kDeficit $\left(\beta_{3}^{\prime}\right)$} & $\begin{array}{l}-0.02 \\
(0.77) \\
\end{array}$ & $\begin{array}{l}0.08^{* * *} \\
(0.03)\end{array}$ & $\begin{array}{l}-0.05 \\
(0.50) \\
\end{array}$ & $\begin{array}{l}-0.03 \\
(0.90)\end{array}$ & $\begin{array}{l}-0.13 \\
(0.15) \\
\end{array}$ & $\begin{array}{l}-0.17 \\
(0.22) \\
\end{array}$ & $\begin{array}{l}-0.12 \\
(0.31)\end{array}$ & $\begin{array}{l}0.11^{* * *} \\
(0.03)\end{array}$ & $\begin{array}{l}-0.09 \\
(0.41)\end{array}$ & $\begin{array}{l}0.10 \\
(0.11)\end{array}$ \\
\hline \multicolumn{2}{|c|}{ Control variables } & Yes & Yes & Yes & Yes & Yes & Yes & Yes & Yes & Yes & Yes \\
\hline \multicolumn{2}{|c|}{ Number of observations } & 2,171 & 2,171 & 2,171 & 2,171 & 2,171 & 2,171 & 2,171 & 2,171 & 2,171 & 2,171 \\
\hline \multicolumn{2}{|c|}{ Number of banks } & 336 & 336 & 336 & 336 & 336 & 336 & 336 & 336 & 336 & 336 \\
\hline $\begin{array}{l}\text { Hansen test: } \\
\text { AR2 test: }\end{array}$ & $\begin{array}{l}\text { Statistic } \\
\text { P-value } \\
\text { Statistic } \\
\text { P-value }\end{array}$ & $\begin{array}{l}182.86 \\
(0.13) \\
0.19 \\
(0.85)\end{array}$ & $\begin{array}{l}182.02 \\
(0.14) \\
0.10 \\
(0.92)\end{array}$ & $\begin{array}{l}179.35 \\
(0.12) \\
-0.12 \\
(0.69) \\
\end{array}$ & $\begin{array}{l}176.33 \\
(0.12) \\
0.07 \\
(0.95) \\
\end{array}$ & $\begin{array}{l}186.59 \\
(0.17) \\
1.01 \\
(0.31)\end{array}$ & $\begin{array}{l}187.84 \\
(0.15) \\
1.05 \\
(0.29)\end{array}$ & $\begin{array}{l}188.53 \\
(0.16) \\
0.44 \\
(0.66)\end{array}$ & $\begin{array}{l}186.83 \\
(0.14) \\
-0.10 \\
(0.60) \\
\end{array}$ & $\begin{array}{l}185.83 \\
(0.12) \\
1.04 \\
(0.34) \\
\end{array}$ & $\begin{array}{l}183.15 \\
(0.20) \\
1.22 \\
(0.22) \\
\end{array}$ \\
\hline $\begin{array}{l}\alpha_{1}+\alpha_{2} \\
\text { Wald test (P. }\end{array}$ & lue) & $\begin{array}{l}-0.04^{* * *} \\
(0.05)\end{array}$ & $\begin{array}{l}-0.05^{* *} \\
(0.05)\end{array}$ & $\begin{array}{l}-0.05^{* *} \\
(0.04)\end{array}$ & $\begin{array}{l}-0.03^{*} \\
(0.08)\end{array}$ & $\begin{array}{l}0.89^{* * *} \\
(0.00)\end{array}$ & $\begin{array}{l}0.97^{* * * *} \\
(0.00)\end{array}$ & $\begin{array}{l}0.49^{* *} \\
(0.03)\end{array}$ & $\begin{array}{l}0.58^{* *} \\
(0.01)\end{array}$ & $\begin{array}{l}0.57^{* *} \\
(0.01)\end{array}$ & $\begin{array}{l}0.75^{* * * *} \\
(0.00)\end{array}$ \\
\hline$\alpha_{1}+\alpha_{3}$ & & $-0.04^{*}$ & $-0.07^{* *}$ & $-0.08^{* * *}$ & $-0.04^{* *}$ & $0.79^{* *}$ & $1.02^{* * *}$ & $0.37^{* *}$ & $0.54^{* * *}$ & $0.49^{* * *}$ & $0.77^{* * * *}$ \\
\hline $\begin{array}{l}\text { Wald test (P- } \\
\alpha_{1}+\beta_{1}\end{array}$ & lue) & $\begin{array}{l}(0.06) \\
-0.15^{* *}\end{array}$ & $\begin{array}{l}(0.04) \\
-0.06^{* * *}\end{array}$ & $\begin{array}{l}(0.03) \\
-0.08^{* * *}\end{array}$ & $\begin{array}{l}(0.05) \\
-0.06^{*}\end{array}$ & $\begin{array}{l}(0.01) \\
0.35\end{array}$ & $\begin{array}{l}(0.00) \\
0.43\end{array}$ & $\begin{array}{l}(0.04) \\
0.20\end{array}$ & $\begin{array}{l}(0.02) \\
0.31\end{array}$ & $\begin{array}{l}(0.02) \\
0.21\end{array}$ & $\begin{array}{l}(0.00) \\
0.32\end{array}$ \\
\hline Wald test $(\mathrm{P}$ & lue) & $(0.02)$ & $(0.04)$ & $(0.04)$ & $(0.08)$ & $(0.54)$ & $(0.30)$ & $(0.79)$ & $(0.56)$ & $(0.18)$ & $(0.16)$ \\
\hline$\alpha_{1}+\beta_{1}+\alpha$ & $\beta_{2}$ & $-0.14^{* * *}$ & $-0.12^{* *}$ & -0.02 & -0.03 & 0.42 & 0.41 & 0.32 & 0.27 & 0.22 & 0.35 \\
\hline Wald test $(\mathrm{P}$ & lue) & $(0.02)$ & $(0.03)$ & $(0.49)$ & $(0.21)$ & $(0.18)$ & $(0.47)$ & $(0.67)$ & $(0.50)$ & $(0.34)$ & $(0.29)$ \\
\hline$\alpha_{1}+\beta_{1}+\alpha_{3}$ & & $-0.10^{* *}$ & $-0.09^{* *}$ & $-0.19^{* * *}$ & $-0.06^{* *}$ & 0.45 & 0.48 & 0.29 & 0.31 & 0.20 & 0.35 \\
\hline Wald test $(\mathrm{P}$ & lue) & $(0.03)$ & $(0.04)$ & $(0.03)$ & $(0.05)$ & $(0.15)$ & $(0.25)$ & $(0.53)$ & $(0.43)$ & $(0.30)$ & $(0.19)$ \\
\hline$\alpha_{1}^{\prime}+\alpha_{2}^{\prime}$ & & $0.27^{* * * *}$ & $0.15^{* * *}$ & 0.04 & $0.06^{*}$ & -0.31 & 0.15 & -0.36 & -0.46 & -0.17 & $-0.56^{* * *}$ \\
\hline Wald test $(\mathrm{P}$ & lue) & $(0.00)$ & $(0.00)$ & $(0.15)$ & $(0.09)$ & $(0.17)$ & $(0.58)$ & $(0.26)$ & $(0.13)$ & $(0.32)$ & $(0.01)$ \\
\hline$\alpha_{1}^{\prime}+\alpha_{3}^{\prime}$ & & $0.18^{* * * *}$ & $0.05^{* *}$ & -0.01 & $0.05^{*}$ & -0.34 & 0.12 & -0.36 & -0.45 & -0.28 & $-0.61^{\text {**** }}$ \\
\hline Wald test $(\mathrm{P}$ & lue) & $(0.00)$ & $(0.04)$ & $(0.67)$ & $(0.10)$ & $(0.15)$ & $(0.63)$ & $(0.25)$ & $(0.15)$ & $(0.21)$ & $(0.00)$ \\
\hline$\alpha_{1}^{\prime}+\beta_{1}^{\prime}$ & & $0.08^{* *}$ & $0.06^{* *}$ & $0.07^{*}$ & $0.05^{*}$ & -0.49 & -0.42 & -0.48 & $-0.49^{*}$ & -0.36 & $-0.58^{* *}$ \\
\hline Wald test $(\mathrm{P}$ & lue) & $(0.03)$ & $(0.01)$ & $(0.05)$ & $(0.05)$ & $(0.18)$ & $(0.14)$ & $(0.25)$ & $(0.09)$ & $(0.49)$ & $(0.04)$ \\
\hline$\alpha_{1}^{\prime}+\beta_{1}^{\prime}+c$ & $+\beta_{2}^{\prime}$ & 0.02 & 0.03 & $0.08^{* *}$ & $0.08^{* *}$ & $-0.95^{* *}$ & $-1.02^{* * *}$ & $-0.71^{* * *}$ & $-0.95^{* *}$ & $-0.67^{* * *}$ & $-0.72^{* * *}$ \\
\hline Wald test $(\mathrm{P}$ & lue) & $(0.71)$ & $(0.59)$ & $(0.03)$ & $(0.04)$ & $(0.02)$ & $(0.03)$ & $(0.03)$ & $(0.03)$ & $(0.05)$ & $(0.03)$ \\
\hline$\alpha_{1}^{\prime}+\beta_{1}^{\prime}+c$ & $+\beta_{3}^{\prime}$ & $0.08^{* *}$ & $0.11^{* * *}$ & -0.02 & 0.02 & $-0.59^{*}$ & $-0.55^{*}$ & -0.54 & -0.44 & -0.42 & -0.56 \\
\hline Wald test $(\mathrm{P}$ & lue) & $(0.02)$ & $(0.00)$ & $(0.67)$ & $(0.39)$ & $(0.10)$ & $(0.07)$ & $(0.17)$ & $(0.19)$ & $(0.37)$ & $(0.14)$ \\
\hline
\end{tabular}

Variables definition: $\Delta$ Tier1=annual change in Tier 1 capital less current retained earnings/average assets; RetainedEarnings=current net income less current dividend payment/average assets; $\Delta$ Assets=annual change in total assets/average assets; $\Delta$ Loans=annual change in net loans/average assets; $\Delta \mathrm{RWA}=$ annual change in risk-weighted assets/average assets; average assets $=\left(\right.$ total $_{\text {assets }}+$ total $_{\mathrm{t}}$ assets $\left._{\mathrm{t}-1}\right) / 2$; Tier1TA and Tier1RWA are respectively nonrisk- and risk-based target Tier 1 capital ratios; kSurplus=absolute value of the gap between the target and the lagged Tier 1 ratios when the bank is above its target, and zero otherwise; Family=dummy equal to one if the bank is family-controlled, and zero otherwise; State=dummy equal to one if the bank is state-controlled, and zero otherwise; ExcessCR=dummy equal to one if control rights are greater than cash-flow rights, and zero otherwise; kDeficit=absolute value of the gap between the target and the lagged Tier 1 ratios when the bank is below its target, and zero otherwise. In addition to Family and State dummies, the regressions contain the same control variables as in Table 4 (see their definition in Table A5 in Appendix A). Country and Year dummies are included but not reported. Detailed results are available on request. Hansen test=test of exogeneity of all instruments as a group; AR2 test=second order residual autocorrelation test. P-values based on robust standard errors are shown in parentheses. ${ }^{* * *}$ and ${ }^{* * *}$ indicate statistical significance at the $10 \%, 5 \%$ and $1 \%$ levels respectively. 
Table 6: Excess control rights and capital ratio adjustment: shareholder protection (2002-2010, GMM)

$\mathrm{y}_{\mathrm{i}, \mathrm{t}}=\left[\alpha_{1}+\alpha_{2}\right.$ ShareRight $+\left(\beta_{1}+\beta_{2}\right.$ ShareRight $)$ ExcessCR $]$ kSurplus $\mathrm{i}_{\mathrm{i}, \mathrm{t}-1}+\left[\alpha^{\prime}{ }_{1}+\alpha^{\prime}{ }_{2}\right.$ ShareRight $+\left(\beta^{\prime}{ }_{1}+\right.$ $\beta_{2}^{\prime}$ ShareRight)ExcessCR]kDeficit ${ }_{\mathrm{i}, \mathrm{t}-1}+\theta \mathrm{y}_{\mathrm{i}, \mathrm{t}-1}+\delta^{\prime} \mathrm{Z}_{\mathrm{i}, \mathrm{t}-1}+\gamma^{\prime} \mathrm{V}_{\mathrm{c}, \mathrm{t}-1}+\alpha_{0}+\omega^{\prime}$ Country $+\tau^{\prime}$ Year $+\varepsilon_{\mathrm{i}, \mathrm{t}}$

\begin{tabular}{|c|c|c|c|c|c|c|c|c|c|c|c|}
\hline \multirow{3}{*}{\multicolumn{2}{|c|}{$\begin{array}{l}\text { Dependent variable y } \\
(1)=\text { Tier1TA, }(2)=\text { Tier1RWA }\end{array}$}} & \multicolumn{4}{|c|}{ Capital adjustment } & \multicolumn{6}{|c|}{ Assets adjustment } \\
\hline & & \multicolumn{2}{|c|}{$\Delta$ Tier1 } & \multicolumn{2}{|c|}{ RetainedEarnings } & \multicolumn{2}{|c|}{$\Delta$ Assets } & \multicolumn{2}{|c|}{$\Delta$ Loans } & \multicolumn{2}{|c|}{$\Delta \mathrm{RWA}$} \\
\hline & & (1) & (2) & (1) & (2) & (1) & (2) & (1) & (2) & (1) & (2) \\
\hline \multicolumn{2}{|c|}{ kSurplus $\left(\alpha_{1}\right)$} & $\begin{array}{l}-0.08^{* *} \\
(0.02)\end{array}$ & $\begin{array}{l}-0.07^{*} \\
(0.09)\end{array}$ & $\begin{array}{l}-0.06^{* *} \\
(0.02)\end{array}$ & $\begin{array}{l}-0.06^{* * * *} \\
(0.01)\end{array}$ & $\begin{array}{l}0.72^{* *} \\
(0.01)\end{array}$ & $\begin{array}{l}0.89^{* * *} \\
(0.01)\end{array}$ & $\begin{array}{l}0.33^{*} \\
(0.07)\end{array}$ & $\begin{array}{l}0.43^{* *} \\
(0.05)\end{array}$ & $\begin{array}{l}0.39^{* *} \\
(0.02)\end{array}$ & $\begin{array}{l}0.62^{* * *} \\
(0.04)\end{array}$ \\
\hline \multicolumn{2}{|c|}{ ShareRight $\times$ kSurplus $\left(\alpha_{2}\right)$} & $\begin{array}{l}0.02 \\
(0.10)\end{array}$ & $\begin{array}{l}0.03 \\
(0.22)\end{array}$ & $\begin{array}{l}-0.02 \\
(0.29)\end{array}$ & $\begin{array}{l}0.01 \\
(0.24)\end{array}$ & $\begin{array}{l}0.15 \\
(0.59)\end{array}$ & $\begin{array}{l}0.08 \\
(0.19)\end{array}$ & $\begin{array}{l}0.15 \\
(0.56)\end{array}$ & $\begin{array}{l}0.14 \\
(0.73)\end{array}$ & $\begin{array}{l}0.16 \\
(0.89)\end{array}$ & $\begin{array}{l}0.18 \\
(0.28)\end{array}$ \\
\hline \multicolumn{2}{|c|}{ ExcessCR $\times$ kSurplus $\left(\beta_{1}\right)$} & $\begin{array}{l}-0.08 \\
(0.65)\end{array}$ & $\begin{array}{l}-0.02 \\
(0.90)\end{array}$ & $\begin{array}{l}0.05 \\
(0.15)\end{array}$ & $\begin{array}{l}0.04 \\
(0.17)\end{array}$ & $\begin{array}{l}-0.36 \\
(0.39)\end{array}$ & $\begin{array}{l}-0.48 \\
(0.69)\end{array}$ & $\begin{array}{l}-0.04 \\
(0.50)\end{array}$ & $\begin{array}{l}-0.17 \\
(0.74)\end{array}$ & $\begin{array}{l}-0.18 \\
(0.70)\end{array}$ & $\begin{array}{l}-0.29 \\
(0.19)\end{array}$ \\
\hline \multicolumn{2}{|c|}{ ExcessCR $\times$ ShareRight $\times$ kSurplus $\left(\beta_{1}\right)$} & $\begin{array}{l}0.06 \\
(0.72)\end{array}$ & $\begin{array}{l}0.02 \\
(0.53)\end{array}$ & $\begin{array}{l}-0.03 \\
(0.14)\end{array}$ & $\begin{array}{l}-0.06^{*} \\
(0.10)\end{array}$ & $\begin{array}{l}-0.07 \\
(0.78)\end{array}$ & $\begin{array}{l}-0.02 \\
(0.78)\end{array}$ & $\begin{array}{l}-0.18 \\
(0.19)\end{array}$ & $\begin{array}{l}0.07 \\
(0.97)\end{array}$ & $\begin{array}{l}-0.17 \\
(0.10)\end{array}$ & $\begin{array}{l}-0.16 \\
(0.11)\end{array}$ \\
\hline \multicolumn{2}{|c|}{ kDeficit $\left(\alpha_{1}^{\prime}\right)$} & $\begin{array}{l}0.16^{* *} \\
(0.04)\end{array}$ & $\begin{array}{l}0.07^{* *} \\
(0.04)\end{array}$ & $\begin{array}{l}0.04 \\
(0.45)\end{array}$ & $\begin{array}{l}0.04^{*} \\
(0.08)\end{array}$ & $\begin{array}{l}-0.35 \\
(0.17)\end{array}$ & $\begin{array}{l}-0.09 \\
(0.64)\end{array}$ & $\begin{array}{l}-0.37 \\
(0.17)\end{array}$ & $\begin{array}{l}-0.29 \\
(0.11)\end{array}$ & $\begin{array}{l}-0.19 \\
(0.51)\end{array}$ & $\begin{array}{l}-0.59^{* *} \\
(0.01)\end{array}$ \\
\hline \multicolumn{2}{|c|}{ ShareRight $\times$ kDeficit $\left(\alpha_{2}^{\prime}\right)$} & $\begin{array}{l}0.06 \\
(0.41)\end{array}$ & $\begin{array}{l}0.08 \\
(0.11)\end{array}$ & $\begin{array}{l}0.01 \\
(0.79)\end{array}$ & $\begin{array}{l}-0.00 \\
(0.98)\end{array}$ & $\begin{array}{l}-0.10 \\
(0.92)\end{array}$ & $\begin{array}{l}0.17 \\
(0.17)\end{array}$ & $\begin{array}{l}-0.05 \\
(0.93)\end{array}$ & $\begin{array}{l}-0.27 \\
(0.34)\end{array}$ & $\begin{array}{l}-0.08 \\
(0.21)\end{array}$ & $\begin{array}{l}-0.03 \\
(0.43)\end{array}$ \\
\hline \multicolumn{2}{|c|}{ ExcessCR $\times$ kDeficit $\left(\beta_{1}^{\prime}\right)$} & $\begin{array}{l}-0.14^{* *} \\
(0.02)\end{array}$ & $\begin{array}{l}-0.06^{* *} \\
(0.03)\end{array}$ & $\begin{array}{l}0.04^{*} \\
(0.05)\end{array}$ & $\begin{array}{l}0.02^{*} \\
(0.06)\end{array}$ & $\begin{array}{l}-0.49^{* *} \\
(0.03)\end{array}$ & $\begin{array}{l}-0.85^{* *} \\
(0.01)\end{array}$ & $\begin{array}{l}-0.48^{*} \\
(0.07)\end{array}$ & $\begin{array}{l}-0.61^{* *} \\
(0.02)\end{array}$ & $\begin{array}{l}-0.47^{*} \\
(0.06)\end{array}$ & $\begin{array}{l}-0.08 \\
(0.36)\end{array}$ \\
\hline \multicolumn{2}{|c|}{ ExcessCR $\times$ ShareRight $\times$ kDeficit $\left(\beta_{2}^{\prime}\right)$} & $\begin{array}{l}-0.00 \\
(0.95)\end{array}$ & $\begin{array}{l}-0.00 \\
(1.00)\end{array}$ & $\begin{array}{l}-0.04 \\
(0.60)\end{array}$ & $\begin{array}{l}-0.03 \\
(0.54)\end{array}$ & $\begin{array}{l}0.34 \\
(0.51)\end{array}$ & $\begin{array}{l}0.27 \\
(0.38)\end{array}$ & $\begin{array}{l}0.47^{*} \\
(0.07)\end{array}$ & $\begin{array}{l}0.58^{*} \\
(0.07)\end{array}$ & $\begin{array}{l}0.43 \\
(0.46)\end{array}$ & $\begin{array}{l}0.13 \\
(0.48)\end{array}$ \\
\hline \multicolumn{2}{|c|}{ Control variables } & Yes & Yes & Yes & Yes & Yes & Yes & Yes & Yes & Yes & Yes \\
\hline \multicolumn{2}{|c|}{ Number of observations } & 2,204 & 2,204 & 2,204 & 2,204 & 2,204 & 2,204 & 2,204 & 2,204 & 2,204 & 2,204 \\
\hline \multicolumn{2}{|c|}{ Number of banks } & 341 & 341 & 341 & 341 & 341 & 341 & 341 & 341 & 341 & 341 \\
\hline Hansen test: & $\begin{array}{l}\text { Statistic } \\
\text { P-value }\end{array}$ & $\begin{array}{l}286.92 \\
(0.31)\end{array}$ & $\begin{array}{l}297.53 \\
(0.18)\end{array}$ & $\begin{array}{l}299.88 \\
(0.15)\end{array}$ & $\begin{array}{l}292.30 \\
(0.24)\end{array}$ & $\begin{array}{l}285.67 \\
(0.33)\end{array}$ & $\begin{array}{l}274.06 \\
(0.52)\end{array}$ & $\begin{array}{l}291.92 \\
(0.24)\end{array}$ & $\begin{array}{l}295.23 \\
(0.20)\end{array}$ & $\begin{array}{l}285.48 \\
(0.33)\end{array}$ & $\begin{array}{l}279.29 \\
(0.43)\end{array}$ \\
\hline AR2 test: & $\begin{array}{l}\text { Statistic } \\
\text { P-value }\end{array}$ & $\begin{array}{l}0.12 \\
(0.90)\end{array}$ & $\begin{array}{l}0.02 \\
(0.98)\end{array}$ & $\begin{array}{l}-0.15 \\
(0.88)\end{array}$ & $\begin{array}{l}0.06 \\
(0.95)\end{array}$ & $\begin{array}{l}1.14 \\
(0.25)\end{array}$ & $\begin{array}{l}1.24 \\
(0.21)\end{array}$ & $\begin{array}{l}0.69 \\
(0.49)\end{array}$ & $\begin{array}{l}0.57 \\
(0.57)\end{array}$ & $\begin{array}{l}1.25 \\
(0.15)\end{array}$ & $\begin{array}{l}1.28 \\
(0.15)\end{array}$ \\
\hline \multicolumn{2}{|c|}{ Fitted target (\%): Mean } & 7.02 & 11.53 & 7.02 & 11.53 & 7.02 & 11.53 & 7.02 & 11.53 & 7.02 & 11.53 \\
\hline & Maximum & 14.92 & 24.87 & 14.92 & 24.87 & 14.92 & 24.87 & 14.92 & 24.87 & 14.92 & 24.87 \\
\hline \multicolumn{2}{|r|}{ Minimum } & 1.70 & 4.08 & 1.70 & 4.08 & 1.70 & 4.08 & 1.70 & 4.08 & 1.70 & 4.08 \\
\hline \multicolumn{2}{|c|}{$\begin{array}{l}\alpha_{1}+\alpha_{2} \\
\text { Wald test (P-value) }\end{array}$} & $\begin{array}{l}-0.06^{* *} \\
(0.04)\end{array}$ & $\begin{array}{l}-0.04^{*} \\
(0.10)\end{array}$ & $\begin{array}{l}-0.08^{* *} \\
(0.01)\end{array}$ & $\begin{array}{l}-0.05^{* *} \\
(0.03)\end{array}$ & $\begin{array}{l}0.87^{* * *} \\
(0.00)\end{array}$ & $\begin{array}{l}0.97^{* * *} \\
(0.00)\end{array}$ & $\begin{array}{l}0.48^{* *} \\
(0.03)\end{array}$ & $\begin{array}{l}0.57^{* *} \\
(0.02)\end{array}$ & $\begin{array}{l}0.55^{* *} \\
(0.03)\end{array}$ & $\begin{array}{l}0.80^{* * *} \\
(0.01)\end{array}$ \\
\hline \multicolumn{2}{|l|}{$\alpha_{1}+\beta_{1}$} & $\begin{array}{l}-0.16^{* *} \\
(0.05)\end{array}$ & $\begin{array}{l}-0.09^{* *} \\
(0.04)\end{array}$ & $\begin{array}{l}-0.01 \\
(0.81)\end{array}$ & $\begin{array}{l}-0.02 \\
(0.25)\end{array}$ & $\begin{array}{l}0.36 \\
(0.43)\end{array}$ & $\begin{array}{l}0.41 \\
(0.41)\end{array}$ & $\begin{array}{l}0.29 \\
(0.43)\end{array}$ & $\begin{array}{l}0.26 \\
(0.55)\end{array}$ & $\begin{array}{l}0.21 \\
(0.39)\end{array}$ & $\begin{array}{l}0.33 \\
(0.13)\end{array}$ \\
\hline \multirow{2}{*}{\multicolumn{2}{|c|}{$\begin{array}{l}\alpha_{1}+\beta_{1}+\alpha_{2}+\beta_{2} \\
\text { Wald test (P-value) }\end{array}$}} & $-0.08^{* *}$ & $-0.04^{* *}$ & $-0.06^{* *}$ & $-0.07^{* *}$ & $0.44^{*}$ & $0.47^{*}$ & 0.26 & 0.33 & 0.20 & 0.35 \\
\hline & & $(0.03)$ & $(0.04)$ & $(0.02)$ & $(0.02)$ & $(0.05)$ & $(0.08)$ & $(0.56)$ & $(0.19)$ & $(0.42)$ & $(0.20)$ \\
\hline$\alpha_{1}^{\prime}+\alpha_{2}^{\prime}$ & Wald test (P-value) & $\begin{array}{l}0.22^{* * *} \\
(0.00)\end{array}$ & $\begin{array}{l}0.15^{* * *} \\
(0.00)\end{array}$ & $\begin{array}{l}0.05 \\
(0.20)\end{array}$ & $\begin{array}{l}0.04 \\
(0.12)\end{array}$ & $\begin{array}{l}-0.45 \\
(0.14)\end{array}$ & $\begin{array}{l}0.08 \\
(64)\end{array}$ & $\begin{array}{l}-0.42 \\
(0.13)\end{array}$ & $\begin{array}{l}-0.56 \\
(0.11)\end{array}$ & $\begin{array}{l}-0.27 \\
(0.37)\end{array}$ & $\begin{array}{l}-0.62^{* * *} \\
(0.01)\end{array}$ \\
\hline$\alpha_{1}^{\prime}+\beta_{1}^{\prime}$ & & 0.02 & 0.01 & $0.08^{* * *}$ & $0.06^{* * *}$ & $-0.84^{* *}$ & $-0.94^{* *}$ & $-0.90^{* *}$ & $-0.90^{* *}$ & $-0.66^{* *}$ & $-0.67^{* *}$ \\
\hline Wald test $\left(\mathrm{P}_{-}\right.$ & & $(0.64)$ & $(0.73)$ & $(0.02)$ & $(0.02)$ & $(0.01)$ & $(0.03)$ & $(0.05)$ & $(0.01)$ & $(0.02)$ & $(0.02)$ \\
\hline$\alpha_{1}^{\prime}+\beta_{1}^{\prime}+c$ & $+\beta_{2}^{\prime}$ & $0.08^{* *}$ & $0.09^{* * * *}$ & $0.05^{*}$ & 0.03 & $-0.60^{*}$ & $-0.50^{*}$ & -0.43 & -0.59 & -0.31 & $-0.57^{*}$ \\
\hline Wald test $(\mathrm{P}-$ & ue) & $(0.04)$ & $(0.00)$ & $(0.06)$ & $(0.14)$ & $(0.07)$ & $(0.10)$ & $(0.21)$ & $(0.11)$ & $(0.14)$ & $(0.08)$ \\
\hline
\end{tabular}

Variables definition: $\Delta$ Tier1=annual change in Tier 1 capital less current retained earnings/average assets; RetainedEarnings=current net income less current dividend payment/average assets; $\Delta$ Assets=annual change in total assets/average assets; $\Delta$ Loans=annual change in net loans/average assets; $\triangle \mathrm{RWA}=$ annual change in risk-weighted assets/average assets; average assets $=\left(\right.$ total assets $_{\mathrm{t}}+$ total assets $\left.\mathrm{t}_{\mathrm{t}-1}\right) / 2$; Tier1TA and Tier1RWA are respectively nonrisk- and risk-based target Tier 1 capital ratios; kSurplus=absolute value of the gap between the target and the lagged Tier 1 ratios when the bank is above its target, and zero otherwise; ShareRight=dummy equal to one if the shareholder protection index is greater than the median value, and zero otherwise; ExcessCR=dummy equal to one if control rights are greater than cash-flow rights, and zero otherwise; kDeficit=absolute value of the gap between the target and the lagged Tier 1 ratios when the bank is below its target, and zero otherwise. The regressions contain the same control variables as in Table 4 (see their definition in Table A5 in Appendix A). Country and Year dummies are included but not reported. Detailed results are available on request. Hansen test=test of exogeneity of all instruments as a group; AR2 test=second order residual autocorrelation test. P-values based on robust standard errors are shown in parentheses. ${ }^{*},{ }^{* *}$ and ${ }^{* * *}$ indicate statistical significance at the $10 \%, 5 \%$ and $1 \%$ levels respectively. 
Table 7: Excess control rights and capital ratio adjustment: 2008 financial crisis (2002-2010, GMM)

$$
\begin{gathered}
\mathrm{y}_{\mathrm{i}, \mathrm{t}}=\left[\alpha_{1}+\alpha_{2} \text { Crisis }+\left(\beta_{1}+\beta_{2} \text { Crisis }\right) \text { ExcessCR }\right] \mathrm{kSurplus}_{\mathrm{i}, \mathrm{t}-1}+\left[\alpha^{\prime}{ }_{1}+\alpha^{\prime}{ }_{2} \text { Crisis }+\left(\beta^{\prime}{ }_{1}+\beta^{\prime}{ }_{2} \text { Crisis }\right)\right. \\
\text { ExcessCR }] \mathrm{kDeficit}_{\mathrm{i}, \mathrm{t}-1}+\theta \mathrm{y}_{\mathrm{i}, \mathrm{t}-1}+\delta^{\prime} \mathrm{z}_{\mathrm{i}, \mathrm{t}-1}+\gamma^{\prime} \mathrm{V}_{\mathrm{c}, \mathrm{t}-1}+\alpha_{0}+\omega^{\prime} \text { Country }+\tau^{\prime} \text { Year }+\varepsilon_{\mathrm{i}, \mathrm{t}}
\end{gathered}
$$

\begin{tabular}{|c|c|c|c|c|c|c|c|c|c|c|c|}
\hline \multirow{3}{*}{\multicolumn{2}{|c|}{$\begin{array}{l}\text { Dependent variable y } \\
(1)=\text { Tier1TA, }(2)=\text { Tier1RWA }\end{array}$}} & \multicolumn{4}{|c|}{ Capital adjustment } & \multicolumn{6}{|c|}{ Assets adjustment } \\
\hline & & \multicolumn{2}{|c|}{$\Delta$ Tier1 } & \multicolumn{2}{|c|}{ RetainedEarnings } & \multicolumn{2}{|c|}{$\Delta$ Assets } & \multicolumn{2}{|c|}{$\Delta$ Loans } & \multicolumn{2}{|c|}{$\Delta \mathrm{RWA}$} \\
\hline & & $(1)$ & $(2)$ & $(1)$ & $(2)$ & $(1)$ & $(2)$ & $(1)$ & $(2)$ & $(1)$ & $(2)$ \\
\hline \multirow{2}{*}{\multicolumn{2}{|c|}{ kSurplus $\left(\alpha_{1}\right)$}} & $-0.09^{* * * *}$ & $-0.06^{* * *}$ & $-0.04^{* *}$ & $-0.05^{* *}$ & $1.08^{* * *}$ & $1.15^{* * *}$ & $0.53^{* *}$ & $0.63^{* *}$ & $0.61^{* *}$ & $0.91^{* *}$ \\
\hline & & $(0.01)$ & $(0.02)$ & $(0.03)$ & $(0.03)$ & $(0.02)$ & $(0.00)$ & $(0.03)$ & $(0.02)$ & $(0.02)$ & $(0.01)$ \\
\hline \multirow{2}{*}{\multicolumn{2}{|c|}{ Crisis $\times$ kSurplus $\left(\alpha_{2}\right)$}} & $0.05^{*}$ & 0.03 & -0.02 & -0.01 & -0.62 & -0.45 & -0.20 & -0.28 & -0.30 & -0.40 \\
\hline & & $(0.07)$ & $(0.49)$ & $(0.13)$ & $(0.12)$ & $(0.75)$ & $(0.67)$ & $(0.71)$ & $(0.59)$ & $(0.12)$ & $(0.27)$ \\
\hline \multirow{2}{*}{\multicolumn{2}{|c|}{ ExcessCR $\times$ kSurplus $\left(\beta_{1}\right)$}} & -0.04 & -0.03 & 0.01 & 0.03 & -0.62 & -0.65 & -0.17 & -0.29 & -0.32 & -0.54 \\
\hline & & $(0.51)$ & $(0.50)$ & $(0.61)$ & $(0.16)$ & $(0.77)$ & $(0.47)$ & $(0.50)$ & $(0.80)$ & $(0.42)$ & $(0.45)$ \\
\hline \multirow{2}{*}{\multicolumn{2}{|c|}{ ExcessCR $\times$ Crisis $\times$ kSurplus $\left(\beta_{2}\right)$}} & 0.04 & 0.03 & -0.02 & -0.03 & 0.50 & 0.35 & 0.06 & 0.16 & 0.22 & 0.37 \\
\hline & & $(0.63)$ & $(0.25)$ & $(0.92)$ & $(0.65)$ & $(0.23)$ & $(0.41)$ & $(0.88)$ & $(0.70)$ & $(0.80)$ & $(0.28)$ \\
\hline \multirow{2}{*}{\multicolumn{2}{|c|}{ kDeficit $\left(\alpha_{1}^{\prime}\right)$}} & $0.16^{* *}$ & $0.12^{* * *}$ & 0.04 & 0.06 & -0.43 & 0.07 & -0.24 & -0.32 & -0.25 & $-0.65^{* *}$ \\
\hline & & $(0.04)$ & $(0.01)$ & $(0.17)$ & $(0.10)$ & $(0.28)$ & $(0.85)$ & $(0.73)$ & $(0.35)$ & $(0.12)$ & $(0.02)$ \\
\hline \multirow{2}{*}{\multicolumn{2}{|c|}{ Crisis $\times$ kDeficit $\left(\alpha_{2}^{\prime}\right)$}} & -0.06 & -0.06 & -0.01 & -0.02 & -0.06 & 0.18 & -0.21 & -0.14 & -0.18 & 0.18 \\
\hline & & $(0.39)$ & $(0.85)$ & $(0.21)$ & $(0.19)$ & $(0.51)$ & $(0.66)$ & $(0.75)$ & $(0.59)$ & $(0.22)$ & $(0.80)$ \\
\hline \multirow{2}{*}{\multicolumn{2}{|c|}{ ExcessCR $\times$ kDeficit $\left(\beta^{\prime}{ }_{1}\right)$}} & $-0.12^{*}$ & $-0.10^{*}$ & 0.06 & $0.06^{*}$ & $-0.50^{*}$ & $-0.96^{* *}$ & $-0.42^{*}$ & $-0.51^{*}$ & $-0.48^{* *}$ & -0.15 \\
\hline & & $(0.07)$ & $(0.08)$ & $(0.16)$ & $(0.06)$ & $(0.08)$ & $(0.01)$ & $(0.05)$ & $(0.06)$ & $(0.04)$ & $(0.82)$ \\
\hline \multirow{2}{*}{\multicolumn{2}{|c|}{ ExcessCR $\times$ Crisis $\times$ kDeficit $\left(\beta_{2}^{\prime}\right)$}} & 0.10 & 0.10 & -0.04 & -0.05 & 0.47 & 0.20 & 0.43 & 0.51 & 0.62 & 0.33 \\
\hline & & $(0.24)$ & $(0.17)$ & $(0.43)$ & $(0.73)$ & $(0.15)$ & $(0.44)$ & $(0.24)$ & $(0.38)$ & $(0.12)$ & $(0.29)$ \\
\hline \multicolumn{2}{|c|}{ Control variables } & Yes & Yes & Yes & Yes & Yes & Yes & Yes & Yes & Yes & Yes \\
\hline \multicolumn{2}{|c|}{ Number of observations } & 2,204 & 2,204 & 2,204 & 2,204 & 2,204 & 2,204 & 2,204 & 2,204 & 2,204 & 2,204 \\
\hline \multicolumn{2}{|c|}{ Number of banks } & 341 & 341 & 341 & 341 & 341 & 341 & 341 & 341 & 341 & 341 \\
\hline \multirow[t]{2}{*}{ Hansen test: } & Statistic & 196.48 & 188.16 & 193.55 & 204.38 & 179.66 & 182.09 & 185.55 & 214.86 & 186.52 & 184.56 \\
\hline & P-value & $(0.17)$ & $(0.14)$ & $(0.09)$ & $(0.13)$ & $(0.26)$ & $(0.22)$ & $(0.17)$ & $(0.11)$ & $(0.16)$ & $(0.18)$ \\
\hline \multirow[t]{2}{*}{ AR2 test: } & Statistic & 0.13 & 0.11 & -0.12 & 0.10 & 1.26 & 1.23 & 0.72 & 0.51 & 1.08 & 1.06 \\
\hline & P-value & $(0.90)$ & $(0.89)$ & $(0.90)$ & $(0.80)$ & $(0.21)$ & $(0.22)$ & $(0.47)$ & $(0.61)$ & $(0.34)$ & $(0.35)$ \\
\hline \multicolumn{2}{|c|}{ Fitted target (\%):Mean } & 7.02 & 11.53 & 7.02 & 11.53 & 7.02 & 11.53 & 7.02 & 11.53 & 7.02 & 11.53 \\
\hline & Maximum & 14.92 & 24.87 & 14.92 & 24.87 & 14.92 & 24.87 & 14.92 & 24.87 & 14.92 & 24.87 \\
\hline \multirow{3}{*}{\multicolumn{2}{|c|}{ Minimum }} & 1.70 & 4.08 & 1.70 & 4.08 & 1.70 & 4.08 & 1.70 & 4.08 & 1.70 & 4.08 \\
\hline & & $-0.04^{*}$ & -0.03 & $-0.06^{* * *}$ & $-0.06^{* *}$ & $0.46^{*}$ & $0.70^{* *}$ & 0.33 & 0.35 & 0.31 & $0.51^{* *}$ \\
\hline & & $(0.10)$ & $(0.11)$ & $(0.02)$ & $(0.01)$ & $(0.09)$ & $(0.04)$ & $(0.55)$ & $(0.57)$ & $(0.45)$ & $(0.05)$ \\
\hline$\alpha_{1}+\beta_{1}$ & & $-0.13^{* *}$ & $-0.09^{* *}$ & -0.03 & -0.02 & 0.46 & 0.50 & 0.36 & 0.34 & 0.29 & 0.37 \\
\hline Wald test $(\mathrm{P}$ & lue) & $(0.01)$ & $(0.02)$ & $(0.60)$ & $(0.14)$ & $(0.13)$ & $(0.43)$ & $(0.50)$ & $(0.66)$ & $(0.54)$ & $(0.32)$ \\
\hline$\alpha_{1}+\beta_{1}+\alpha_{2}$ & & -0.04 & $-0.03^{*}$ & $-0.07^{* *}$ & $-0.06^{* *}$ & 0.34 & 0.40 & 0.22 & 0.22 & 0.21 & 0.34 \\
\hline Wald test $(\mathrm{P}$ & lue) & $(0.16)$ & (0.09) & $(0.03)$ & $(0.01)$ & $(0.73)$ & $(0.69)$ & $(0.72)$ & $(0.71)$ & $(0.62)$ & $(0.73)$ \\
\hline$\alpha_{1}^{\prime}+\alpha_{2}^{\prime}$ & & $0.10^{* *}$ & $0.06^{* *}$ & 0.03 & 0.04 & -0.49 & 0.25 & -0.45 & -0.46 & -0.43 & $-0.47^{*}$ \\
\hline Wald test $(\mathrm{P}$ & lue) & $(0.04)$ & $(0.04)$ & $(0.20)$ & $(0.12)$ & $(0.25)$ & $(0.51)$ & $(0.31)$ & $(0.29)$ & $(0.47)$ & $(0.08)$ \\
\hline$\alpha_{1}^{\prime}+\beta_{1}^{\prime}$ & & 0.04 & 0.02 & $0.10^{* * * *}$ & $0.12^{* * *}$ & $-0.93^{* *}$ & $-0.89^{* * *}$ & $-0.66^{* *}$ & $-0.83^{* *}$ & $-0.73^{* * *}$ & $-0.80^{* *}$ \\
\hline Wald test $(\mathrm{P}$ & lue) & $(0.21)$ & $(0.32)$ & $(0.00)$ & $(0.01)$ & $(0.03)$ & $(0.01)$ & $(0.02)$ & $(0.01)$ & $(0.01)$ & $(0.01)$ \\
\hline$\alpha_{1}^{\prime}+\beta_{1}^{\prime}+c$ & $+\beta_{2}^{\prime}$ & $0.08^{* *}$ & $0.06^{* * *}$ & 0.05 & 0.05 & -0.52 & -0.51 & -0.44 & -0.46 & -0.29 & -0.29 \\
\hline Wald test $(\mathrm{P}$ & lue) & $(0.04)$ & $(0.05)$ & $(0.36)$ & $(0.53)$ & $(0.23)$ & $(0.40)$ & $(0.16)$ & $(0.47)$ & $(0.15)$ & $(0.20)$ \\
\hline
\end{tabular}

Variables definition: $\Delta$ Tier1=annual change in Tier 1 capital less current retained earnings/average assets; RetainedEarnings=current net income less current dividend payment/average assets; $\Delta$ Assets=annual change in total assets/average assets; $\Delta$ Loans $=$ annual change in net loans/average assets; $\triangle \mathrm{RWA}=$ annual change in risk-weighted assets/average assets; average assets $=\left(\right.$ total assets $_{\mathrm{t}}+$ total assets $\left.\mathrm{t}_{-1}\right) / 2$; Tier1TA and Tier1RWA are respectively nonrisk- and risk-based target Tier 1 capital ratios; kSurplus=absolute value of the gap between the target and the lagged Tier 1 ratios when the bank is above its target, and zero otherwise; Crisis=dummy equal to one if the observation is from 2008 or 2009, and zero otherwise; ExcessCR=dummy equal to one if control rights are greater than cash-flow rights, and zero otherwise; kDeficit=absolute value of the gap between the target and the lagged Tier 1 ratios when the bank is below its target, and zero otherwise. The regressions contain the same control variables as in Table 4 (see their definition in Table A5 in Appendix A). Country and Year dummies are included but not reported. Detailed results are available on request. Hansen test=test of exogeneity of all instruments as a group; AR2 test=second order residual autocorrelation test. P-values based on robust standard errors are shown in parentheses. ${ }^{*},{ }^{* *}$ and ${ }^{* * * *}$ indicate statistical significance at the $10 \%, 5 \%$ and $1 \%$ levels respectively. 
Table 8. Excess control rights and capital ratio adjustment: a summary of results

\begin{tabular}{|c|c|c|c|c|c|c|c|c|c|c|}
\hline & \multicolumn{5}{|c|}{ When banks are above the target capital ratio } & \multicolumn{5}{|c|}{ When banks are below the target capital ratio } \\
\hline & \multicolumn{2}{|c|}{ Capital adjustment } & \multicolumn{3}{|c|}{ Assets adjustment } & \multicolumn{2}{|c|}{ Capital adjustment } & \multicolumn{3}{|c|}{ Assets adjustment } \\
\hline & Equity & $\begin{array}{l}\text { Retained } \\
\text { earnings }\end{array}$ & Assets & Loans & RWA & Equity & $\begin{array}{l}\text { Retained } \\
\text { earnings }\end{array}$ & Assets & Loans & RWA \\
\hline \multirow{3}{*}{$\begin{array}{l}\text { In absence of } \\
\text { excess control } \\
\text { rights }\end{array}$} & $\downarrow$ & $\downarrow$ & $\uparrow$ & $\uparrow$ & $\uparrow$ & $\uparrow$ & $\rightarrow$ & $\rightarrow$ & $\rightarrow$ & $\downarrow$ \\
\hline & \multicolumn{5}{|c|}{$\begin{array}{l}\text { Effects are similar across (i) ownership type and (ii) level of shareholder } \\
\text { protection and hold during normal times } \\
\text { Effects during distress times: }\end{array}$} & \multirow{2}{*}{\multicolumn{5}{|c|}{$\begin{array}{l}\text { Effects are steady across (i) ownership type; (ii) level of shareholder of } \\
\text { protection; and (iii) normal and distress times }\end{array}$}} \\
\hline & $\rightarrow$ & $\downarrow$ & $\uparrow$ & $\rightarrow$ & $\uparrow$ & & & & & \\
\hline \multirow{3}{*}{$\begin{array}{l}\text { In presence of } \\
\text { excess control } \\
\text { rights }\end{array}$} & $\downarrow$ & $\rightarrow$ & $\rightarrow$ & $\rightarrow$ & $\rightarrow$ & $\rightarrow$ & $\uparrow$ & $\downarrow$ & $\downarrow$ & $\downarrow$ \\
\hline & \multicolumn{5}{|c|}{$\begin{array}{l}\text { Effects are similar across (i) ownership type and (ii) level of shareholder of } \\
\text { protection and hold during normal times. } \\
\text { Effects during distress times: }\end{array}$} & \multicolumn{5}{|c|}{$\begin{array}{l}\text { Effects only hold for: (i) family-controlled banks; (ii) countries with relatively } \\
\text { weak shareholder protection; (iii) normal times } \\
\text { Otherwise, the effects are like in the absence of excess control rights: }\end{array}$} \\
\hline & $\rightarrow$ & $\downarrow$ & $\rightarrow$ & $\rightarrow$ & $\rightarrow$ & $\uparrow$ & $\rightarrow$ & $\rightarrow$ & $\rightarrow$ & $\downarrow$ \\
\hline
\end{tabular}

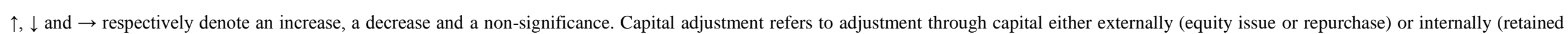
earnings). Assets adjustment include adjustments through total assets (Assets), customer loans (Loans) and risk-weighted assets (RWA). 


\section{APPENDIX A}

Table A1. Distribution of European commercial banks and representativeness of the final sample

\begin{tabular}{llll}
\hline Country & All Banks & Listed Banks & Percent of total assets \\
\hline Austria & 9 & 2 & 39.19 \\
Belgium & 8 & 0 & 97.56 \\
Denmark & 43 & 33 & 93.75 \\
Finland & 2 & 0 & 85.79 \\
France & 18 & 6 & 74.74 \\
Germany & 22 & 7 & 74.52 \\
Greece & 10 & 9 & 94.84 \\
Ireland & 11 & 5 & 94.14 \\
Italy & 99 & 18 & 81.49 \\
Luxembourg & 14 & 3 & 50.06 \\
Netherlands & 17 & 4 & 61.04 \\
Norway & 7 & 3 & 73.53 \\
Portugal & 9 & 2 & 81.39 \\
Spain & 16 & 9 & 87.24 \\
Sweden & 9 & 2 & 83.02 \\
Switzerland & 12 & 3 & 87.17 \\
United Kingdom & 35 & 5 & 71.44 \\
Total/Mean & $\mathbf{3 4 1}$ & $\mathbf{1 1 1}$ & $\mathbf{7 8 . 2 8}$ \\
\hline
\end{tabular}

Percent of total assets=percentage of total assets of our sample banks in a given country in the aggregate total assets of all commercial banks provided by Bankscope in the same country over the 2002-2010 period.

Table A2. General descriptive statistics of the final sample (341 banks), on average, over the 20022010 period

\begin{tabular}{llllllllll}
\hline & Assets & Deposits & Loans & LoanlossProv & TotalCapital & Tier1TA & Tier1RWA & ROA & ROE \\
\hline Mean & 84,248 & 47.79 & 60.78 & 0.72 & 13.47 & 7.20 & 11.35 & 0.59 & 7.62 \\
Median & 5,926 & 48.45 & 63.87 & 0.47 & 12.20 & 6.07 & 9.72 & 0.54 & 8.64 \\
Standard deviation & 231,000 & 22.70 & 21.06 & 1.00 & 4.78 & 4.14 & 5.27 & 0.86 & 11.28 \\
Minimum & 57 & 3.88 & 10.03 & -0.74 & 8.05 & 1.44 & 4.90 & -2.98 & -48.96 \\
Maximum & $2,202,423$ & 91.96 & 95.96 & 5.65 & 33.78 & 21.83 & 31.70 & 3.32 & 31.44 \\
\hline
\end{tabular}

Variables definition: All variables are expressed in percentages except Assets which is in millions of Euros. Assets=bank's total assets; Deposits=ratio of total customer deposits to total assets; Loans=ratio of net loans to total assets; LoanlossProv=ratio of loan loss provisions to net loans; TotalCapital=risk-based total capital ratio; Tier1TA=nonrisk-based Tier 1 capital ratio; Tier1RWA=riskbased Tier 1 capital ratio; ROA=return on assets; ROE=return on equity. 
Table A3. Description of the control variables used to estimate the target capital ratio and their descriptive statistics, on average, over the period 2002-2010.

\begin{tabular}{|c|c|c|c|c|c|c|c|c|}
\hline Variable & Description & $\begin{array}{l}\text { Expected } \\
\text { sign }\end{array}$ & Authors & Mean $^{*}$ & $\begin{array}{l}\text { Standard } \\
\text { deviation }\end{array}$ & Minimum & Maximum & $\begin{array}{l}\text { Number of } \\
\text { Observations }\end{array}$ \\
\hline ExcessCR & $\begin{array}{l}\text { Dummy variable equal to one if } \\
\text { voting rights are greater than cash- } \\
\text { flow rights, and zero otherwise }\end{array}$ & $(-)$ & $\begin{array}{l}\text { Brewer III, Kaufman, and } \\
\text { Wall (2008) }\end{array}$ & 0.36 & 0.48 & 0 & 1 & 2,204 \\
\hline Log(Assets) & $\begin{array}{l}\text { Bank size measured by the natural } \\
\text { logarithm of total assets (Millions of } \\
\text { Euros) }\end{array}$ & $(-)$ & $\begin{array}{l}\text { Nier and Baumann (2006); } \\
\text { Brewer III, Kaufman, and } \\
\text { Wall (2008); Flannery and } \\
\text { Rangan (2008) }\end{array}$ & 8.84 & 2.41 & 3.83 & 14.61 & 2,204 \\
\hline ROA & $\begin{array}{l}\text { Bank profitability measured by the } \\
\text { return on assets (\%) }\end{array}$ & $(+/-)$ & $\begin{array}{l}\text { Marcus (1983); Ayuso, Pérez, } \\
\text { and Saurina (2004); Flannery } \\
\text { and Rangan (2008) }\end{array}$ & 0.59 & 0.86 & -2.98 & 3.31 & 2,204 \\
\hline LoanlossProv & $\begin{array}{l}\text { Bank risk measured by the ratio of } \\
\text { loan loss provisions to net loans (\%) }\end{array}$ & $(+/-)$ & $\begin{array}{l}\text { Ayuso, Pérez, and Saurina } \\
\text { (2004); Nier and Baumann } \\
\text { (2006); Jokipii and Milne } \\
\text { (2008) }\end{array}$ & 0.72 & 1 & -0.74 & 5.65 & 2,204 \\
\hline Loans & $\begin{array}{l}\text { Bank business model measured by } \\
\text { the ratio of net loans to total assets } \\
(\%)\end{array}$ & $(-)$ & $\begin{array}{l}\text { Ayuso, Pérez, and Saurina } \\
\text { (2004) }\end{array}$ & 60.78 & 21.06 & 10.03 & 95.96 & 2,204 \\
\hline MarketDiscipline & $\begin{array}{l}\text { Market discipline measured by the } \\
\text { ratio of total long term market } \\
\text { funding to total funding }(\%)\end{array}$ & $(+)$ & Nier and Baumann (2006) & 24.16 & 24.98 & 0.08 & 84.07 & 2,204 \\
\hline Listed & $\begin{array}{l}\text { Dummy variable equal to one if the } \\
\text { bank is listed, and zero otherwise }\end{array}$ & $(-)$ & $\begin{array}{l}\text { Shehzad, de Haan, and } \\
\text { Scholtens (2010) }\end{array}$ & 0.39 & 0.49 & 0 & 1 & 2,204 \\
\hline GDPGrowth & $\begin{array}{l}\text { Business cycle measured by the real } \\
\text { GDP (Growth Domestic Product) } \\
\text { growth rate (\%) }\end{array}$ & $(+/-)$ & $\begin{array}{l}\text { Ayuso, Pérez, and Saurina } \\
\text { (2004); Nier and Baumann } \\
\text { (2006); Jokipii and Milne } \\
\text { (2008) }\end{array}$ & 1.28 & 2.73 & -8.20 & 6.64 & 2,204 \\
\hline
\end{tabular}


Table A4. Estimating the target capital ratio using a partial adjustment model for European commercial banks (2002-2010)

$\mathrm{k}_{\mathrm{i}, \mathrm{t}}=(1-\lambda) \mathrm{k}_{\mathrm{i}, \mathrm{t}-1}+\lambda\left(\varphi^{\prime} \mathrm{X}_{\mathrm{i}, \mathrm{t}-1}+\rho \mathrm{GDPGrowth}_{\mathrm{c}, \mathrm{t}-1}+\omega^{\prime}\right.$ Country $+\tau^{\prime}$ Year $\left.+\mu_{\mathrm{i}}\right)+\eta_{\mathrm{i}, \mathrm{t}}$

\begin{tabular}{|c|c|c|c|c|c|c|c|c|}
\hline & \multicolumn{4}{|c|}{ Full sample } & \multicolumn{4}{|c|}{ Subsamples } \\
\hline & & eline & $\begin{array}{r}\text { Excess c } \\
\text { differen }\end{array}$ & $\begin{array}{l}\text { ntrol rights } \\
\text { ated target }\end{array}$ & Baseline & $x \operatorname{xcess}$ Control $=0$ & Baseline & xcessControl $>0$ \\
\hline Dependent variable $\mathrm{k}$ & Tier1TA & Tier1RWA & Tier1TA & Tier1RWA & Tier1TA & Tier1RWA & Tier1TA & Tier1RWA \\
\hline Lagged value of $k\left(\mathrm{k}_{\mathrm{i}, \mathrm{t}-1)}\right.$ & $\begin{array}{l}0.59^{* * * *} \\
(0.00)\end{array}$ & $\begin{array}{l}0.66^{* * * *} \\
(0.00)\end{array}$ & $\begin{array}{l}0.60^{* * * *} \\
(0.00)\end{array}$ & $\begin{array}{l}0.66^{* * * *} \\
(0.00)\end{array}$ & $\begin{array}{l}0.57^{* * * *} \\
(0.00)\end{array}$ & $\begin{array}{l}0.67^{* * * *} \\
(0.00)\end{array}$ & $\begin{array}{l}0.56^{* * * *} \\
(0.00)\end{array}$ & $\begin{array}{l}0.35^{* * *} \\
(0.00)\end{array}$ \\
\hline ExcessCR & & & $\begin{array}{l}-0.33^{* *} \\
(0.04)\end{array}$ & $\begin{array}{l}-0.73^{\text {**** }} \\
(0.00)\end{array}$ & & & & \\
\hline Log(Assets) & $\begin{array}{l}-0.51^{* * * *} \\
(0.00)\end{array}$ & $\begin{array}{l}-0.56^{\text {**** }} \\
(0.00)\end{array}$ & $\begin{array}{l}-0.51^{* * * *} \\
(0.00)\end{array}$ & $\begin{array}{l}-0.57^{\text {*** }} \\
(0.00)\end{array}$ & $\begin{array}{l}-0.04 \\
(0.33)\end{array}$ & $\begin{array}{l}-0.04 \\
(0.58)\end{array}$ & $\begin{array}{l}-0.42^{* * * *} \\
(0.00)\end{array}$ & $\begin{array}{l}-0.41^{* * *} \\
(0.00)\end{array}$ \\
\hline ROA & $\begin{array}{l}0.48^{* * *} \\
(0.00)\end{array}$ & $\begin{array}{l}0.54^{* * * *} \\
(0.00)\end{array}$ & $\begin{array}{l}0.47^{* * * *} \\
(0.00)\end{array}$ & $\begin{array}{l}0.54^{* * *} \\
(0.00)\end{array}$ & $\begin{array}{l}0.59^{* * * *} \\
(0.00)\end{array}$ & $\begin{array}{l}0.69^{* * * *} \\
(0.00)\end{array}$ & $\begin{array}{l}0.27^{* * * *} \\
(0.00)\end{array}$ & $\begin{array}{l}0.45^{* * * *} \\
(0.00)\end{array}$ \\
\hline LoanlossProv & $\begin{array}{l}0.19^{* * *} \\
(0.00)\end{array}$ & $\begin{array}{l}0.16^{* *} \\
(0.04)\end{array}$ & $\begin{array}{l}0.19^{* * * *} \\
(0.00)\end{array}$ & $\begin{array}{l}0.16^{* *} \\
(0.04)\end{array}$ & $\begin{array}{l}0.27^{* * * * *} \\
(0.00)\end{array}$ & $\begin{array}{l}0.28^{* * * *} \\
(0.00)\end{array}$ & $\begin{array}{l}0.18^{* * *} \\
(0.00)\end{array}$ & $\begin{array}{l}-0.07 \\
(0.25)\end{array}$ \\
\hline Loans & $\begin{array}{l}-0.02^{* * *} \\
(0.00)\end{array}$ & $\begin{array}{l}-0.03^{* * *} \\
(0.00)\end{array}$ & $\begin{array}{l}-0.02^{* * *} \\
(0.00)\end{array}$ & $\begin{array}{l}-0.03^{* * *} \\
(0.00)\end{array}$ & $\begin{array}{l}-0.01^{* * *} \\
(0.00)\end{array}$ & $\begin{array}{l}-0.02^{* * *} \\
(0.00)\end{array}$ & $\begin{array}{l}-0.00 \\
(0.20)\end{array}$ & $\begin{array}{l}-0.03^{* * * *} \\
(0.00)\end{array}$ \\
\hline MarketDiscipline & $\begin{array}{l}0.00^{* *} \\
(0.02)\end{array}$ & $\begin{array}{l}0.01^{* *} \\
(0.01)\end{array}$ & $\begin{array}{l}0.00^{* *} \\
(0.02)\end{array}$ & $\begin{array}{l}0.01^{* *} \\
(0.02)\end{array}$ & $\begin{array}{l}0.01^{* * * *} \\
(0.00)\end{array}$ & $\begin{array}{l}0.01^{* * *} \\
(0.00)\end{array}$ & $\begin{array}{l}0.01^{\text {**** }} \\
(0.00)\end{array}$ & $\begin{array}{l}0.00 \\
(0.27)\end{array}$ \\
\hline Listed & $\begin{array}{l}-0.70^{* * *} \\
(0.00)\end{array}$ & $\begin{array}{l}-1.45^{* * * *} \\
(0.00)\end{array}$ & $\begin{array}{l}-0.67^{* * *} \\
(0.00)\end{array}$ & $\begin{array}{l}-1.41^{\text {**** }} \\
(0.00)\end{array}$ & $\begin{array}{l}-0.22^{*} \\
(0.06)\end{array}$ & $\begin{array}{l}-0.09 \\
(0.61)\end{array}$ & $\begin{array}{l}-0.44^{* * *} \\
(0.00)\end{array}$ & $\begin{array}{l}-0.51^{\text {**** }} \\
(0.00)\end{array}$ \\
\hline GDPGrowth & $\begin{array}{l}-0.00 \\
(0.64)\end{array}$ & $\begin{array}{l}-0.01 \\
(0.29)\end{array}$ & $\begin{array}{l}-0.00 \\
(0.61)\end{array}$ & $\begin{array}{l}-0.01 \\
(0.28)\end{array}$ & $\begin{array}{l}-0.03^{* *} \\
(0.05)\end{array}$ & $\begin{array}{l}-0.05^{* *} \\
(0.01)\end{array}$ & $\begin{array}{l}0.03^{* * *} \\
(0.00)\end{array}$ & $\begin{array}{l}0.02^{* *} \\
(0.04)\end{array}$ \\
\hline Intercept & $\begin{array}{l}5.12^{* * * *} \\
(0.00) \\
\end{array}$ & $\begin{array}{l}7.77^{* * *} \\
(0.00) \\
\end{array}$ & $\begin{array}{l}5.14^{* * * *} \\
(0.00) \\
\end{array}$ & $\begin{array}{l}7.84^{* * *} \\
(0.00) \\
\end{array}$ & $\begin{array}{l}5.93^{* *} \\
(0.03) \\
\end{array}$ & $\begin{array}{l}6.95^{* * *} \\
(0.00)\end{array}$ & $\begin{array}{l}5.94^{* * *} \\
(0.00) \\
\end{array}$ & $\begin{array}{l}10.20^{* * * *} \\
(0.00) \\
\end{array}$ \\
\hline $\begin{array}{l}\text { Country dummies } \\
\text { Year dummies }\end{array}$ & $\begin{array}{l}\text { Yes } \\
\text { Yes }\end{array}$ & $\begin{array}{l}\text { Yes } \\
\text { Yes }\end{array}$ & $\begin{array}{l}\text { Yes } \\
\text { Yes }\end{array}$ & $\begin{array}{l}\text { Yes } \\
\text { Yes }\end{array}$ & $\begin{array}{l}\text { Yes } \\
\text { Yes }\end{array}$ & $\begin{array}{l}\text { Yes } \\
\text { Yes }\end{array}$ & $\begin{array}{l}\text { Yes } \\
\text { Yes }\end{array}$ & $\begin{array}{l}\text { Yes } \\
\text { Yes }\end{array}$ \\
\hline $\begin{array}{l}\text { Number of observations } \\
\text { Number of banks }\end{array}$ & $\begin{array}{l}2,204 \\
341 \\
\end{array}$ & $\begin{array}{l}2,204 \\
341 \\
\end{array}$ & $\begin{array}{l}2,204 \\
341 \\
\end{array}$ & $\begin{array}{l}2,204 \\
341 \\
\end{array}$ & $\begin{array}{l}1,416 \\
236\end{array}$ & $\begin{array}{l}1,416 \\
236 \\
\end{array}$ & $\begin{array}{l}788 \\
154 \\
\end{array}$ & $\begin{array}{l}788 \\
154 \\
\end{array}$ \\
\hline $\begin{array}{r}\text { Hansen test: Statistic } \\
\text { P-value }\end{array}$ & $\begin{array}{l}135.59 \\
(0.11)\end{array}$ & $\begin{array}{l}117 \\
(0.10)\end{array}$ & $\begin{array}{l}135.24 \\
(0.11)\end{array}$ & $\begin{array}{l}117.38 \\
(0.10)\end{array}$ & $\begin{array}{l}132.61 \\
(0.11)\end{array}$ & $\begin{array}{l}131.18 \\
(0.12)\end{array}$ & $\begin{array}{l}115.20 \\
(0.13)\end{array}$ & $\begin{array}{l}112.92 \\
(0.16)\end{array}$ \\
\hline $\begin{array}{ll}\text { AR2 test: } & \text { Statistic } \\
& \text { P-value }\end{array}$ & $\begin{array}{l}0.93 \\
(0.35)\end{array}$ & $\begin{array}{l}-1.01 \\
(0.31)\end{array}$ & $\begin{array}{l}0.93 \\
(0.35)\end{array}$ & $\begin{array}{l}-0.99 \\
(0.32)\end{array}$ & $\begin{array}{l}0.34 \\
(0.73)\end{array}$ & $\begin{array}{l}-0.74 \\
(0.46)\end{array}$ & $\begin{array}{l}1.04 \\
(0.30)\end{array}$ & $\begin{array}{l}-0.63 \\
(0.53)\end{array}$ \\
\hline
\end{tabular}

This table shows the results of estimating the target capital ratio using the Blundell and Bond (1998) Generalized Method of Moments (GMM) for: (i) the baseline specification (Baseline) without the dummy variable ExcessCR; (ii) the augmented specification including a dummy variable ExcessCR (Excess control rights differentiated target); and (iii) the baseline specification estimated separately for the subsamples of banks without (ExcessControl=0) and with (ExcessControl>0) excess control rights.

Subsamples definition: A bank is classified as without excess control rights (ExcessControl=0) if (i) it is controlled by an ultimate owner with equal voting and cash-flow rights, (ii) it is widely held or (iii) if its control chain is a cross-holding. A bank is classified as with excess control rights (ExcessControl $>0$ ) if it is controlled by an ultimate owner with greater voting than cash-flow rights.

Variables definition: Tier1TA=nonrisk-based Tier 1 capital ratio; Tier1RWA=risk-based Tier 1 capital ratio; ExcessCR=dummy equal to one if voting rights are greater than cash-flow rights, and zero otherwise; $\log ($ Assets $)=$ natural logarithm of total assets; ROA=return on assets; LoanlossProv=ratio of loan loss provisions to net loans; Loans=ratio of net loans to total assets; MarketDiscipline=total long term market funding to total funding ratio; Listed=dummy equal to one if the bank is listed, and zero otherwise; GDPGrowth=real GDP (Growth Domestic Product) growth rate. Hansen test=test of exogeneity of all instruments as a group; AR2 test=second order residual autocorrelation test. Pvalues based on robust standard errors are shown in parentheses. ${ }^{*},{ }^{* *},{ }^{* * *}$ indicate statistical significance at the $10 \%, 5 \%$ and $1 \%$ levels, respectively. 
Table A5: Description of the variables used in Eq. (6) and their Summary statistics, on average, over the 2002-2010 period

\begin{tabular}{|c|c|c|c|c|c|c|}
\hline Variable & Definition and source $^{*}$ & Mean $^{* *}$ & $\begin{array}{l}\text { Standard } \\
\text { deviation }\end{array}$ & Minimum & Maximum & $\begin{array}{l}\text { Number of } \\
\text { observations }\end{array}$ \\
\hline$\Delta$ Tier1 & Annual change in Tier 1 capital less current retained earnings, all divided by average total assets ${ }^{* * *}(\%)$ & 0.41 & 1.42 & -4.73 & 10.62 & 2,204 \\
\hline RetainedEarnings & Net income less dividend paid both measured at time $t$, all divided by average total assets $(\%)$ & 0.45 & 0.85 & -3.17 & 3.23 & 2,204 \\
\hline$\Delta$ Assets & Annual change in total assets divided by average total assets $(\%)$ & 8.48 & 14.81 & -50.64 & 72.82 & 2,204 \\
\hline$\Delta$ Loans & Annual change in net loans (excluding interbank loans) divided by average total assets (\%) & 6.18 & 10.16 & -33.65 & 48.22 & 2,204 \\
\hline$\triangle \mathrm{RWA}$ & Annual change in risk-weighted assets divided by average total assets $(\%)$ & 4.60 & 13.16 & -45.88 & 70.58 & 2,204 \\
\hline \multirow[t]{2}{*}{ kSurplus } & $\begin{array}{l}\text { Absolute value of the gap between the fitted target and the lagged actual Tier } 1 \text { ratios when the bank is above its } \\
\text { target capital ratio, and zero otherwise; the target and the lagged actual Tier } 1 \text { ratios are computed based on the } \\
\text { risk-based Tier } 1 \text { ratio (\%) }\end{array}$ & 1.38 & 2.34 & 0 & 8.27 & 2,204 \\
\hline & $\begin{array}{l}\text { Absolute value of the gap between the fitted target and the lagged actual Tier } 1 \text { ratios when the bank is above its } \\
\text { target capital ratio, and zero otherwise; the target and the lagged actual Tier } 1 \text { ratios are computed based on the } \\
\text { nonrisk based Tier } 1 \text { ratio (\%) }\end{array}$ & 1.02 & 1.56 & 0 & 5.48 & 2,204 \\
\hline \multirow[t]{2}{*}{ kDeficit } & $\begin{array}{l}\text { Absolute value of the gap between the fitted target and the lagged actual Tier } 1 \text { ratios when the bank is below its } \\
\text { target capital ratio, and zero otherwise; the target and the lagged actual Tier } 1 \text { ratios are computed based on the } \\
\text { risk-based Tier } 1 \text { ratio (\%) }\end{array}$ & 1.96 & 2.61 & 0 & 10.91 & 2,204 \\
\hline & $\begin{array}{l}\text { Absolute value of the gap between the fitted target and the lagged actual Tier } 1 \text { ratios when the bank is below its } \\
\text { target capital ratio, and zero otherwise; the target and the lagged actual Tier } 1 \text { ratios are computed based on the } \\
\text { nonrisk based Tier } 1 \text { ratio (\%) }\end{array}$ & 0.97 & 1.45 & 0 & 6.34 & 2,204 \\
\hline ExcessCR & $\begin{array}{l}\text { Dummy variable equal to one if voting rights are greater than cash-flow rights, and zero otherwise. Source: } \\
\text { Bankscope, Amadeus, annual reports }\end{array}$ & 0.36 & 0.48 & 0 & 1 & 2,204 \\
\hline Deposits & Customer deposits to total assets ratio (\%) & 47.79 & 22.70 & 3.88 & 91.96 & 2,204 \\
\hline $\log ($ Age $)$ & Natural logarithm of bank age (years) & 3.73 & 1.22 & 0 & 6.29 & 2,204 \\
\hline Rescue & $\begin{array}{l}\text { Dummy variable equal to one if the bank was rescued during the } 2008 \text { financial crisis, and zero otherwise. Source: } \\
\text { Petrovic and Tutsch (2009) }\end{array}$ & 0.10 & 0.30 & 0 & 1 & 2,204 \\
\hline Merger & $\begin{array}{l}\text { Dummy variable equal to one if the bank experienced a merger-acquisition event during the sample period, and } \\
\text { zero otherwise. Source: Thomson Reuters Advanced Analytics database }\end{array}$ & 0.09 & 0.29 & 0 & 1 & 2,204 \\
\hline CrossListed & Index equal to the number of stock markets on which the bank is listed, and zero if the bank is privately owned & 1.63 & 3.18 & 0 & 16 & 2,204 \\
\hline 3MInterbankRate & 3-month interbank rate (\%). Source: Bloomberg database & 2.57 & 1.34 & 0.11 & 6.34 & 2,204 \\
\hline GDPGrowth & Real gross domestic product growth rate (\%).Source: Bloomberg database & 1.28 & 2.73 & -8.20 & 6.64 & 2,204 \\
\hline StockTraded & Value of listed shares to GDP ratio (\%). Source: World Development Indicators (The World Bank) & 77.40 & 58.28 & 0.33 & 394.60 & 2,204 \\
\hline
\end{tabular}

*All variables are retrieved from Bankscope database, unless otherwise indicated.

** Note that we report summary statistics for variables measured at time $\mathrm{t}$

**** Average total assets $=($ total assets at time $\mathrm{t}+$ total assets at time $\mathrm{t}-1) / 2$. 


\section{APPENDIX B}

Table B1. Excess control rights and capital ratio adjustment: regressions using subsamples of banks without and with excess control rights (2002-2010, GMM)

$\mathrm{y}_{\mathrm{i}, \mathrm{t}}=\alpha_{1} \mathrm{kSurplus}_{\mathrm{i}, \mathrm{t}-1}+\alpha^{\prime}{ }_{1}$ kDeficit $_{\mathrm{i}, \mathrm{t}-1}+\theta \mathrm{y}_{\mathrm{i}, \mathrm{t}-1}+\delta^{\prime} \mathrm{Z}_{\mathrm{i}, \mathrm{t}-1}+\gamma^{\prime} \mathrm{V}_{\mathrm{c}, \mathrm{t}-1}+\alpha_{0}+\omega^{\prime}$ Country $+\tau^{\prime}$ Year $+\varepsilon_{\mathrm{i}, \mathrm{t}}$

\begin{tabular}{|c|c|c|c|c|c|c|c|c|c|c|c|}
\hline \multirow{3}{*}{\multicolumn{2}{|c|}{$\begin{array}{l}\text { Dependent variable } y \\
(1)=\text { Tier1TA, }(2)=\text { Tier1RWA }\end{array}$}} & \multicolumn{4}{|c|}{ Capital adjustment } & \multicolumn{6}{|c|}{ Assets adjustment } \\
\hline & & \multicolumn{2}{|c|}{$\Delta$ Tier1 } & \multicolumn{2}{|c|}{ RetainedEarnings } & \multicolumn{2}{|c|}{$\Delta$ Assets } & \multicolumn{2}{|c|}{$\Delta$ Loans } & \multicolumn{2}{|c|}{$\Delta \mathrm{RWA}$} \\
\hline & & (1) & (2) & (1) & (2) & (1) & (2) & (1) & (2) & (1) & (2) \\
\hline \multicolumn{12}{|c|}{ Panel 1: ExcessControl=0 } \\
\hline \multicolumn{2}{|l|}{ kSurplus $\left(\alpha_{1}\right)$} & $\begin{array}{l}-0.06^{* *} \\
(0.04)\end{array}$ & $\begin{array}{l}-0.03^{*} \\
(0.08)\end{array}$ & $\begin{array}{l}-0.04^{* *} \\
(0.01)\end{array}$ & $\begin{array}{l}-0.03^{* *} \\
(0.02)\end{array}$ & $\begin{array}{l}0.75^{* *} \\
(0.04)\end{array}$ & $\begin{array}{l}0.90^{* * *} \\
(0.04)\end{array}$ & $\begin{array}{l}0.46^{* * *} \\
(0.01)\end{array}$ & $\begin{array}{l}0.50^{* *} \\
(0.05)\end{array}$ & $\begin{array}{l}0.42^{\text {** }} \\
(0.05)\end{array}$ & $\begin{array}{l}0.66^{* *} \\
(0.03)\end{array}$ \\
\hline \multicolumn{2}{|l|}{ kDeficit $\left(\alpha_{1}^{\prime}\right)$} & $\begin{array}{l}0.15^{* * *} \\
(0.00)\end{array}$ & $\begin{array}{l}0.12^{* * * *} \\
(0.00)\end{array}$ & $\begin{array}{l}0.03 \\
(0.36)\end{array}$ & $\begin{array}{l}0.04^{*} \\
(0.08)\end{array}$ & $\begin{array}{l}-0.43 \\
(0.24)\end{array}$ & $\begin{array}{l}0.17 \\
(0.59)\end{array}$ & $\begin{array}{l}-0.35 \\
(0.31)\end{array}$ & $\begin{array}{l}-0.31 \\
(0.15)\end{array}$ & $\begin{array}{l}-0.19 \\
(0.59)\end{array}$ & $\begin{array}{l}-0.47^{* *} \\
(0.03)\end{array}$ \\
\hline \multicolumn{2}{|c|}{ Control variables } & Yes & Yes & Yes & Yes & Yes & Yes & Yes & Yes & Yes & Yes \\
\hline \multicolumn{2}{|c|}{ Number of observations } & 1,416 & 1,416 & 1,416 & 1,416 & 1,416 & 1,416 & 1,416 & 1,416 & 1,416 & 1,416 \\
\hline \multicolumn{2}{|c|}{ Number of banks } & 236 & 236 & 236 & 236 & 236 & 236 & 236 & 236 & 236 & 236 \\
\hline Hansen test: & $\begin{array}{l}\text { Statistic } \\
\text { P-value }\end{array}$ & $\begin{array}{l}98.05 \\
(0.14)\end{array}$ & $\begin{array}{l}95.15 \\
(0.16)\end{array}$ & $\begin{array}{l}98.40 \\
(0.15)\end{array}$ & $\begin{array}{l}93.17 \\
(0.18)\end{array}$ & $\begin{array}{l}99.63 \\
(0.12)\end{array}$ & $\begin{array}{l}92.30 \\
(0.19)\end{array}$ & $\begin{array}{l}98.19 \\
(0.15)\end{array}$ & $\begin{array}{l}92.06 \\
(0.14)\end{array}$ & $\begin{array}{l}95.54 \\
(0.15)\end{array}$ & $\begin{array}{l}97.27 \\
(0.15)\end{array}$ \\
\hline AR2 test: & $\begin{array}{l}\text { Statistic } \\
\text { P-value }\end{array}$ & $\begin{array}{l}0.15 \\
(0.86) \\
\end{array}$ & $\begin{array}{l}-0.12 \\
(0.89) \\
\end{array}$ & $\begin{array}{l}-0.17 \\
(0.86) \\
\end{array}$ & $\begin{array}{l}0.16 \\
(0.80)\end{array}$ & $\begin{array}{l}0.50 \\
(0.62)\end{array}$ & $\begin{array}{l}0.54 \\
(0.59)\end{array}$ & $\begin{array}{l}-0.12 \\
(0.90) \\
\end{array}$ & $\begin{array}{l}-0.06 \\
(0.95) \\
\end{array}$ & $\begin{array}{l}1.08 \\
(0.28) \\
\end{array}$ & $\begin{array}{l}1.20 \\
(0.23)\end{array}$ \\
\hline \multicolumn{2}{|c|}{ Fitted target (\%):Mean } & 7.04 & 11.70 & 7.04 & 11.70 & 7.04 & 11.70 & 7.04 & 11.70 & 7.04 & 11.70 \\
\hline & Maximum & 15.73 & 24.46 & 15.73 & 24.46 & 15.73 & 24.46 & 15.73 & 24.46 & 15.73 & 24.46 \\
\hline & Minimum & 1.61 & 4.89 & 1.61 & 4.89 & 1.61 & 4.89 & 1.61 & 4.89 & 1.61 & 4.89 \\
\hline \multicolumn{12}{|c|}{ Panel 2: ExcessControl>0 } \\
\hline \multicolumn{2}{|l|}{ kSurplus $\left(\alpha_{1}\right)$} & $\begin{array}{l}-0.14^{* *} \\
(0.01)\end{array}$ & $\begin{array}{l}-0.07^{* *} \\
(0.04)\end{array}$ & $\begin{array}{l}-0.04 \\
(0.28)\end{array}$ & $\begin{array}{l}-0.03 \\
(0.14)\end{array}$ & $\begin{array}{l}0.40 \\
(0.39)\end{array}$ & $\begin{array}{l}0.39 \\
(0.86)\end{array}$ & $\begin{array}{l}0.27 \\
(0.35)\end{array}$ & $\begin{array}{l}0.26 \\
(0.65)\end{array}$ & $\begin{array}{l}0.23 \\
(0.39)\end{array}$ & $\begin{array}{l}0.38 \\
(0.17)\end{array}$ \\
\hline \multicolumn{2}{|l|}{ kDeficit $\left(\alpha^{\prime}{ }_{1}\right)$} & $\begin{array}{l}0.05 \\
(0.25) \\
\end{array}$ & $\begin{array}{l}0.02 \\
(0.36) \\
\end{array}$ & $\begin{array}{l}0.07^{* *} \\
(0.03) \\
\end{array}$ & $\begin{array}{l}0.04^{* *} \\
(0.03) \\
\end{array}$ & $\begin{array}{l}-0.74^{* * *} \\
(0.03) \\
\end{array}$ & $\begin{array}{l}-0.74^{* * *} \\
(0.03) \\
\end{array}$ & $\begin{array}{l}-0.60^{* * *} \\
(0.05) \\
\end{array}$ & $\begin{array}{l}-0.75^{\text {** }} \\
(0.02) \\
\end{array}$ & $\begin{array}{l}-0.50^{*} \\
(0.09) \\
\end{array}$ & $\begin{array}{l}-0.65^{* *} \\
(0.02) \\
\end{array}$ \\
\hline \multicolumn{2}{|c|}{ Control variables } & Yes & Yes & Yes & Yes & Yes & Yes & Yes & Yes & Yes & Yes \\
\hline \multicolumn{2}{|c|}{ Number of observations } & 788 & 788 & 788 & 788 & 788 & 788 & 788 & 788 & 788 & 788 \\
\hline \multicolumn{2}{|c|}{ Number of banks } & 154 & 154 & 154 & 154 & 154 & 154 & 154 & 154 & 154 & 154 \\
\hline Hansen test: & $\begin{array}{l}\text { Statistic } \\
\text { P-value }\end{array}$ & $\begin{array}{l}107.63 \\
(0.14)\end{array}$ & $\begin{array}{l}93.39 \\
(0.23)\end{array}$ & $\begin{array}{l}92.13 \\
(0.25)\end{array}$ & $\begin{array}{l}84.93 \\
(0.45)\end{array}$ & $\begin{array}{l}96.90 \\
(0.16)\end{array}$ & $\begin{array}{l}97.53 \\
(0.15)\end{array}$ & $\begin{array}{l}89.19 \\
(0.33)\end{array}$ & $\begin{array}{l}99.63 \\
(0.12)\end{array}$ & $\begin{array}{l}93.56 \\
(0.22)\end{array}$ & $\begin{array}{l}93.87 \\
(0.22)\end{array}$ \\
\hline AR2 test: & $\begin{array}{l}\text { Statistic } \\
\text { P-value }\end{array}$ & $\begin{array}{l}1.17 \\
(0.24)\end{array}$ & $\begin{array}{l}1.12 \\
(0.26) \\
\end{array}$ & $\begin{array}{l}-0.33 \\
(0.74)\end{array}$ & $\begin{array}{l}-0.24 \\
(0.81)\end{array}$ & $\begin{array}{l}1.21 \\
(0.23)\end{array}$ & $\begin{array}{l}1.34 \\
(0.18)\end{array}$ & $\begin{array}{l}1.06 \\
(0.24)\end{array}$ & $\begin{array}{l}1.10 \\
(0.24)\end{array}$ & $\begin{array}{l}1.14 \\
(0.18)\end{array}$ & $\begin{array}{l}1.60 \\
(0.11)\end{array}$ \\
\hline \multirow[t]{3}{*}{ Fitted target (} & : Mean & 6.49 & 10.14 & 6.49 & 10.14 & 6.49 & 10.14 & 6.49 & 10.14 & 6.49 & 10.14 \\
\hline & Maximum & 12.67 & 19.76 & 12.67 & 19.76 & 12.67 & 19.76 & 12.67 & 19.76 & 12.67 & 19.76 \\
\hline & Minimum & 2.31 & 5.98 & 2.31 & 5.98 & 2.31 & 5.98 & 2.31 & 5.98 & 2.31 & 5.98 \\
\hline
\end{tabular}

Subsamples definition: A bank is classified as without excess control rights (ExcessControl=0) if (i) it is controlled by an ultimate owner with equal voting and cash-flow rights, (ii) it is widely held or (iii) if its control chain is a cross-holding. A bank is classified as with excess control rights (ExcessControl $>0$ ) if it is controlled by an ultimate owner with greater voting than cash-flow rights.

Variables definition: $\Delta$ Tier1=annual change in Tier 1 capital less current retained earnings/average assets; RetainedEarnings=current net income less current dividend payment/average assets; $\Delta$ Assets=annual change in total assets/average assets; $\Delta$ Loans $=$ annual change in net loans/average assets; $\Delta \mathrm{RWA}=$ annual change in risk-weighted assets/average assets; average assets $=\left(\right.$ total assets $_{\mathrm{t}}+$ total $\left._{\text {assets }} \mathrm{t}_{\mathrm{t}}\right) / 2$; Tier1TA and Tier1RWA are respectively nonrisk- and risk-based Tier 1 capital ratios; kSurplus=absolute value of the gap between the target and the lagged Tier 1 ratios when the bank is above its target, and zero otherwise; kDeficit=absolute value of the gap between the target and the lagged Tier 1 ratios when the bank is below its target, and zero otherwise. The regressions contain the same control variables (except ExcessCR) as in Table 4 (see their definition in Table A5 in Appendix A). Country and Year dummies are included but not reported. Detailed results are available on request. Hansen test=test of exogeneity of all instruments as a group; AR2 test=second order residual autocorrelation test. P-values based on robust standard errors are shown in parentheses. ${ }^{*},{ }^{* *}$ and ${ }^{* * * *}$ indicate statistical significance at the $10 \%, 5 \%$ and $1 \%$ levels respectively. 
Table B2: Excess control rights and capital ratio adjustment (2002-2010, GMM)

$$
\begin{aligned}
\mathrm{y}_{\mathrm{i}, \mathrm{t}} & =\left(\alpha_{1}+\beta_{1} \text { ExcessCR }\right) \text { kSurplus }_{\mathrm{i}, \mathrm{t}-1}+\left(\alpha^{\prime}{ }_{1}+\beta^{\prime}{ }_{1} \text { ExcessCR } \mathrm{kDeficit}_{\mathrm{i}, \mathrm{t}-1}+\theta \mathrm{y}_{\mathrm{i}, \mathrm{t}-1}+\delta^{\prime} \mathrm{Z}_{\mathrm{i}, \mathrm{t}-1}+\gamma^{\prime} \mathrm{V}_{\mathrm{c}, \mathrm{t}-1}\right. \\
& +\alpha_{0}+\omega^{\prime} \text { Country }+\tau^{\prime} \text { Year }+\varepsilon_{\mathrm{i}, \mathrm{t}}
\end{aligned}
$$

\begin{tabular}{|c|c|c|c|c|c|}
\hline & \multicolumn{2}{|c|}{ Capital adjustment } & \multicolumn{3}{|c|}{ Assets adjustment } \\
\hline Dependent variable y & $\Delta$ Tier1 & RetainedEarnings & $\Delta$ Assets & $\Delta$ Loans & $\Delta \mathrm{RWA}$ \\
\hline$(1)=$ Tier1TA, $(2)=$ Tier1RWA & (1) (2) & (1) (2) & (1) (2) & (1) (2) & $(1)$ \\
\hline
\end{tabular}

\begin{tabular}{|c|c|c|c|c|c|c|c|c|c|c|c|}
\hline \multicolumn{2}{|c|}{ kSurplus $\left(\alpha_{1}\right)$} & $\begin{array}{l}-0.06^{*} \\
(0.07)\end{array}$ & $\begin{array}{l}-0.04^{*} \\
(0.08)\end{array}$ & $\begin{array}{l}-0.05^{* *} \\
(0.02)\end{array}$ & $\begin{array}{l}-0.04^{* *} \\
(0.03)\end{array}$ & $\begin{array}{l}0.77^{* *} \\
(0.04)\end{array}$ & $\begin{array}{l}0.90^{* *} \\
(0.03)\end{array}$ & $\begin{array}{l}0.45^{* * *} \\
(0.02)\end{array}$ & $\begin{array}{l}0.54^{* * *} \\
(0.02)\end{array}$ & $\begin{array}{l}0.48^{* * *} \\
(0.02)\end{array}$ & $\begin{array}{l}0.70^{* * *} \\
(0.02)\end{array}$ \\
\hline \multicolumn{2}{|c|}{ ExcessCR $\times$ kSurplus $\left(\beta_{1}\right)$} & $\begin{array}{l}-0.08 \\
(0.43)\end{array}$ & $\begin{array}{l}-0.02 \\
(0.70)\end{array}$ & $\begin{array}{l}0.03 \\
(0.47)\end{array}$ & $\begin{array}{l}0.01 \\
(0.79)\end{array}$ & $\begin{array}{l}-0.36^{* *} \\
(0.04)\end{array}$ & $\begin{array}{l}-0.45^{* *} \\
(0.03)\end{array}$ & $\begin{array}{l}-0.19^{*} \\
(0.06)\end{array}$ & $\begin{array}{l}-0.30^{* *} \\
(0.04)\end{array}$ & $\begin{array}{l}-0.28^{*} \\
(0.07)\end{array}$ & $\begin{array}{l}-0.37^{*} \\
(0.07)\end{array}$ \\
\hline \multicolumn{2}{|c|}{$\operatorname{kDeficit}\left(\alpha_{1}^{\prime}\right)$} & $\begin{array}{l}0.16^{* *} \\
(0.01)\end{array}$ & $\begin{array}{l}0.12^{* * *} \\
(0.01)\end{array}$ & $\begin{array}{l}0.03 \\
(0.41)\end{array}$ & $\begin{array}{l}0.03 \\
(0.19)\end{array}$ & $\begin{array}{l}-0.36 \\
(0.20)\end{array}$ & $\begin{array}{l}0.06 \\
(0.89)\end{array}$ & $\begin{array}{l}-0.35 \\
(0.29)\end{array}$ & $\begin{array}{l}-0.38 \\
(0.13)\end{array}$ & $\begin{array}{l}-0.22 \\
(0.51)\end{array}$ & $\begin{array}{l}-0.60^{* * *} \\
(0.01)\end{array}$ \\
\hline \multicolumn{2}{|c|}{ ExcessCR $\times$ kDeficit $\left(\beta_{1}^{\prime}\right)$} & $\begin{array}{l}-0.11^{*} \\
(0.08)\end{array}$ & $\begin{array}{l}-0.09^{* *} \\
(0.04)\end{array}$ & $\begin{array}{l}0.04 \\
(0.37)\end{array}$ & $\begin{array}{l}0.04^{* *} \\
(0.07)\end{array}$ & $\begin{array}{l}-0.40^{* *} \\
(0.03)\end{array}$ & $\begin{array}{l}-0.76^{* *} \\
(0.03)\end{array}$ & $\begin{array}{l}-0.26^{* *} \\
(0.03)\end{array}$ & $\begin{array}{l}-0.25^{* *} \\
(0.02)\end{array}$ & $\begin{array}{l}-0.32^{*} \\
(0.06)\end{array}$ & $\begin{array}{l}-0.04 \\
(0.49)\end{array}$ \\
\hline \multicolumn{2}{|c|}{ Control variables } & Yes & Yes & Yes & Yes & Yes & Yes & Yes & Yes & Yes & Yes \\
\hline \multicolumn{2}{|c|}{ Number of observations } & $\begin{array}{l}2,204 \\
341 \\
\end{array}$ & $\begin{array}{l}2,204 \\
341 \\
\end{array}$ & $\begin{array}{l}2,204 \\
341 \\
\end{array}$ & $\begin{array}{l}2,204 \\
341 \\
\end{array}$ & $\begin{array}{l}2,204 \\
341 \\
\end{array}$ & $\begin{array}{l}2,204 \\
341 \\
\end{array}$ & $\begin{array}{l}2,204 \\
341 \\
\end{array}$ & $\begin{array}{l}2,204 \\
341 \\
\end{array}$ & $\begin{array}{l}2,204 \\
341 \\
\end{array}$ & $\begin{array}{l}2,204 \\
341 \\
\end{array}$ \\
\hline Hansen test & $\begin{array}{l}\text { Statistic } \\
\text { P-value }\end{array}$ & $\begin{array}{l}189.99 \\
(0.10)\end{array}$ & $\begin{array}{l}179.18 \\
(0.20)\end{array}$ & $\begin{array}{l}182.24 \\
(0.16)\end{array}$ & $\begin{array}{l}183.11 \\
(0.16)\end{array}$ & $\begin{array}{l}179.71 \\
(0.19)\end{array}$ & $\begin{array}{l}181.85 \\
(0.16)\end{array}$ & $\begin{array}{l}186.42 \\
(0.11)\end{array}$ & $\begin{array}{l}187.86 \\
(0.10)\end{array}$ & $\begin{array}{l}181.80 \\
(0.16)\end{array}$ & $\begin{array}{l}165.23 \\
(0.46)\end{array}$ \\
\hline AR2 test: & $\begin{array}{l}\text { Statistic } \\
\text { P-value }\end{array}$ & $\begin{array}{l}0.08 \\
(0.94) \\
\end{array}$ & $\begin{array}{l}-0.06 \\
(0.95) \\
\end{array}$ & $\begin{array}{l}-0.02 \\
(0.89) \\
\end{array}$ & $\begin{array}{l}0.05 \\
(0.96) \\
\end{array}$ & $\begin{array}{l}1.18 \\
(0.24) \\
\end{array}$ & $\begin{array}{l}1.16 \\
(0.25) \\
\end{array}$ & $\begin{array}{l}0.87 \\
(0.38) \\
\end{array}$ & $\begin{array}{l}0.70 \\
(0.49) \\
\end{array}$ & $\begin{array}{l}1.06 \\
(0.14) \\
\end{array}$ & $\begin{array}{l}1.09 \\
(0.15) \\
\end{array}$ \\
\hline Fitted targe & $\begin{array}{l}\text { 6): Mean } \\
\text { Maximum } \\
\text { Minimum }\end{array}$ & $\begin{array}{l}6.97 \\
15.10 \\
1.15 \\
\end{array}$ & $\begin{array}{l}10.88 \\
21.49 \\
4.36 \\
\end{array}$ & $\begin{array}{l}6.97 \\
15.10 \\
1.15 \\
\end{array}$ & $\begin{array}{l}10.88 \\
21.49 \\
4.36 \\
\end{array}$ & $\begin{array}{l}6.97 \\
15.10 \\
1.15 \\
\end{array}$ & $\begin{array}{l}10.88 \\
21.49 \\
4.36 \\
\end{array}$ & $\begin{array}{l}6.97 \\
15.10 \\
1.15 \\
\end{array}$ & $\begin{array}{l}10.88 \\
21.49 \\
4.36 \\
\end{array}$ & $\begin{array}{l}6.97 \\
15.10 \\
1.15 \\
\end{array}$ & $\begin{array}{l}10.88 \\
21.49 \\
4.36 \\
\end{array}$ \\
\hline \multicolumn{2}{|c|}{$\begin{array}{l}\alpha_{1}+\beta_{1} \\
\text { Wald test (P-value) }\end{array}$} & $\begin{array}{l}-0.14^{* *} \\
(0.03)\end{array}$ & $\begin{array}{l}-0.06^{* *} \\
(0.02)\end{array}$ & $\begin{array}{l}-0.02 \\
(0.27)\end{array}$ & $\begin{array}{l}-0.03^{*} \\
(0.08)\end{array}$ & $\begin{array}{l}0.41 \\
(0.23)\end{array}$ & $\begin{array}{l}0.45 \\
(0.32)\end{array}$ & $\begin{array}{l}0.26 \\
(0.42)\end{array}$ & $\begin{array}{l}0.24 \\
(0.75)\end{array}$ & $\begin{array}{l}0.20 \\
(0.50)\end{array}$ & $\begin{array}{l}0.33 \\
(0.15)\end{array}$ \\
\hline \multicolumn{2}{|c|}{$\begin{array}{l}\alpha_{1}^{\prime}+\beta_{1}^{\prime} \\
\text { Wald test (P-value) }\end{array}$} & $\begin{array}{l}0.05 \\
(0.12)\end{array}$ & $\begin{array}{l}0.03 \\
(0.25)\end{array}$ & $\begin{array}{l}0.07^{* *} \\
(0.04)\end{array}$ & $\begin{array}{l}0.07^{* * *} \\
(0.04)\end{array}$ & $\begin{array}{l}-0.76^{* *} \\
(0.04)\end{array}$ & $\begin{array}{l}-0.70^{* *} \\
(0.03)\end{array}$ & $\begin{array}{l}-0.61^{* *} \\
(0.03)\end{array}$ & $\begin{array}{l}-0.63^{* *} \\
(0.02)\end{array}$ & $\begin{array}{l}-0.54^{*} \\
(0.09)\end{array}$ & $\begin{array}{l}-0.64^{* *} \\
(0.03)\end{array}$ \\
\hline
\end{tabular}

Panel 1: Fitted values of the target are obtained using a perfect adjustment model

\begin{tabular}{|c|c|c|c|c|c|c|c|c|c|c|c|}
\hline \multicolumn{2}{|l|}{ kSurplus $\left(\alpha_{1}\right)$} & $\begin{array}{l}-0.06^{*} \\
(0.06)\end{array}$ & $\begin{array}{l}-0.04^{*} \\
(0.07)\end{array}$ & $\begin{array}{l}-0.06^{* *} \\
(0.02)\end{array}$ & $\begin{array}{l}-0.05^{* *} \\
(0.04)\end{array}$ & $\begin{array}{l}0.76^{* *} \\
(0.04)\end{array}$ & $\begin{array}{l}0.88^{* *} \\
(0.04)\end{array}$ & $\begin{array}{l}0.47^{* * *} \\
(0.03)\end{array}$ & $\begin{array}{l}0.47^{* *} \\
(0.04)\end{array}$ & $\begin{array}{l}0.53^{* *} \\
(0.02)\end{array}$ & $\begin{array}{l}0.64^{* *} \\
(0.03)\end{array}$ \\
\hline \multicolumn{2}{|c|}{ ExcessCR $\times$ kSurplus $\left(\beta_{1}\right)$} & $\begin{array}{l}-0.07 \\
(0.34)\end{array}$ & $\begin{array}{l}-0.04 \\
(0.29)\end{array}$ & $\begin{array}{l}0.03 \\
(0.50)\end{array}$ & $\begin{array}{l}0.02 \\
(0.78)\end{array}$ & $\begin{array}{l}-0.42^{* *} \\
(0.03)\end{array}$ & $\begin{array}{l}-0.48^{*} \\
(0.07)\end{array}$ & $\begin{array}{l}-0.20^{*} \\
(0.06)\end{array}$ & $\begin{array}{l}-0.23^{* *} \\
(0.04)\end{array}$ & $\begin{array}{l}-0.35^{*} \\
(0.06)\end{array}$ & $\begin{array}{l}-0.30^{*} \\
(0.06)\end{array}$ \\
\hline \multicolumn{2}{|l|}{ kDeficit $\left(\alpha_{1}^{\prime}\right)$} & $\begin{array}{l}0.15^{* *} \\
(0.03)\end{array}$ & $\begin{array}{l}0.10^{* * *} \\
(0.00)\end{array}$ & $\begin{array}{l}0.04 \\
(0.13)\end{array}$ & $\begin{array}{l}0.04^{*} \\
(0.10)\end{array}$ & $\begin{array}{l}-0.34 \\
(0.24)\end{array}$ & $\begin{array}{l}0.08 \\
(0.82)\end{array}$ & $\begin{array}{l}-0.36 \\
(0.21)\end{array}$ & $\begin{array}{l}-0.36 \\
(0.11)\end{array}$ & $\begin{array}{l}-0.23 \\
(0.52)\end{array}$ & $\begin{array}{l}-0.63^{* *} \\
(0.02)\end{array}$ \\
\hline \multicolumn{2}{|c|}{ ExcessCR $\times$ kDeficit $\left(\beta_{1}^{\prime}\right)$} & $\begin{array}{l}-0.11^{*} \\
(0.05)\end{array}$ & $\begin{array}{l}-0.06^{*} \\
(0.07)\end{array}$ & $\begin{array}{l}0.04^{* *} \\
(0.03)\end{array}$ & $\begin{array}{l}0.02^{*} \\
(0.08)\end{array}$ & $\begin{array}{l}-0.37^{* *} \\
(0.02)\end{array}$ & $\begin{array}{l}-0.79^{* *} \\
(0.02)\end{array}$ & $\begin{array}{l}-0.27^{* * *} \\
(0.03)\end{array}$ & $\begin{array}{l}-0.30^{* *} \\
(0.03)\end{array}$ & $\begin{array}{l}-0.29^{*} \\
(0.07) \\
\end{array}$ & $\begin{array}{l}-0.02 \\
(0.28)\end{array}$ \\
\hline \multicolumn{2}{|c|}{ Control variables } & Yes & Yes & Yes & Yes & Yes & Yes & Yes & Yes & Yes & Yes \\
\hline \multicolumn{2}{|c|}{$\begin{array}{l}\text { Number of observations } \\
\text { Number of banks }\end{array}$} & $\begin{array}{l}1,705 \\
281\end{array}$ & $\begin{array}{l}1,705 \\
281\end{array}$ & $\begin{array}{l}1,705 \\
281\end{array}$ & $\begin{array}{l}1,705 \\
281\end{array}$ & $\begin{array}{l}1,705 \\
281\end{array}$ & $\begin{array}{l}1,705 \\
281\end{array}$ & $\begin{array}{l}1,705 \\
281\end{array}$ & $\begin{array}{l}1,705 \\
281\end{array}$ & $\begin{array}{l}1,705 \\
281\end{array}$ & $\begin{array}{l}1,705 \\
281\end{array}$ \\
\hline Hansen test: & $\begin{array}{l}\text { Statistic } \\
\text { P-value } \\
\text { Statistic } \\
\text { P-value }\end{array}$ & $\begin{array}{l}186.49 \\
(0.14) \\
-0.13 \\
(0.89) \\
\end{array}$ & $\begin{array}{l}184.17 \\
(0.13) \\
-0.09 \\
(0.93) \\
\end{array}$ & $\begin{array}{l}181.45 \\
(0.10) \\
-0.17 \\
(0.86) \\
\end{array}$ & $\begin{array}{l}181.39 \\
(0.17) \\
0.11 \\
(0.90) \\
\end{array}$ & $\begin{array}{l}177.27 \\
(0.23) \\
0.36 \\
(0.72) \\
\end{array}$ & $\begin{array}{l}173.45 \\
(0.29) \\
0.46 \\
(0.65) \\
\end{array}$ & $\begin{array}{l}179.24 \\
(0.20) \\
0.11 \\
(0.90) \\
\end{array}$ & $\begin{array}{l}183.85 \\
(0.16) \\
0.12 \\
(0.91) \\
\end{array}$ & $\begin{array}{l}182.56 \\
(0.15) \\
1.00 \\
(0.15) \\
\end{array}$ & $\begin{array}{l}163.21 \\
(0.50) \\
0.95 \\
(0.15) \\
\end{array}$ \\
\hline Fitted target & $\begin{array}{l}\text { ):Mean } \\
\text { Maximum } \\
\text { Minimum }\end{array}$ & $\begin{array}{l}6.89 \\
14.66 \\
1.15\end{array}$ & $\begin{array}{l}11.34 \\
23.60 \\
4.17\end{array}$ & $\begin{array}{l}6.89 \\
14.66 \\
1.15\end{array}$ & $\begin{array}{l}11.34 \\
23.60 \\
4.17\end{array}$ & $\begin{array}{l}6.89 \\
14.66 \\
1.15\end{array}$ & $\begin{array}{l}11.34 \\
23.60 \\
4.17\end{array}$ & $\begin{array}{l}6.89 \\
14.66 \\
1.15\end{array}$ & $\begin{array}{l}11.34 \\
23.60 \\
4.17\end{array}$ & $\begin{array}{l}6.89 \\
14.66 \\
1.15\end{array}$ & $\begin{array}{l}11.34 \\
23.60 \\
4.17\end{array}$ \\
\hline \multicolumn{2}{|c|}{$\begin{array}{l}\alpha_{1}+\beta_{1} \\
\text { Wald test (P-value) }\end{array}$} & $\begin{array}{l}-0.13^{* *} \\
(0.01)\end{array}$ & $\begin{array}{l}-0.08^{* *} \\
(0.04)\end{array}$ & $\begin{array}{l}-0.03 \\
(0.23)\end{array}$ & $\begin{array}{l}-0.03^{*} \\
(0.07)\end{array}$ & $\begin{array}{l}0.34 \\
(0.36)\end{array}$ & $\begin{array}{l}0.40 \\
(0.60)\end{array}$ & $\begin{array}{l}0.27 \\
(0.52)\end{array}$ & $\begin{array}{l}0.24 \\
(0.54)\end{array}$ & $\begin{array}{l}0.18 \\
(0.50)\end{array}$ & $\begin{array}{l}0.34 \\
(0.18)\end{array}$ \\
\hline \multicolumn{2}{|c|}{$\begin{array}{l}\alpha_{1}^{\prime}+\beta_{1}^{\prime} \\
\text { Wald test (P-value) }\end{array}$} & $\begin{array}{l}0.04 \\
(0.27)\end{array}$ & $\begin{array}{l}0.04 \\
(0.15)\end{array}$ & $\begin{array}{l}0.08^{* *} \\
(0.02)\end{array}$ & $\begin{array}{l}0.06^{* *} \\
(0.04)\end{array}$ & $\begin{array}{l}-0.71^{* *} \\
(0.04)\end{array}$ & $\begin{array}{l}-0.71^{* *} \\
(0.01)\end{array}$ & $\begin{array}{l}-0.63^{* *} \\
(0.04)\end{array}$ & $\begin{array}{l}-0.66^{* *} \\
(0.01)\end{array}$ & $\begin{array}{l}-0.52^{* * *} \\
(0.04)\end{array}$ & $\begin{array}{l}-0.65^{* *} \\
(0.02)\end{array}$ \\
\hline
\end{tabular}

Panel2: Excluding banks controlled by more than one large ultimate shareholder

Variables definition: $\Delta$ Tier1=annual change in Tier 1 capital less current retained earnings/average assets; RetainedEarnings $=$ current net income less current dividend payment/average assets; $\Delta$ Assets=annual change in total assets/average assets; $\Delta$ Loans=annual change in net loans/average assets; $\Delta \mathrm{RWA}=$ annual change in risk-weighted assets/average assets; average assets=(total assets $_{\mathrm{t}}+$ total assets $\left.\mathrm{t}_{\mathrm{t}-1}\right) / 2$; Tier1TA and Tier1RWA are respectively nonrisk- and risk-based Tier 1 capital ratios; kSurplus=absolute value of the gap between the target and the lagged Tier 1 ratios when the bank is above its target, and zero otherwise; ExcessCR=dummy equal to one if control rights are greater than cash-flow rights, and zero otherwise; kDeficit=absolute value of the gap between the target and the lagged Tier 1 ratios when the bank is below its target, and zero otherwise. The regressions contain the same control variables as in Table 4 (see their definition in Table A5 in Appendix A). Country and Year dummies are included but not reported. Detailed results are available on request. Hansen test=test of exogeneity of all instruments as a group; AR2 test=second order residual autocorrelation test. P-values based on robust standard errors are shown in parentheses. ${ }^{*},{ }^{* *}$ and ${ }^{* * *}$ indicate statistical significance at the $10 \%, 5 \%$ and $1 \%$ levels respectively. 
Table B3: Excess control rights and capital ratio adjustment (2002-2010, GMM)

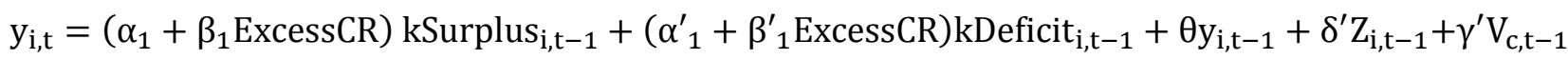

$$
\begin{aligned}
& +\alpha_{0}+\omega^{\prime} \text { Country }+\tau^{\prime} \text { Year }+\varepsilon_{i, \mathrm{t}}
\end{aligned}
$$

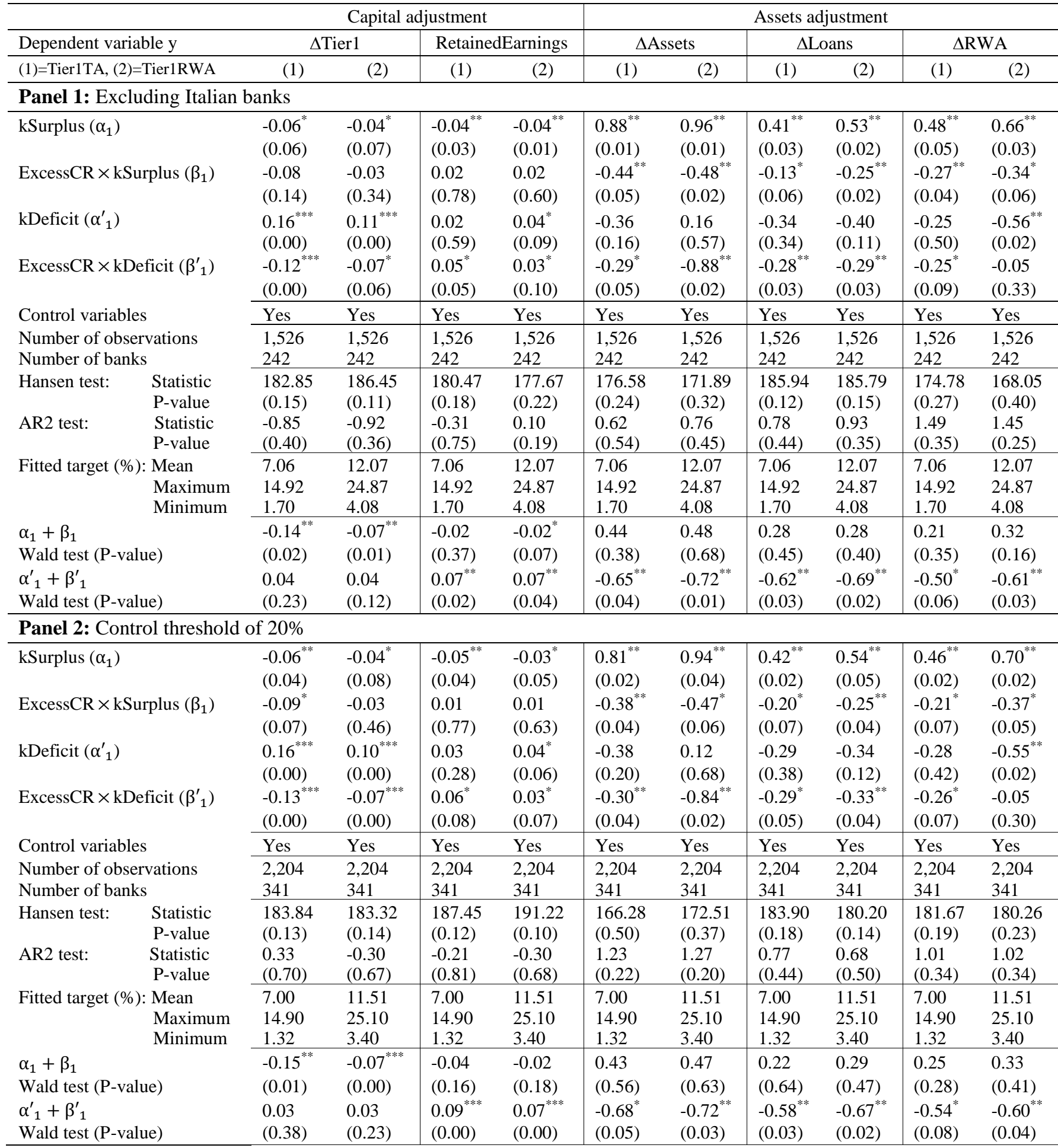

Variables definition: $\Delta$ Tier1=annual change in Tier 1 capital less current retained earnings/average assets; RetainedEarnings=current net income less current dividend payment/average assets; $\Delta$ Assets=annual change in total assets/average assets; $\Delta$ Loans $=$ annual change in net loans/average assets; $\Delta \mathrm{RWA}=$ annual change in risk-weighted assets/average assets; average assets $=\left(\right.$ total $_{\text {assets }}+$ total $_{\mathrm{t}}$ assets $\left._{\mathrm{t}-1}\right) / 2$; Tier1TA and Tier1RWA are respectively nonrisk- and risk-based Tier 1 capital ratios; kSurplus=absolute value of the gap between the target and the lagged Tier 1 ratios when the bank is above its target, and zero otherwise; ExcessCR=dummy equal to one if control rights are greater than cash-flow rights, and zero otherwise; kDeficit=absolute value of the gap between the target and the lagged Tier 1 ratios when the bank is below its target, and zero otherwise. The regressions contain the same control variables as in Table 4 (see their definition in Table A5 in Appendix A). Country and Year dummies are included but not reported. Detailed results are available on request. Hansen test=test of exogeneity of all instruments as a group; AR2 test=second order residual autocorrelation test. P-values based on robust standard errors are shown in parentheses. ${ }^{*},{ }^{* *}$ and ${ }^{* * *}$ indicate statistical significance at the $10 \%, 5 \%$ and $1 \%$ levels respectively. 